\title{
THE MIDDLE-DNIESTER CULTURAL CONTACT AREA OF EARLY METAL AGE SOCIETIES. THE FRONTIER OF PONTIC AND BALTIC DRAINAGE BASINS IN THE 4TH/3RD-2ND MILLENNIUM BC.
}

\begin{abstract}
The paper discusses the taxonomy and autogenesis of the cycle of early 'barrow cultures' developed by the local communities of the Middle Dniester Area or, in a broader comparative context, the north-western Black Sea Coast, in the 4th/3rd-2nd millennium BC. The purpose of the study is to conduct an analytical and conceptual entry point to the research questions of the Dniester Contact Area, specifically the contacts between autochthonous 'Late Eneolithic' communities (Yamnaya, Catacomb and Babyno cultures) and incoming communities from the Baltic basin. The discussion of these cultures continues in other papers presented in this volume of Baltic-Pontic Studies.
\end{abstract}

ABSTRACT

Key words: Eneolithic, Yamnaya, Catacomb and Babyno cultures, Dniester, north-western Black Sea Coast

The Middle Dniester Area, situated on the south-western frontier of Podolia (abutting on Bessarabia - Moldavia) is one of the two currently recognizable contact areas of the societies of Late Eneolithic and 'Early Bronze' cultures identified with the Pontic area and 'Late Neolithic' (Eneolithicized) ones traceable to the

\footnotetext{
* Institute of Archaeology National Academy of Science of Ukraine; Heroyiv Stalingrada 12, 04210 Kyiv, Ukraine; svi1956@gmail.com

** Zaporizhya National University; Zhukovskogo Street 66, 69063 Zaporizhzhya, Ukraine; gent51 @ mail.ru
} 
Baltic drainage basin [see Klochko, Kośko 2013]. ${ }^{1}$ The present paper attempts to give a 'taxonomic picture' of the contact area in the 4th/3rd-2nd millennium BC from the perspective of local, mostly Pontic, societies.

A motivation for this approach is provided by the conclusions of the Yampil Programme: interdisciplinary field investigations of the north-westernmost complex of barrow cemeteries on the Dniester, associated with the societies of Pontic Eneolithic and 'Early Bronze' cultures [Kośko et al. (Eds) 2014]². The major research inspirations came in this case from the innovative chronometric (radiocarbon) determinations and new possibilities for topogenetic analyses offered by the 'Yampil' diagnostic corpus of sources [Goslar et al. 2015].

Mentioned in the title, the prologue of the Bronze Age embraces four levels of barrow taxa related to the Eneolithic: Yamnaya culture (YC), Catacomb culture (CC) and Babyno culture (BC). The authors' intention is to outline the research scope for the correspondence analysis of the societies in question and those of the cultural area of the Baltic drainage basin. Specifically, this applies for the most part to the populations of the Globular Amphora culture (GAC) and Corded Ware culture (CWC) [see Ivanova et al. 2015].

\section{LATE ENEOLITHIC AND EARLY BRONZE AGE}

IN THE MIDDLE DNIESTER AREA

The Late Eneolithic/Early Bronze Age on the northern Black Sea Coast is traditionally held to embrace the sites that are dated between 3400/3200 and 2750 BC or to stage CII on the taxonomic chronological scale of the Tripolye culture [Videiko 1999; Rassamakin 2004]. It is this time interval that researchers believe to have coincided with the dawn of the Bronze Age (ca. 3200 BC) [Otroshchenko et al. 2008: 219]. It follows that there co-existed cultures, formally contemporaneous, but belonging to different ages. This is an illustration of the fact that prehistoric societies not only developed unevenly but also that periods distinguished by archaeologists reflect, apart from chronology, the evolution of societies as well.

The sites dating to the Late Eneolithic and Early Bronze Age ${ }^{3}$ are unevenly distributed throughout the north-western Black Sea Coast. Some were recorded

1 To the other contact area - the drainage basin of the Ros' and middle Dnieper rivers (Podolia on the Dniester) - a separate study will be devoted and published as BPS vol. 22 .

2 The programme was carried out in cooperation by the Institute of Prehistory, Adam Mickiewicz University in Poznan, and the Institute of Archaeology, Ukrainian NAS in Kyiv.

3 This paper uses two perspectives on the Early Bronze period: conventional, considering it one in the sequence of three periods (early, middle and late) and essential, one of 'Early Bronze cultures', such as YC, CC, and $\mathrm{BC}$, i.e. cultural units corresponding to the period of composite metal use. 


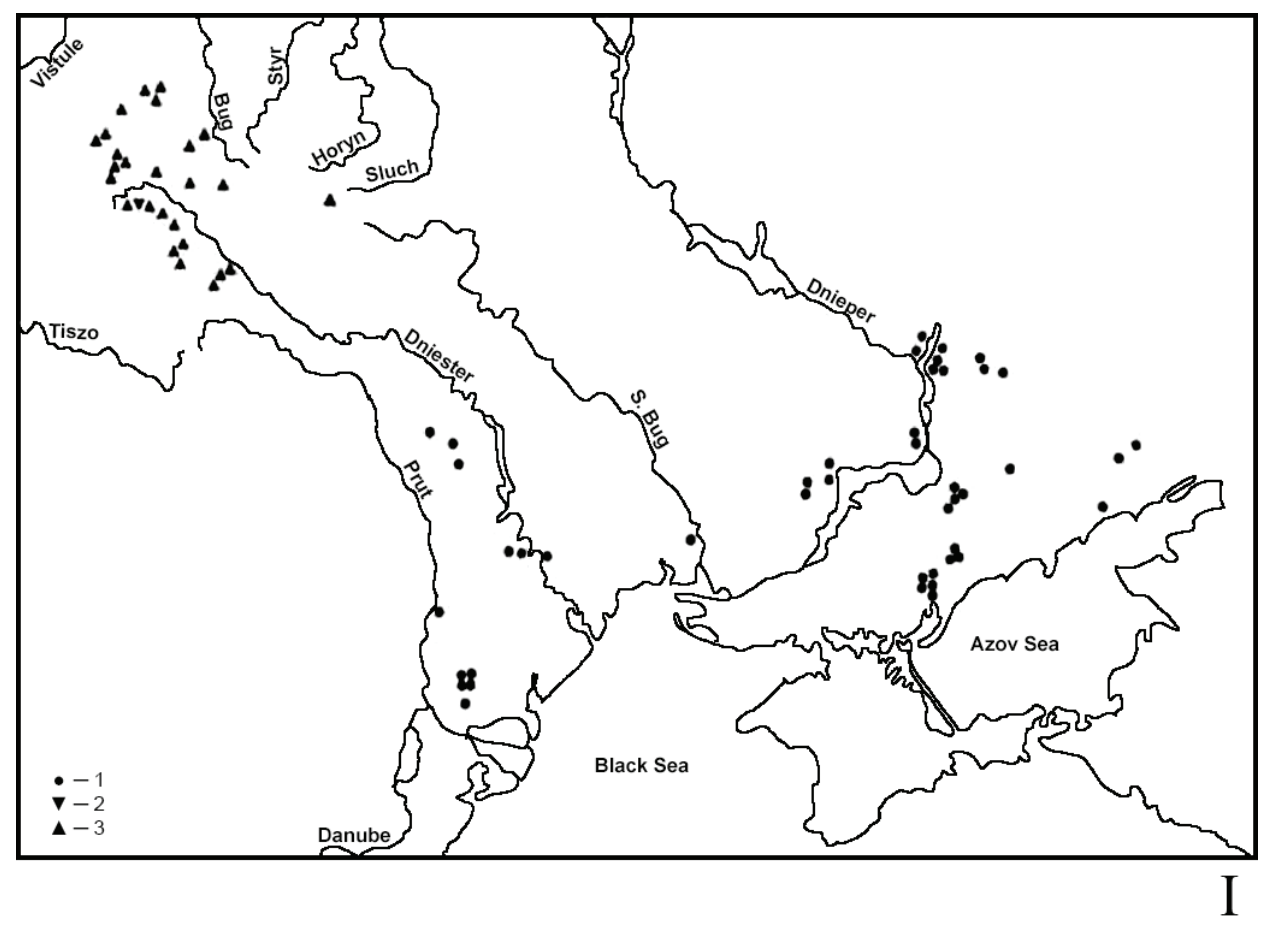

Fig. 1 a . North-western and northern Black Sea Coast in the Late Eneolithic and Early Bronze Age I. Territorial connections between the Zhyvotilovka-Volchansk group - 1, and the CWC - 2, 3 [after Kośko 2000: 342, Fig. 1]

only in the south, mostly on the Budzhak Steppe. These are the complexes of the Usatovo culture, burials of the Černavoda culture (Khadzider cultural group) and the 'Katarzhyno type' sites (post-Sredny Stog) (Fig. 1). Others are known only from the northern portion of the north-western Black Sea Coast (forest-steppe in the interfluve between the Dniester and Prut rivers). These are sites belonging to the late stage of the Tripolye culture (stage C II): the Gordineşti group in the Prut drainage basin and the Chirileni group in the Prut-Dniester interfluve (Fig. 2). Finally, some Late Eneolithic sites were discovered throughout the north-western Black Sea Coast: in both its northern and southern parts. These are burials of the 'Zhyvotilovka type' (Zhyvotilovka-Volchansk) and ones known as 'extended burials' (Figs. 1-3). Moreover, a quite significant number of burials found in the north-western Black Sea Coast are dated by researchers simply to the 'Late Eneolithic'; determining their cultural affiliation within this age is rather troublesome.

Vykhvatintsy-type sites, represented by settlements and flat (ground) cemeteries, are known from the middle Dniester drainage basin, specifically from the 


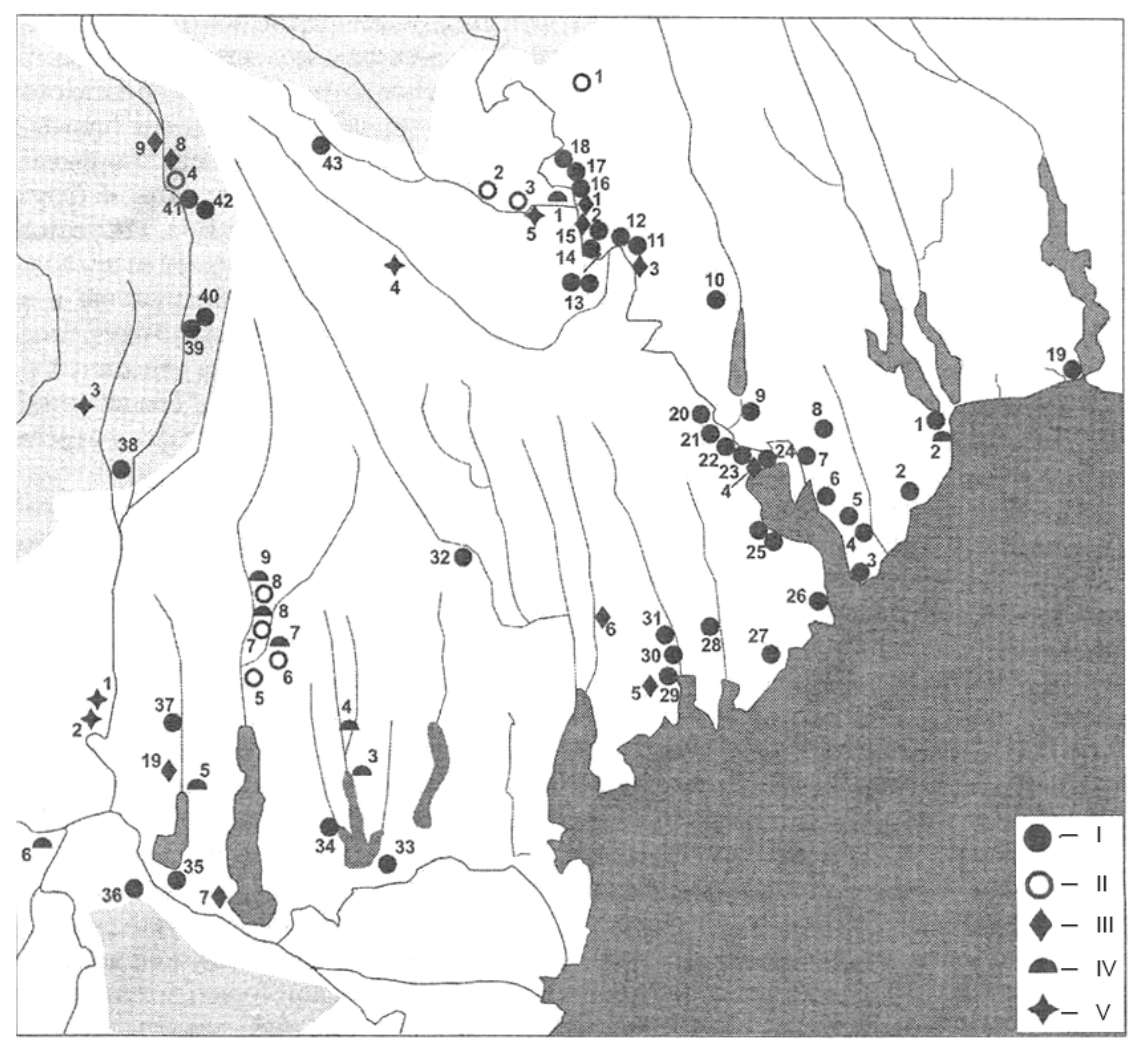

Fig. 1 b. North-western and northern Black Sea Coast in the Late Eneolithic and Early Bronze Age II. Usatovo culture and major synchronous sites of selected types

I Usatovo culture 1 - eponymous site, Usatovo complex - Bolshoi Kuyalnik (stronghold and cemeteries); 2 - Aleksandrovskiy barrow; 3 - Karolino-Bugaz; 4 - Dalnik II; 5 - Nikolaevka; 6 Efimovka; 7 - Mayaki site complex (stronghold, cemetery); 8 - Mayaki-Mirnoe; 9 - Gradanitsy settlement-stronghold (?); 10 - Nikolskoe; 11-12 - Tiraspol; 13-15 - Tîrnauca; 16 - Ploskovskiy; 17 - Crasnogorca; 18 - Speia; 19 - Koshary II-Zmeinaya Balka; 20 - Răscăieţii; 21 - Purcari; 22 - Olăneşti; 23 - Tudora; 24 - Palanka site complex (?); 25 - Sadovoe-Mologa; 26 - Popova Mogila; 27 - Shabolat; 28 - Alkaliya; 29 - Zholtyi Yar; 30 - Zakharkin; Mogila; 31 - Diviziya; 32 - Berezino; 33 - Kislitsa; 34 - Utkonosovka; 35 - Orlovka; 36 - Isaccea; 37 - Gavanoasa; 38 - Riseşti; 39 - Tochile-Răducani; 40 - Sărata-Răzeşi; 41-42 - Dancu 1-2; 43 - Dănceni

II Khadzhider type: 1 - Crasnoe; 2 - Mereni II; 3 - Roșcani; 4 - Sărăţeni; 5 - Kubey; 6 - Kurchy; 7 - Taraclia II; 8 - Cazaclia

III Post-Mariupol culture (extended burials): 1-2 - Parcani; 3 - Sucleia; 4 - Tudora; 5 Vishnevoe; 6 - Sărata; 7 - Chaush barrow (Novoselskoe); 8 - Sărăţeni; 9 - Vishan; 10 - Etulia

IV Zhyvotilovka-type sites: 1 - Gura Bukului; 2 - Slobodka Romanovka; 3 - Suvorovo I; 4 - Kale; 5 - Bolgrad; 6 - Brăiliţa; 7-8 - Taraclia; 9 - Cazaclia

V Floreşti type: 1 - Folteşti; 2 - Stoicani; 3 - Grumezoaia; 4 - Ruseștii Noi; 5 - Calfa [after Petrenko 2013: 169, Fig. 28] 


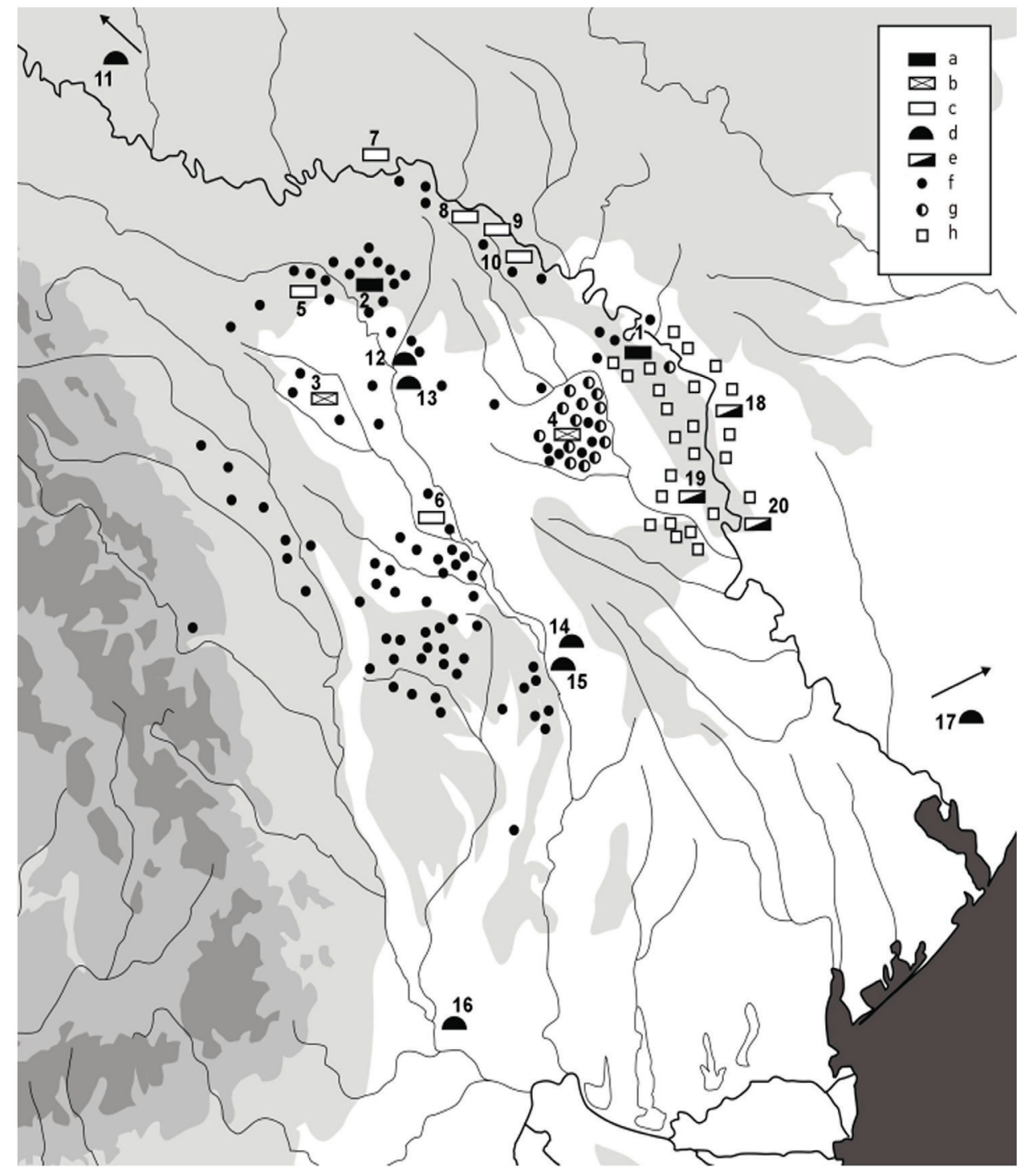

Fig. 2. Late Tripolye sites: (a-e) cemeteries and (f-h) settlements in the region $\mathbf{a}$ - Gordineşti age flat cemeteries: (1 - Cunicea; 2 - Gordineşti - promontory); b - single Gordineşti age flat burials (3 - Boroşoaia; 4 - Tăucra Nouă); c - Gordineşti age intra muros burials (5 Horodiştea; 6 - Cirniceni pe Coaste; 7 - Tsviklovtsy; 8 - Mereshovka; 9 - Tătărăuca Nouă XV; 10 - Pokrovka V); d - Gordineşti age burials beneath barrows (11 - Zavishnia; 12 - Dumeni 16, 17 , 18/3; 13 - Costeşti 4/1; 14 - Obileni 4/8; 15 - Sărăţeni 2/11; 16 - Lieşti 78/22; 17 - Vishnevatoe); e - Vykhvatintsy age cemeteries (18 - Vykhvatintsy; 19 - Oxentea; 20 - Holercani I); f - GordineştiHorodiştea sites; $\mathbf{g}$ - Vykhvatintsy type sites; $\mathbf{h}$ - Chirileni type sites [after Topal, Tserna 2010: 294, Fig. 6] 


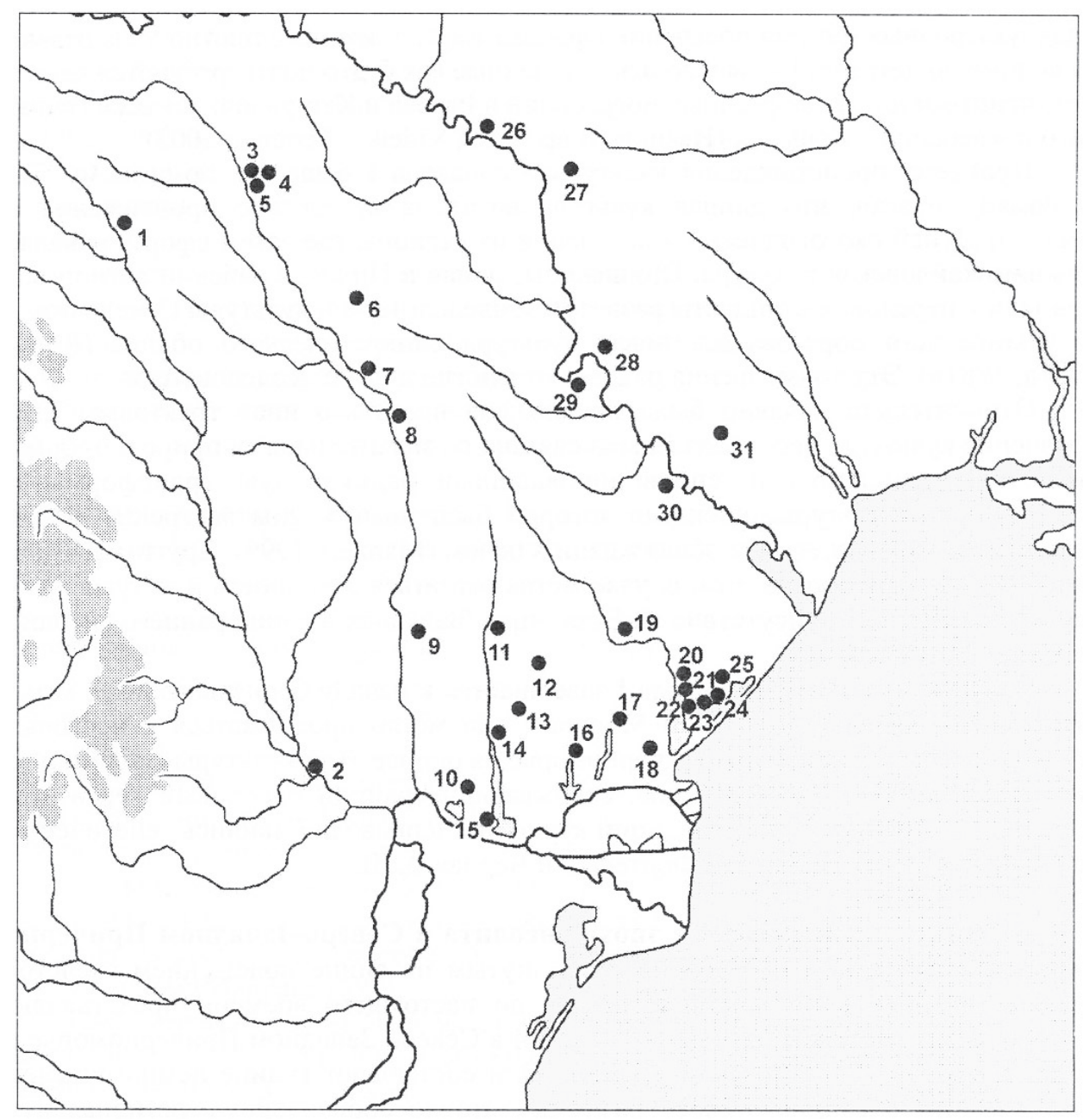

Fig. 3. Map of Eneolithic and Bronze Age prologue extended burials in the Carpathian-Dniester Region. 1 - Corlăteni; 2 - Lungoci-Fundeni; 3 - Dumeni; 4 - Văratic; 5 - Duruitoarea Nouă; 6 Bursuceni; 7 - Petreşti; 8 - Sărăţeni; 9 - Crihana Veche; 10 - Etulia; 11 - Cazaclia; 12 - Ogorodnoe III; 13 - Kubey; 14 - Bolgrad; 15 - Novoselskoe; 16 - Suvorovo; 17 - Kholmskoe; 18 - Desantnoe;19 - Artsyz; 20 - Belolesie; 21 - Novoselitsa; 22 - Trapovka; 23 - Vishnevoe 24 - Kochkovatoe; 25 - Zheltyi Yar; 26 - Ocniţa; 27 - Timkovo; 28 - Crasnoe; 29 - Bălăbănești; 30 - Talmaz; 31 Nikolskoe [after: Manzura 2013: 140, fig. 23]

confluence with the Reut River in the south to the town of Soroca in the north. We know of about 50 Vykhvatintsy-type sites. On the settlements of this type, traditional 'Tripolye' ploshchadki and pithouses are found while flat cemeteries feature inhumations in oval and rectangular pits. The dead usually lie crouched on 

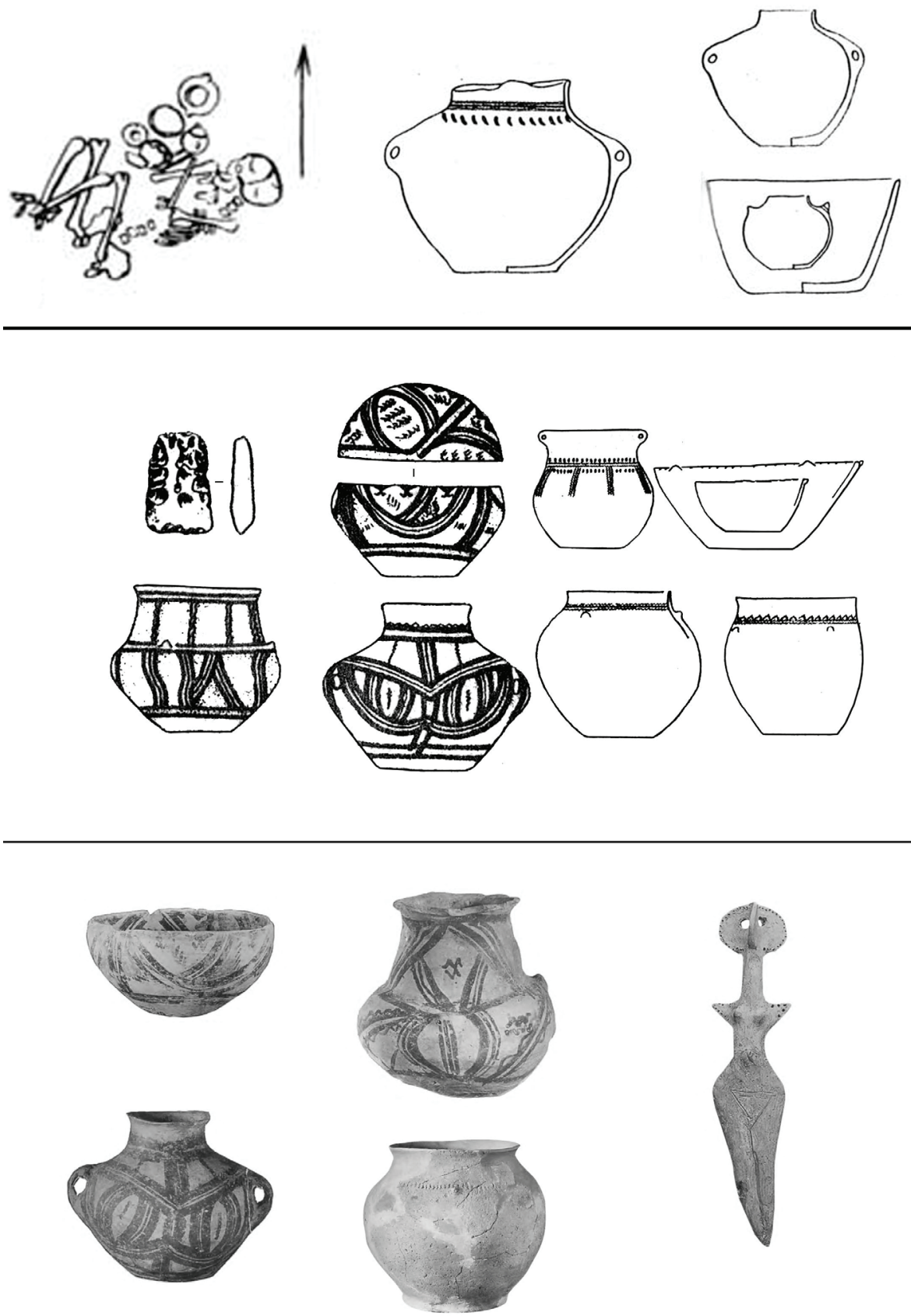

Fig. 4. Vykhvatintsy cultural type

1 - Vykhvatintsy cemetery, burial 5; 2 - materials characteristic of Vykhvatintsy type settlements; 3 - Vykhvatintsy type painted ware and an anthropomorphic statuette [after: 1, 2 - Dergachev 1986: 195, Fig. 28; 2 - Dergachev, Manzura 1991: 224, Fig. 4; 3 - Petrenko 2004: 90-91] 


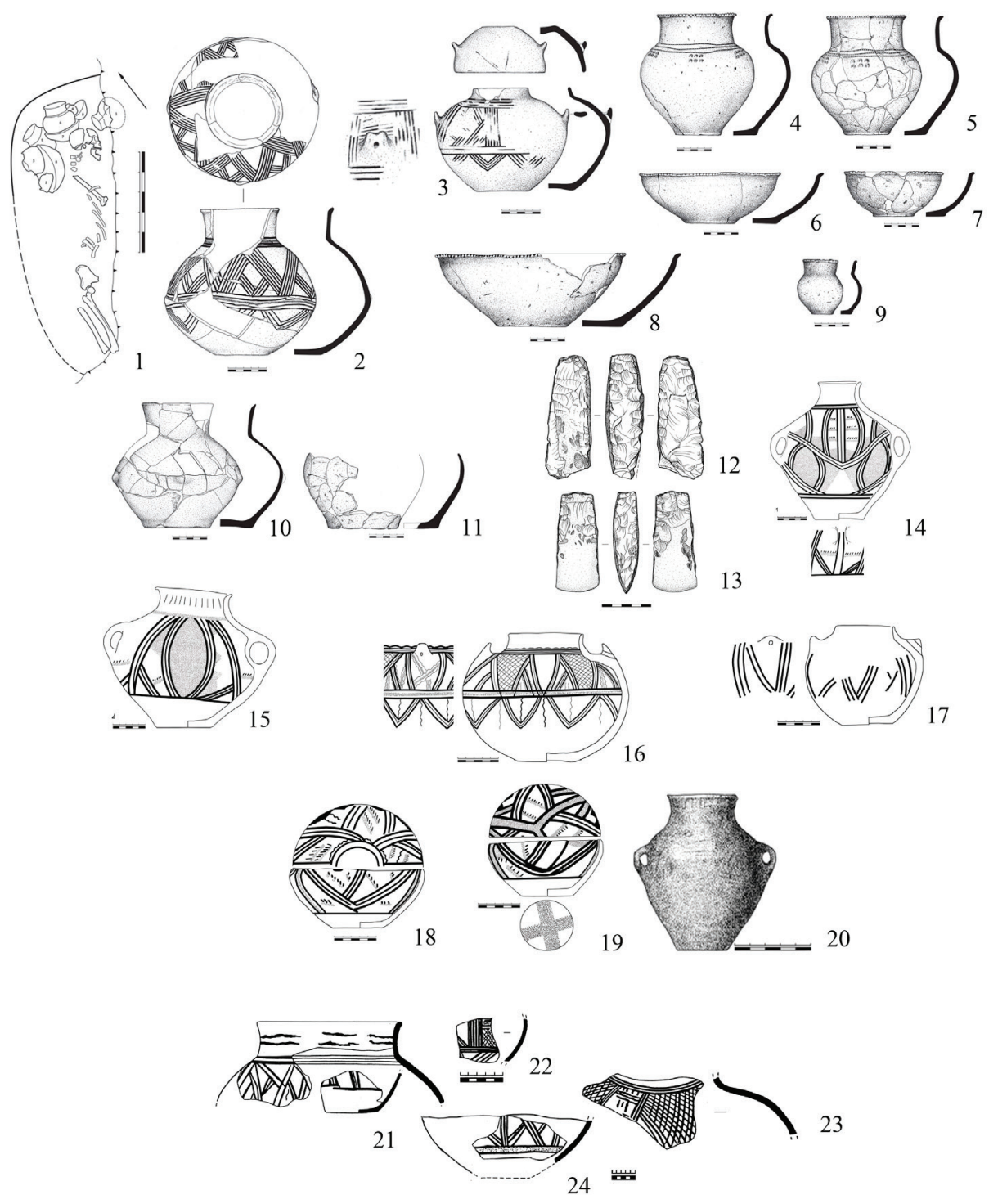

Fig. 5. Chirileni cultural type

1-9 - Cunicea, burial 1; 10-11 - Cunicea, burial 2; 12-13 - Cunicea, settlement; 14-20 - Oxentea cemetery; 21-24 - materials characteristic of Chirileni type sites [after: 1-13 - Topal, Tserna 2010; 14-20 - Yarovoy et al. 2012; 21-24 - Bikbaev 1994: 67, Fig. 2] 
their left side although crouched supine burials are also known; they are oriented northeast in most cases. The set of tools and weapons is small, metal is rare, grave inventories feature mostly pottery (Fig. 4). Characteristic ornaments, made using dark brown and red paints are usually arranged horizontally. Anthropomorphic designs are considered a separate (realistic) Vykhvatintsy type [Dergachev, Manzura 1991: 10].

Chirileni-type sites are believed to be transitional (from the perspective of chronology) between the Vykhvatintsy and Gordineşti types, hence researchers also refer to them by the terms 'post-Vykhvatintsy' and 'pre-Gordineşti' ${ }^{4}$. The pottery shows similarities to Usatovo and Vykhvatintsy materials, on the one part, and to Gordineşti materials on the other (Fig. 5). The similarities concern both pottery forms and painting. The origins of Chirileni-type sites can be linked to the impact of genetically different traditions, which were present in the Vykhvatintsy and Brînzeni types and of the Usatovo, Černavoda I and Folteşti cultures [Bikbaev 1994: 68-69]. Recent years have witnessed the publication of materials from two cemeteries [Chirileni: Cunicea; Topal, Tserna 2010 and Oxentea; Yarovoy et al. 2012]. Both cemeteries are flat and are situated in the middle Dniester drainage basin; the former has been partly investigated while from the latter available materials have been collected in various years. Only fragmentarily does the pottery reflect the combination of Vykhvatintsy and Gordineşti traits. Close to the Cunicea cemetery, there are several Late Tripolye settlement sites [Topal, Tserna 2010: 289292].

Gordineşti-type sites were distinguished almost at the same time under various names such as 'northern' [Movsha 1971] and 'Kasperovtsy' [Zakharuk 1971] groups of the late stage of the Tripolye culture. Only later did V.A. Dergachev propose the name 'Gordineşti', because in his opinion it was the excavated Gordineşti site that could serve as the paragon of traits characteristic of this type of sites [Dergachev 1980: 117]. In Romania, sites of this type are combined into the Horodiştea group, although some Romanian researchers distinguish a group or even a culture named Horodiştea-Erbiceni-Gordineşti-Kasperovtsy [Alaiba 2004: 78; 2007: 130]. The Horodiştea site has yielded the following radiocarbon dates:

Horodiştea I Hd 14785: 4495 ×18 BP; 3331-3101 (1 sigma), 3340-3046 BC (2 sigma)

Horodiştea II Hd 15024: $4377 \pm 21$ BP; 3035-2924 (1 sigma), 3091-2920 BC (2 sigma)

Horodiştea II Hd 14898: $4235 \pm 30$ BP; 2908-2783 (1 sigma), 2916-2703 BC (2 sigma) [Mantu 1998:252]

V.A. Dergachev thought that Gordineşti-type sites were located in the middle and upper Prut and Dniester drainage basins, and on the upper Southern Bug River

\footnotetext{
4 Interestingly enough, most of Chirileni-type sites also in terms of geography are transitionally located for they are found in the central part of the Dniester-Prut interfluve, with Gordineşti-type sites gravitating towards the Prut, while those of the Vykhvatinsty type towards the Dniester (Fig. 2).
} 

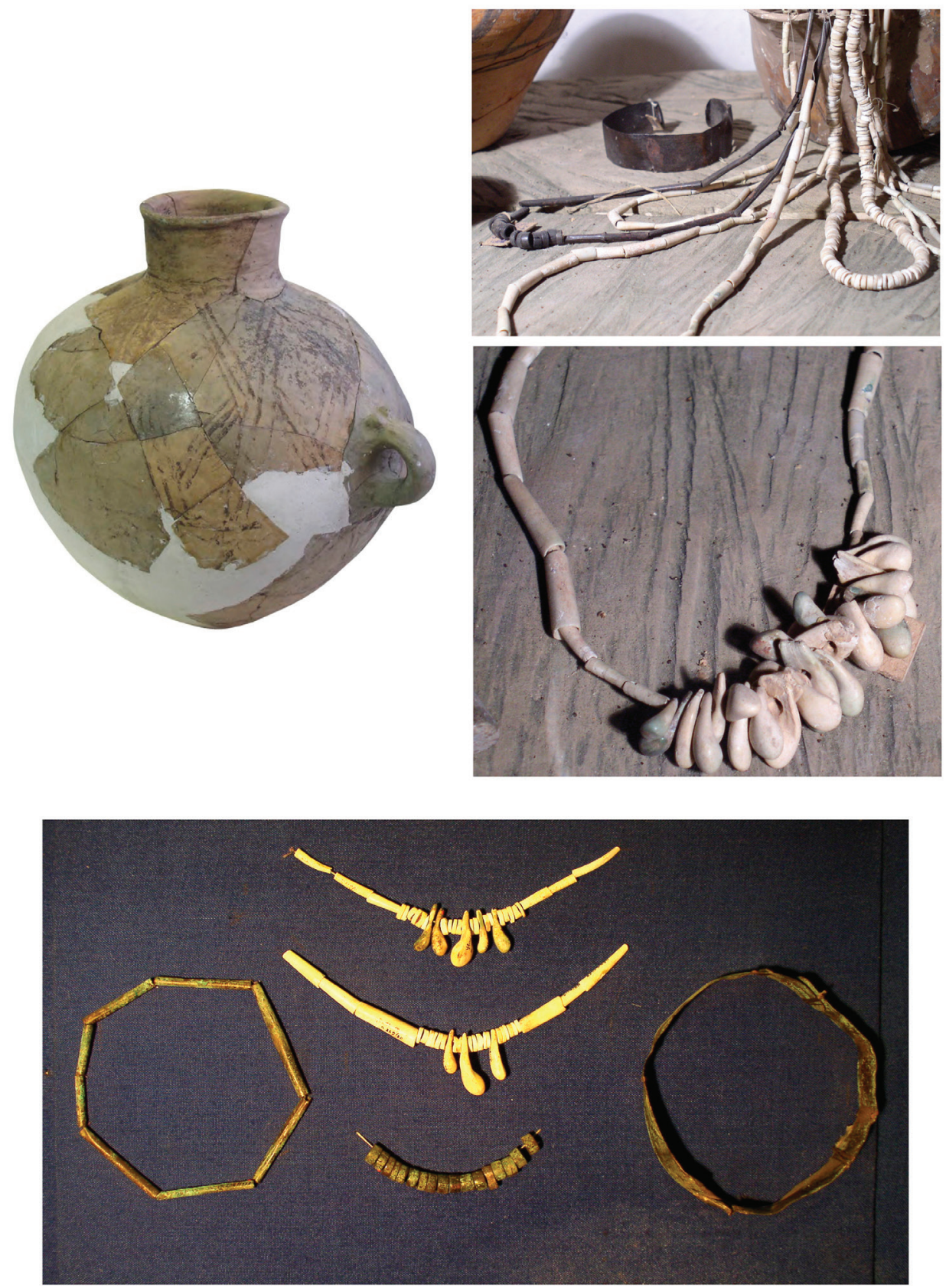

Fig. 6. Tsviklovtsy treasure [after Burdo 2004: 588] 

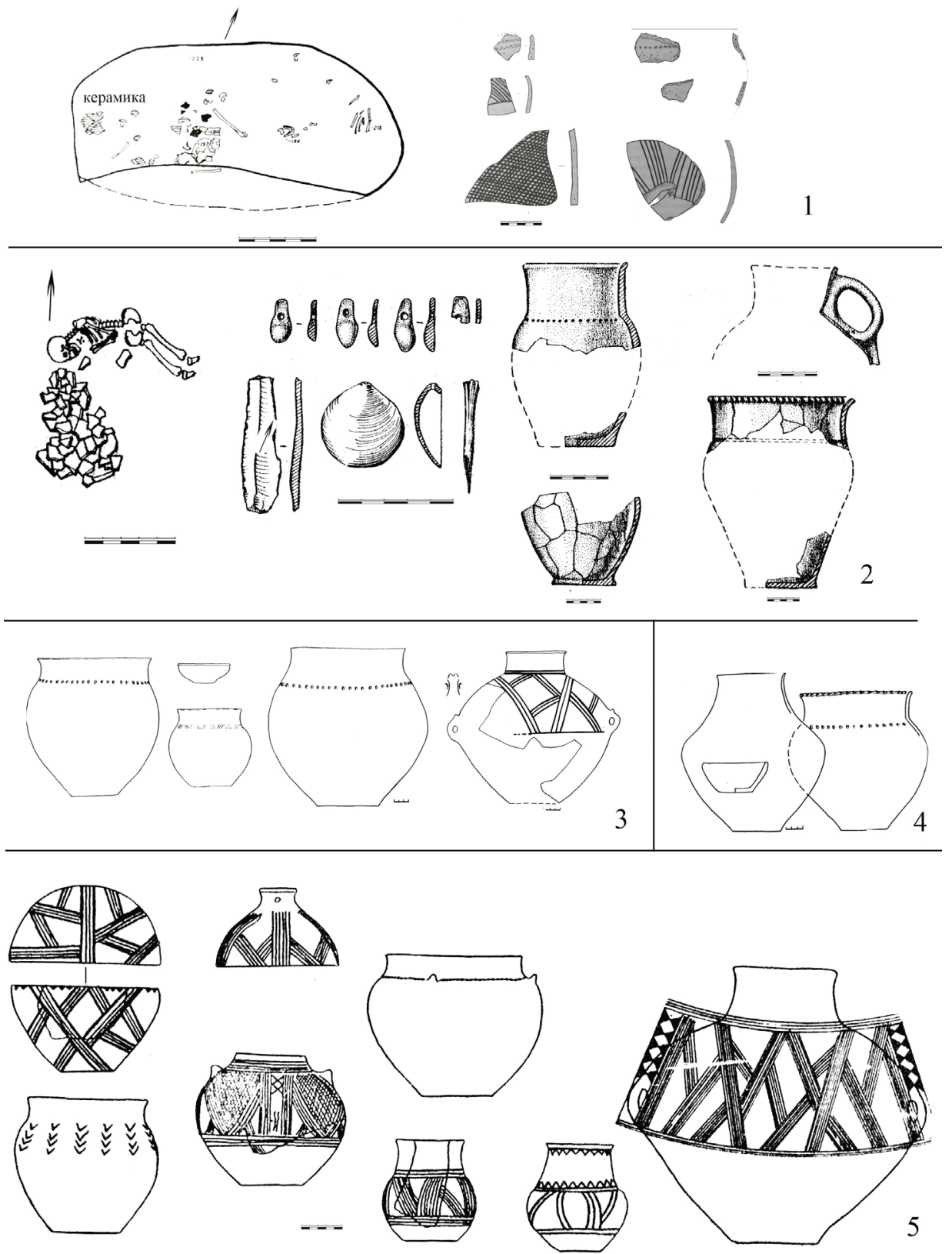

Fig. 7. Gordineşti cultural type

1 - flat burial, Tătărăuca Nouă XV; 2 - burial, Gordineşti-promontory; 3 - vessels from ritual burial (offering), Tsviklovtsy; 4 - vessels from burial on Mereshovka settlement; 5 - materials characteristic of Gordineşti type settlements [after: 1 - Larina 1989: 59, 61 Fig. 2, 3; 2 - Manzura, Telnov 1992: 122, Fig. 1; 3 - Dergachev, Manzura 1991: 309, Fig. 88; 4 - Dergachev, Manzura 1991: 310, Fig. 89; 5 - Dergachev 1980: 198, Fig. 31] 
[Dergachev 1980:119]. Worth mentioning in this context, the opinion of S.N. Ryzhov, who has analyzed pottery from the settlements of the late stage of the Tripolye culture in the Southern Bug-Dniester interfluve, holds that the Gordineşti group should be restricted to sites with Gordineşti-Horodiştea-Erbiceni-type pottery to be found in the drainage basins of the Moldova, Siret, Prut and partially Dniester rivers and that sites situated in the upper and partially middle Dniester drainage basin and in western Podolia ought to be excluded from it [Ryzhov 2001-2002: 198].

The sites of the Gordineşti group include settlements, burials and a hoard found on the Tsvilkovtsy site (Fig. 6). The ceramics complex consists of painted serving ceramics and unpainted cooking ceramics (Fig. 7). A characteristic trait of painted ornaments is their geometric style while relief ornaments on the unpainted ceramics take the form of single and double appliqué bosses on the upper portion of the belly, as well as pinched ornaments and nail impressions along the bottom edge. As typical of this group are considered lids with a mushroom top and bowls with a profiled lip.

V.A. Dergachev believed that the Gordineşti group was genetically linked to the Brînzeni group [1980: 85, 89]. The discovery of Chirileni sites justified a belief that it was they that could be considered the genetic base of the Gordineşti cultural group [Bikbaev 1994: 68-69]. However, the development stages of the Late Tripolye groups of Vykhvatintsy, Chirileni and Gordineşti, and any transitional forms or contacts between them, have not been sufficiently studied [Yarovoy et al. 2012: 298].

Researchers identify also the influence of the Baden culture on the rise of the Gordineşti group, as well as the impact of the Funnel Beaker culture (FBC) and GAC traditions [Videiko 2000: 36, 46, 47], visible in the form and ornamentation of pottery and other artefacts. A number of ornamentation elements on Gordineşti pottery have analogies in the Vistula drainage basin in the Złota and Rzucewo cultures [see Pribrezhnoe: Kośko 2014: Fig. 7], which may have influenced the frontiers of the Pontic and Baltic drainage basins [Videiko 2000: 46].

Gordineşti-type anthropomorphic representational art includes single statuettes. Ornaments of this type are known from a hoard found on the Tsviklovtsy site (Fig. 6.). Objects making up the hoard, 822 in number, were found in a globular amphora with two handles on the upper portion of the belly. Copper had been used to make 68 objects: bracelets, and long tube-like and cylindrical beads. Other objects included a necklace of 122 red deer teeth, 275 mollusc shell beads and 367 limestone beads. Tools were represented by a metal adze, stone axe-hammers, grindstones, fabricators, flint scrapers, sickles, drill bits, and axes. There were also flint arrow points, bone knobbed shaft-hole axes, perforators, slicks and hoes [Dergachev 1980: 121-122].

In principle, Gordineşti-type sites are represented by settlements in which intra muros burials were recorded, with few flat funerary complexes outside settlements also being known. Generally speaking, however, it can be said that the funerary rite 
of the Gordineşti-group tribes as such has not been identified yet. Burials within settlements are rather an exception than a rule. Skeleton remains were discovered in homesteads on a settlement in Horodiştea (Romania), a burial of a woman aged 18-20 was found within a settlement in Mereseuca, Republic of Moldova [Dergachev, Manzura 1991: 142-143]. A human sacrifice of an 18-20-year-old individual (partially cremated) was recorded on the Tsviklovtsy site, Ukraine [Movsha 1964] and

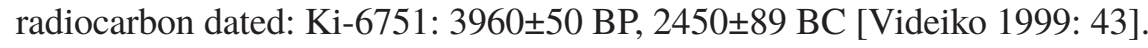

A collective burial of three senile women was discovered on a site in Pocrovca, Dondușeni district, Republic of Moldova ${ }^{5}$. Researchers presume that similar burial complexes have a ritual aspect [Larina 2003: 62]. Single flat extra muros burials are known from Boroşoaia [Chirica, Tanasachi 1985: 306], Cârniceni Pe Coaste [Alaiba, Grădinaru 1999], Romania, Tăura Nouă, Sîngerei district, ${ }^{6}$ Tătărăuca Nouă XV, Dondușeni district, Republic of Moldova [Larina 2003: 57-60, 67].

Out of flat burials, the Gordineşti-promontory site, located near Gordineşti, Edineţ district, stands out where one burial was excavated, but the presence of a cemetery is suspected. It may have formed a complex with the Gordineşti settlement located nearby [Manzura, Telnov 1992: 124]. The corpse lay contracted on its right side, with the head pointing west and hands raised towards the face. The inventory encompassed pottery (fragments of seven vessels), ornaments such as a necklace of split deer teeth and a sea shell as well as tools: a bone perforator and flint blades (Fig. 7:2).

The Tătărăuca Nouă XV site is interpreted as a seasonal settlement designated for economic-production purposes as no homesteads were found within its perimeter. The site is linked by researchers to the Tătărăuca Nouă V settlement located 1.5-2.0 km away and counted among the Gordineşti cultural group [Larina 2003: 58]. A burial on this site was exposed in the course of cleaning a cliff. Its pit was semi-oval, with the longer axis extending west-east; the arrangement of the corpse could not be reconstructed (Fig. 7:1). On the pit bottom, in its fill, there were fragments of painted and cooking ceramics. An anthropological examination shows that the buried individual was a woman, aged 45-55 years and belonging to the Mediterranean type [Varzar, Pezhemskiy 2003].

The burial from Tăura Nouă was a chance discovery made in the course of construction work. Its pit was semi-oval, with its longer axis extending west-east, while its walls were charred. The skeleton most likely lay crouched on its side. The inventory encompassed a black-coloured bowl, a flint axe and a battle-axe with a pointed-down butt made of white stone. The closest settlement contemporaneous with the burial is 1.0-1.5 km away [Larina 2003: 62-64].

Very few Gordineşti-group burials have been discovered. Consequently, there is not enough evidence to answer the question about the typical funerary rite of this

5 Author of excavations: M.B. Schukin, unpublished [after Larina 2003]

6 Author of excavations: V.M. Bikbaev, unpublished [after Larina 2003]. 

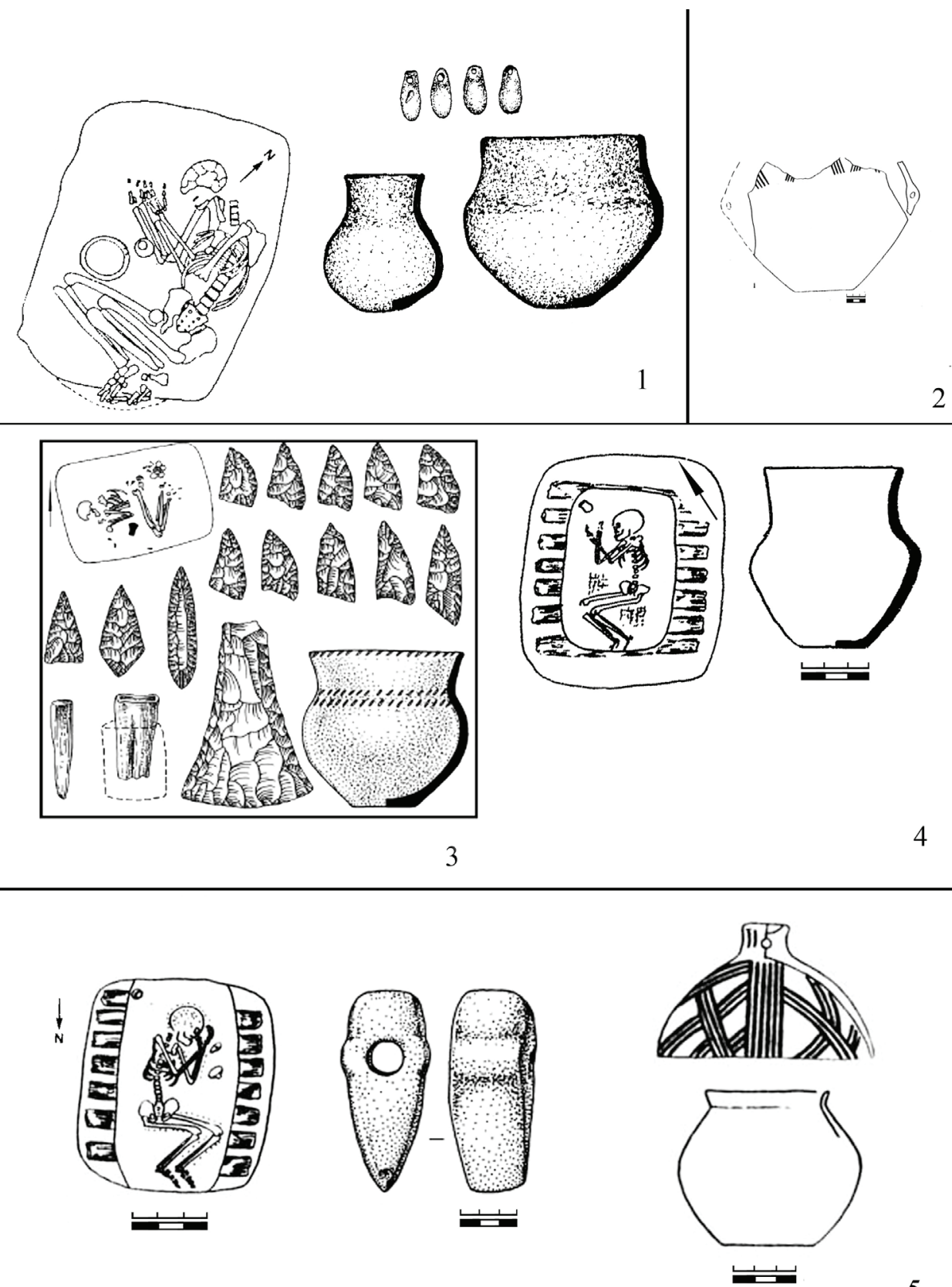

Fig. 8. Zhyvotilovka-Volchansk cultural group

1 - Corlăteni 1/1; 2 - Costeşti 4/1; 3 - Costeşti 2/2; 4 - Taraclia II 10/16; 5 - Taraclia II, 10/17 [after: 1 - Dumitroaia 2000: 284-285, Fig. 76-77; 2 - Dergachev 1982: 15, Fig. 4; 3 - Dergachev 1982: 13, Fig. 3; 4, 5 - Dergachev, Manzura 1991: 256, Fig. 35] 


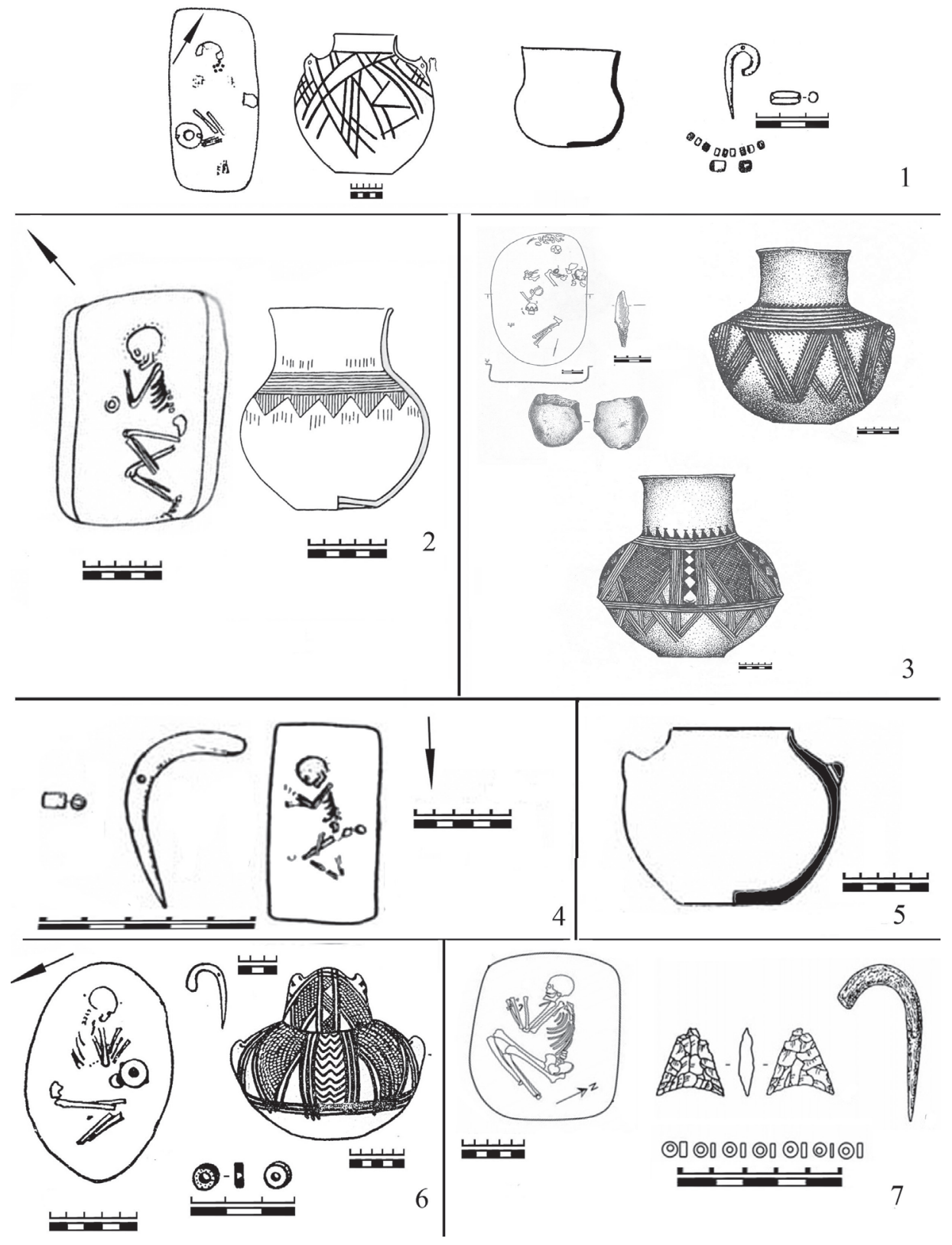

Fi g. 9. Zhyvotilovka-Volchansk cultural group

1 - Taraclia II, 10/2; 2 - Gura Bukului 8/15; 3 - Sărăţeni (Obileni) 4/8; 4 - Tiraspol II, 3/27; 5 - Bursuceni 1/20; 6 - Bolgrad 6/1; 7 - Kale 1/3 [after: 1 - Dergachev, Manzura 1991: 256, Fig. 35; 2 - Dergachev, Manzura 1991: 281, Fig. 264, Fig. 43, 3 - Leviţki et al. 1996: 143-144, Fig. 40, 41; 4 - Dergachev, Manzura 1991: 271, Fig. 50; 5 - Dergachev, Manzura 1991: 260, Fig. 39; 6 - Dergachev, Manzura 1991: 258, Fig. 37; 7 - Russev et al. 2013: 159, Fig. 2] 
community. There is no sufficient evidence as to whether burials with Gordineşti-type ceramics (in the Prut-Dniester area), but lacking the peculiar Caucasian inventories, belong to the Gordineşti or Zhyvotilovka group. ${ }^{7}$ In this context some important questions arise. Did the Gordineşti community adopt the barrow rite or did it use only cemeteries and flat burials? Do Zhyvotilovka-type burials form a separate cultural group or are they merely a type within the Gordineşti cultural group? Should barrows, where burials follow a similar funerary rite but lack any grave goods, be assigned to one of the two groups in question or should a separate group be distinguished? Perhaps, in consequence, we should revisit the idea proposed by I.V. Manzura [Manzura, Telnov 1992: 127] and distinguish a Gordineşti cultural-chronological horizon which would encompass all the sites that show one way or another any connections to the Gordineşti group of the Late Tripolye culture.

It will be possible no doubt to answer these questions as soon as a sufficiently comprehensive database is accumulated.

Zhyvotilovka-Volchansk cultural group. We also know of burials with Gordineşti pottery located in barrows. They were joined together to form a 'Zhyvotilovka cultural group'. ${ }^{8}$ Its characteristic trait can be seen in a peculiar funerary rite - a strongly contracted position on the right side (although cases of placing the corpse on the left side are also known), with the hands placed in front of the face or the chest (Figs. 8,9). The pit is usually rectangular or oval, sometimes with a rather narrow step running around it. The western and southern orientations dominate. It is believed that the traits of this group show both pre-Caucasian (Maikop) and Late Tripolye influence. The latter is believed to include pottery having a Kasperovtsy/Gordineşti look. To the southern (Maikop) influence, researchers attribute bone (more rarely metal) hook- or crosier-shaped pendants, cylinder-shaped beads, slick-surface pottery and southern orientation. I.F. Kovaleva, who distinguished Zhyvotilovka-type sites, explains their emergence with the movement of 'Late Tripolye' (Gordineşti) communities southeast as far as the lower course of the Samara River, on the left bank of the Dnieper [1978, 1991]. The north-western movement is evidenced by a burial in a barrow on the Zavishnia site, Lviv oblast [Dergachev, Manzura 1991: 143].

Furthermore, it is observed that 'Caucasian imports' (slick-surface beakers, bone and metal hooked pendants) moved in the opposite direction as well. Researchers record a concentration of such syncretic sites close to the south-eastern frontier of the Tripolye culture and in the north-western periphery of Maikop culture communities. In the central portion of the territory in question, such finds are rarer [Gey 2011: 14].

7 We know of burials with a similar funerary rite but lacking any grave goods; should they be assigned to one of the two groups in question or should a separate group be distinguished?

8 Only later did Y.Y. Rassamakin call it Zhyvotilovka-Volchansk. 
Not all the sites classified as the Zhyvotilovka-Volchansk type demonstrate the co-occurrence of all the 'obligatory' components of the funerary rite and inventory. For example, there are burials with pottery but without any bone pendants (Figs. 8; 9:2, 3), and vice versa (Fig. 9: 4, 7).

On the eastern bank of the Dnieper, on the middle course of the Samara, a locally-made amphora was found (Boguslav 23/12), which displays analogies to the GAC [Kovaleva 1991; Szmyt 1999: 151]. In the west of the area in question, amphorae characteristic of the entire Late Tripolye horizon stand out (Fig. 9:5). In Gordineşti-type settlements and Zhyvotilovka-group burials, there are encountered beakers with a tall cylindrical neck and globular belly, sometimes bearing an ornament of thin lines incised (or impressed with a thin cord) to form a band of triangles. The beakers are made of cohesive clay whose slick surface ranges from orange to black in colour (Fig. 9:2). We also know of beakers with flanged lips (Fig. 8:4). Some researchers link their origins to the FBC. They also record the impact of Carpathian and Central European cultures on shaping the ceramic complex of the Zhyvotilovka cultural group [Rassamakin 1997: 293].

Researchers believe that the Zhyvotilovka community played a special role in establishing contacts ('bridge') between rather distant areas; the North Caucasus, on the one part, and the Southern Bug and Dniester rivers, on the other part. Y.Y. Rassamakin [2002: 50] sees in this process a more active role of Caucasian tribes, although he admits that the first impulse originated from Gordineşti. A.N. Gey in turn, discussing Zhyvotilovka-type assemblages, believes that the role of migrations should not be overestimated in this case. Finds of objects may be a sign of long-standing interactions and relations of various kinds. Moreover, migrations could have consisted of the series of small shifts or 'shuttle' movements. Such movements and contacts could have had various purposes: exchange, trade, spoils of war, borrowing of technological devices, etc. [Gey 2011: 16-17].

The cultural attribution of these sites presents a problem, though. Researchers tend to assign one and the same burials, located in barrows, to the Zhyvotilovka type and the Late Tripolye Gordineşti group. The criteria of distinguishing 'Gordineşti-type burials' vary from author to author; they include pit shape, dimensions and orientation [Larina 2003:64], or the presence of Gordineşti pottery or a bone 'pendant-hook', as well as corpse arrangement and orientation [Manzura, Telnov 1992: 121, 127].

A more cautious approach to this problem is taken by D.A. Topal and S.V. Tserna. They distinguish a group of sites using the criterion of 'Gordineşti time', believing that today there are no other clear criteria for distinguishing Gordineşti-type burials [Topal, Tserna 2010: 294].

However, there still remains the question of distinguishing between Zhyvotilovka and Usatovo burials without any grave goods. In the Usatovo culture, about 60 per cent of corpses lie on their left side, about 10 per cent on the right, and about 20 per cent lie supine. In 30 per cent of burials, the skeleton lay in the position of 
adoration, i.e. its hands were close to the face [Patokova et al. 1989: 95-96]. The Zhyvotilovka rite, in turn, is characterized by the placing of the dead on their right side, with the hands arranged close to the face as well, but there are also corpses found lying on the left side. Sometimes, both arrangements are recorded in a single grave. In terms of orientation, the Usatovo funerary rite is known for the preference for north-eastern and north-western directions. It is believed, in contrast, that in the Zhyvotilovka rite, western and southern orientations dominate, but arrangements according to various points of the compass (Figs. 8,9) are recorded as well. As a result, it is not always possible to determine the cultural attribution of burials deprived of any grave goods.

Some burials of the Zhyvotilovka group from the north-western Black Sea Coast have radiocarbon dates, coinciding with period CII of the Tripolye culture:

[Petrenko, Kovaliukh 2003: 108]

Bursuceni 1/20 (Hd-19362: 4548 \pm 28 BP; 3345-3120 (1 sigma), 3360-3100 BC (2 sigma),

Bursuceni 1/21 Hd-19933: 4462 22 BP; 3110-3030 (1 sigma), 3130-3030 BC (2 sigma)

Crasnoe 9/10 Hd-19389: 4467×34 BP; 3295-3040 (1 sigma), 3335-2925, BC (2 sigma),

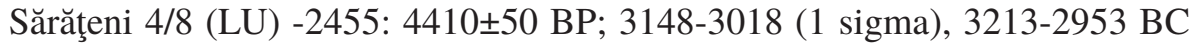
(2 sigma).

They are supplemented by a burial from the Vinogradnyi 2/4 site on the

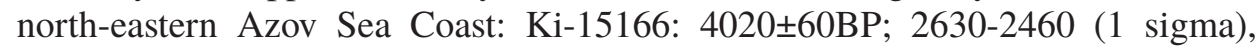
2900-2300 BC [Rassamakin 2009: 290].

At this juncture it is relevant to observe similarly dated burials. In the Bursuceni 1/20 grave [Manzura, Dergachev 1991: 59], a semicircular bowl and an amphora with unpainted handles were found (Fig. 9:5). The Bursuceni 1/21 feature held the burial of one adult and three children. Its grave goods included three vessels, a bone pendant-hook, a gold ring twisted 1.5 times, a flint flake and ten circular shell beads. One of the vessels was shaped like a beaker with a globular belly and a tall, funnel-shaped neck [Yarovoy 2000: 17] ${ }^{9}$.

The Crasnoe 9/10 burial, in which a woman has been deposited, grave goods were included: a red-deer antler digging tool or club, a 'carpenter's kit' (term suggested by G.F. Korobkova), consisting of a stone adze to work wood, flint chisel to work wood, six flint knife insets, flint carving knife, flint adze, three clubs made of animal cut antlers, polished and painted with a red and black paint. The burial was located in a catacomb.

In the Sărăţeni (Obileni) 4/8 burial (Fig. 9:3), the skeleton was badly damaged while the grave goods included a hammerstone, miniature copper knife, amphora and beaker with a tall neck. Both vessels bore a geometric ornament made using

9 The Bursuceni cemetery was excavated by E.V. Yarovoy in 1979. It has not been published yet. 

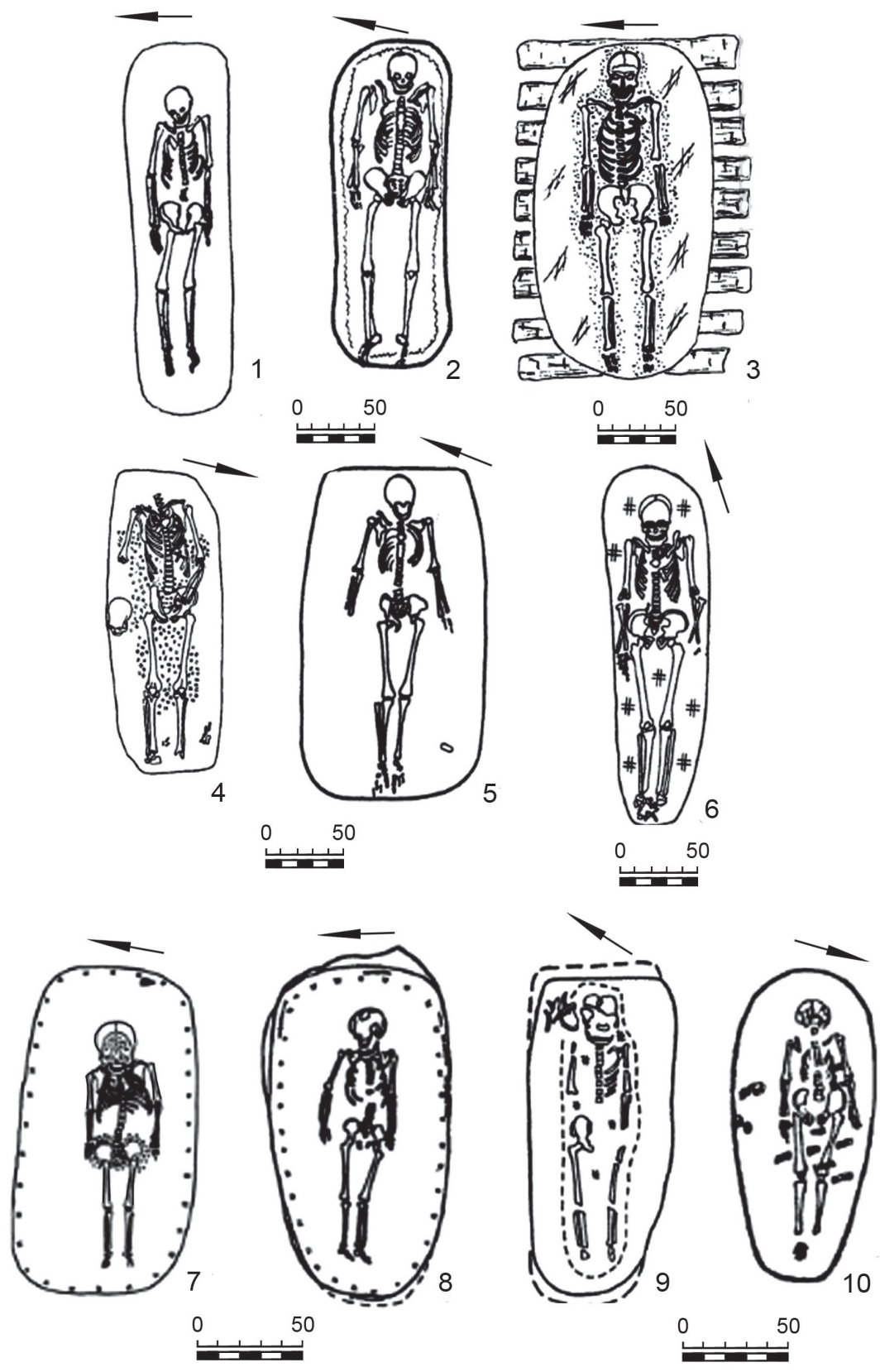

Fig. 10 . Late Eneolithic and Early Bronze Age extended burials on the north-western Black Sea Coast

1 - Ogorodnoe III 1/12; 2 - Timkovo 1/5; 3 - Etulia 1/14; 4 - Ocniţa 1/14; 5 - Vishniovoe 11/10; 6 - Nikolskoe 8/7; 7 - Ocniţa 1/14; 8 - Sărăţeni 2/3; 9 - Cahul 1/15; 10 - Kochkovatoe 30/2 [after Manzura 2010: 37, Fig. 2] 
a technique of monochromatic painting. Relying on morphological and stylistic traits, the pottery from this burial is linked to the Gordineşti culture and analogies are drawn to a beaker from a burial on the Gura Bukului 8/15 site [Leviţi et al. 1996: 82-83].

In the north of the Prut and Danube interfluve, only single barrow burials represent the Zhyvotilovka cultural group. These are: Bursuceni 1/20, 1/21, 1/25, Văratic2/1, Costeşti 2/2, 4/1. They are supplemented by a burial from Corlăteni 1/1, Romania. The inventory from a grave in Costeşti 2/2 (Fig. 8:3) - asymmetrical, triangular arrows - is linked to North Caucasus sites [Dergachev 1982: 11-12, 27], in particular the Maikop culture [Larina 1989: 74].

The latest discoveries of Zhyvotilovka-Volchansk group features have been made by the Yampil Expedition of the Adam Mickiewicz University in Poznań and the Institute of Archaeology, Ukrainian NAS in Kyiv [see Klochko et al. 2015; Goslar et al. 2015; Ivanova et al. 2015].

Group of extended burials (post-Mariupol/Kvitanska group). Sites of this type are spread throughout the north-western Black Sea Coast, both in the steppe and forest-steppe zones (Fig. 3). The group of extended burials is not homogeneous in terms of both chronology and typology (Fig. 10). There are primary and secondary (sunk) burials. Sunk burials always succeed Late Eneolithic crouched or extended burials. Their inventories are rather uncharacteristic (flint goods, pottery tempered with crushed shells and ornamented with combing patterns on the surface). A few extended burials were also observed, judging by stratigraphy, in the mass of YC features in this region. They are the latest in this rather diversified and time-varied group.

It is presumed that extended burials were practised over a long period of time (Eneolithic and Bronze Age) and in different cultures on the north-western Black Sea Coast [Subbotin 1991: 72]. I.F. Kovaleva, however, formed them into a territorial group of the post-Mariupol burials of the north-western Black Sea Coast marked by a later chronological position in comparison with other regions [2002]. Y.Y. Rassmakin linked the extended burials to the Kvitanska culture by observing that in the Dniester-Prut interfluve and on the lower Dniester the set of principal traits was lost [2000: 163-164] and synchronized the extended burials of the Dniester-Danube interfluve with the Usatovo culture [2013: 29]. He dated the Kvitanska culture in the broad chronological framework of the Tripolye culture to phases BII-CI/CII-CII [2013: 38]. I.V. Manzura on the other hand, believes that from the chronological perspective extended burials can be tied to the various periods of the Eneolithic [Rassamakin 2013: 139-153; Leviţki et al. 1996: 59-61]. He traces the tradition of extended burials to the influence exerted by the populations living on the lower Danube or to the local (i.e. of the Prut-Dniester) Mesolithic tradition. The discovery of a Mesolithic cemetery in Sacarovca, northern Moldova, featuring an analogous funerary rite, proves his point [Mazura 2013: 151]. Some late period burials may be attributed to the 
post-Mariupol culture [Manzura 2010: 44]. Furthermore, one may argue Manzura is very right to believe that such burials do not represent a uniform archaeological culture but may be considered as belonging to several typological groups or ones existing at various times.

Besides stratigraphic data, the form of the grave chamber is important. To the variants of its corners (generally examined throughout the Black Sea Coast), researchers turned their attention already some time ago [Nikolova, Rassamakin 1985: 52-53].

I.V. Manzura, having analyzed barrow stratigraphy, concluded that the most archaic group was made up of burials deposited in wide, oval pits. This tradition continued for a long time, practically throughout the Eneolithic and until the Early Bronze Age, i.e. from the second half of the 5th to the end of the 4th millennium BC. The second group of burials, ones placed in narrow, elongated pits, may in his opinion be preliminarily dated to the 4th millennium BC. The latest of burial groups, comprising burials placed in rectangular pits, should be considered as belonging already to the Early Bronze Age, within the $\mathrm{YC}$, which can be dated to the first half of the 3rd millennium BC [Manzura 2013: 150-151].

In the middle Dniester drainage basin, we know of only two extended burials: Ocniţa (Camenca) 6/24 and 7/14 [Manzura et al. 1992: 82-89]. These barrows are located in close proximity to the Yampil Barrow Cemetery Complex [Potupczyk, Razumow 2014].

Extended burials without any gave goods on the north-western Black Sea Coast have yielded a few radiocarbon dates:

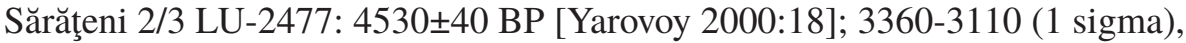
3370-3090 BC (2 sigma) $)^{10}$

Vapniarka 4/4 Ki-15013: 4100 \pm 80 BP; 2870-2560 (1 sigma), 2880-2480 BC (2 sigma) [Ivanova 2009: 53]

Aleksandrovka 1/17 Ki-9526: 4010 \pm 60 BP; 2621-2463 (1 sigma), 2900-2300 BC (2 sigma) [Petrenko, Kovaliukh 2003: 106]

For areas lying further north, there has been no radiocarbon dates until recently. The situation has been changed by the studies on the chronometry of the Yampil Barrow Cemetery Complex. They have made the findings concerning the lifespan of 'Late Eneolithic' communities significantly more accurate [Goslar et al. 2015].

10 Calibrated using the Oxcal Software 


\section{YAMNAYA CULTURE IN THE MIDDLE DNIESTER AREA}

The sites in the interfluve between the middle Dniester and Prut rivers stand out against those located on the north-western Black Sea Coast because of some special traits of their funerary rite and grave goods. However, these differences are not strong enough to justify the distinguishing of a separate YC variety. Such a distinction is justified in the case of the sites of the entire north-western Black Sea Coast, which are interpreted as a local variety [Merpert 1974] or a separate culture [Klein 1975; Cherniakov 1979; Alekseeva 1992] on the strength of a complex of traits. ${ }^{11}$ They include a strong domination of flat-bottomed pottery, western orientation of the dead in principal burials, and the scatter pattern of secondary burials. The pottery is dominated by flat-bottomed pots (Fig. 11:1), with vessels reflecting the impact of other culture standing out: amphorae, beakers (Figs. 11:8-11; 12:1-3) and vessels associated with the Balkan-Carpathian Region (Fig. 12:5-15). There also occurs pottery characteristic above all of the north-western Black Sea Coast, such as amphora-like vessels ('small amphorae') (Fig. 11:5-7) 'Budzhak pots' ('jars') and pot-like vessels (Fig. 11:2-4). Some types are so rare that only single specimens occur (Figs. 11:12; 12:5-15), while others are quite common, for instance, bowls (Fig. 12:4). Among other inventory categories, silver temple pendants and stone and flint shaft-hole axes (Fig. 13:1-11; 14:11, 12, 16, 21 ), concentrated in the region, merit to be mentioned. In other YC regions similar artefact categories do not occur at all or only as single specimens. Barrows containing a large number of graves display a peculiar scatter pattern. Burials are often grouped around the first grave (the major one among pit burials), spreading like an arch (or several arches) or a circle. There occur ditches, cromlechs or stone kerbs around barrow mounds.

The other traits of sites on the north-western Black Sea Coast are common to other YC regions. Grave chambers are usually rectangular with rounded corners. About 30 per cent of pits have a step running around its walls. Grave pits often have a stone or wooden cover, lying along or across the pit. There are examples of anthropomorphic stelae found in covers, cromlechs or barrow mounds. Skeletons most often lie crouched on their back, only less often do they lean to one side or lie crouched on their side. Grave goods include work tools and weapons made of stone, flint, copper/bronze and bone. Copper was used to make ornaments, usually temple pendants, tubes and beads for bracelets. Among other finds, there are bone ornaments: beads, pipe-like beads, small maces, necklaces and pendants made of animal teeth (deer, wolf, dog).

11 The major traits of YC materials from the north-western Black Sea Coast were described in Ivanova 2013: 83-94. 


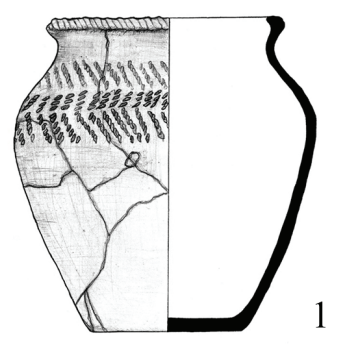

\begin{tabular}{lll}
$0 \quad 2$ \\
\hline
\end{tabular}
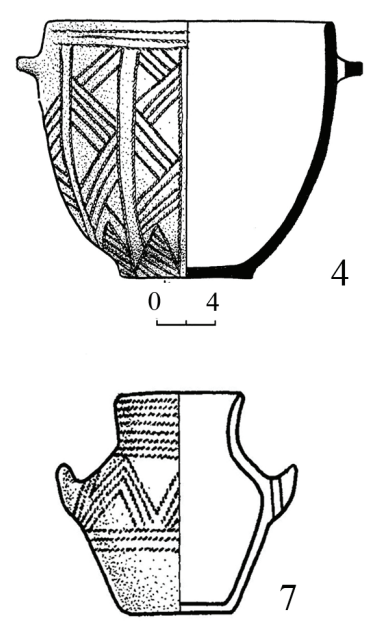

7

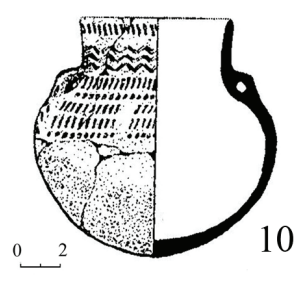

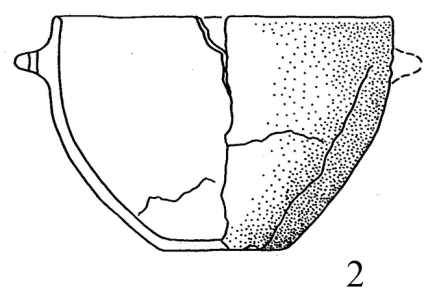

0.2
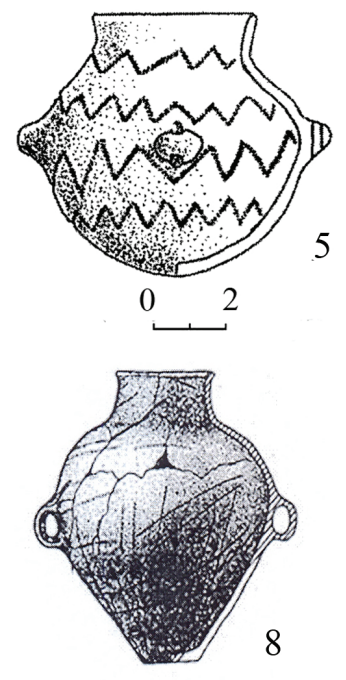

8

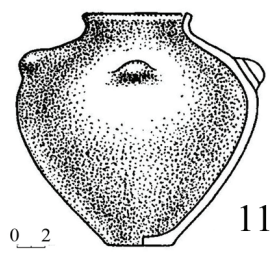

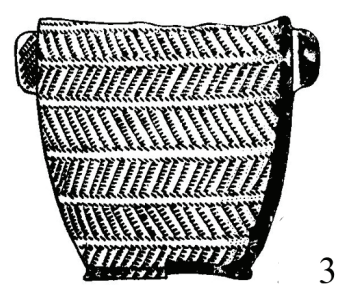

$0 \quad 2$
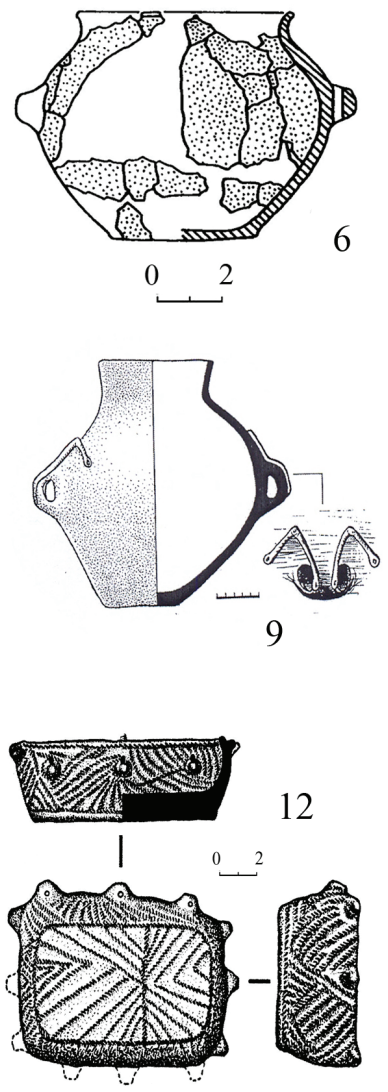

Fig. 11. Yamnaya culture pottery from the north-western Black Sea Coast

1- Sychavka 1/10; 2 - Revova 3/7; 3 - Purcari 1/23; 4 - Diviziya 6/3; 5 - Baranovo 1/9; 6 - Liubasha g. 2; 7 - Mikhailovka 3/6; 8 - Cazaclia 3/13; 9 - Gradeshka 1,5/11; 10 - Mocra 3/4; - Corpaci 2/13; 12 - Grigorăuca 1/8 [after: 1 - Ivanova, Savelev 2011; 2,5,6 - Ivanova et al. 2005; 3 - Yarovoy 1990; 4 - Subbotin et al. 2001-2002; 7 - Subbotin 2000; 8 - Agulnikov 2008; 9 - Subbotin et al. 1995; 10 - Kashuba et al. 2001-2002; 11 - Yarovoy 1984; 12 - Agulnikov, Popovich 2010] 

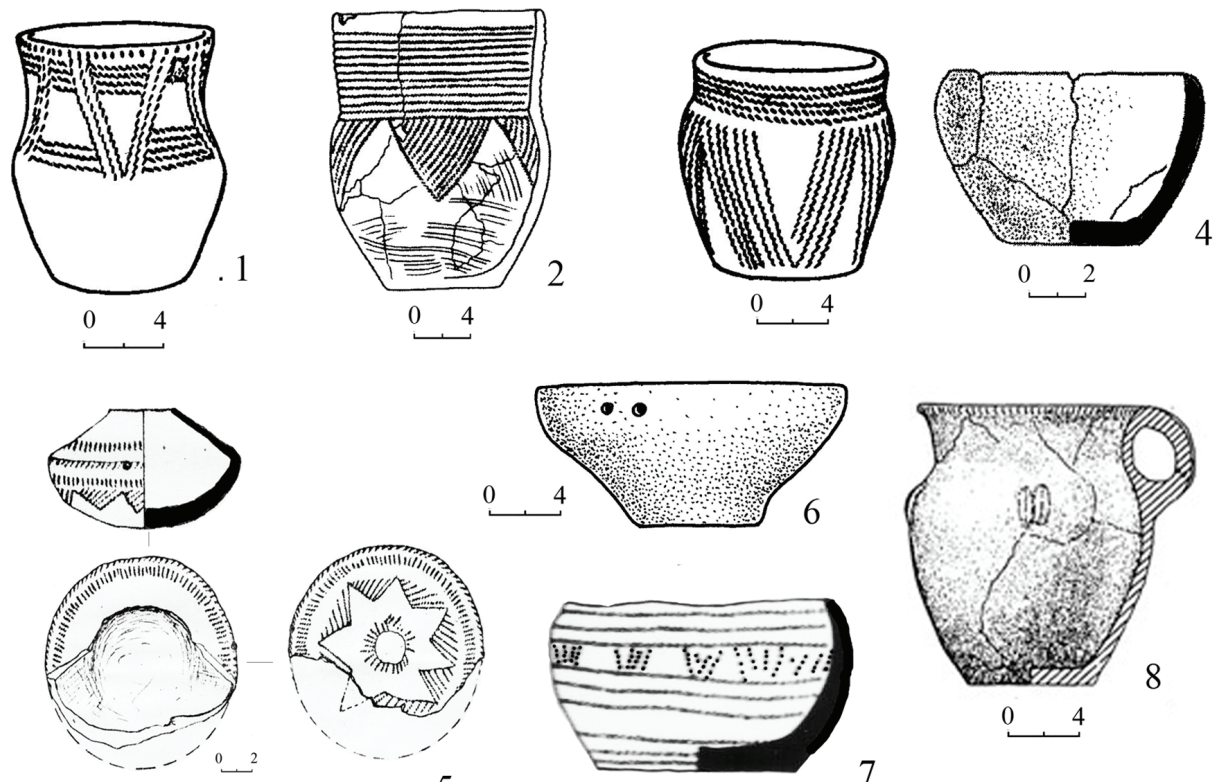

5
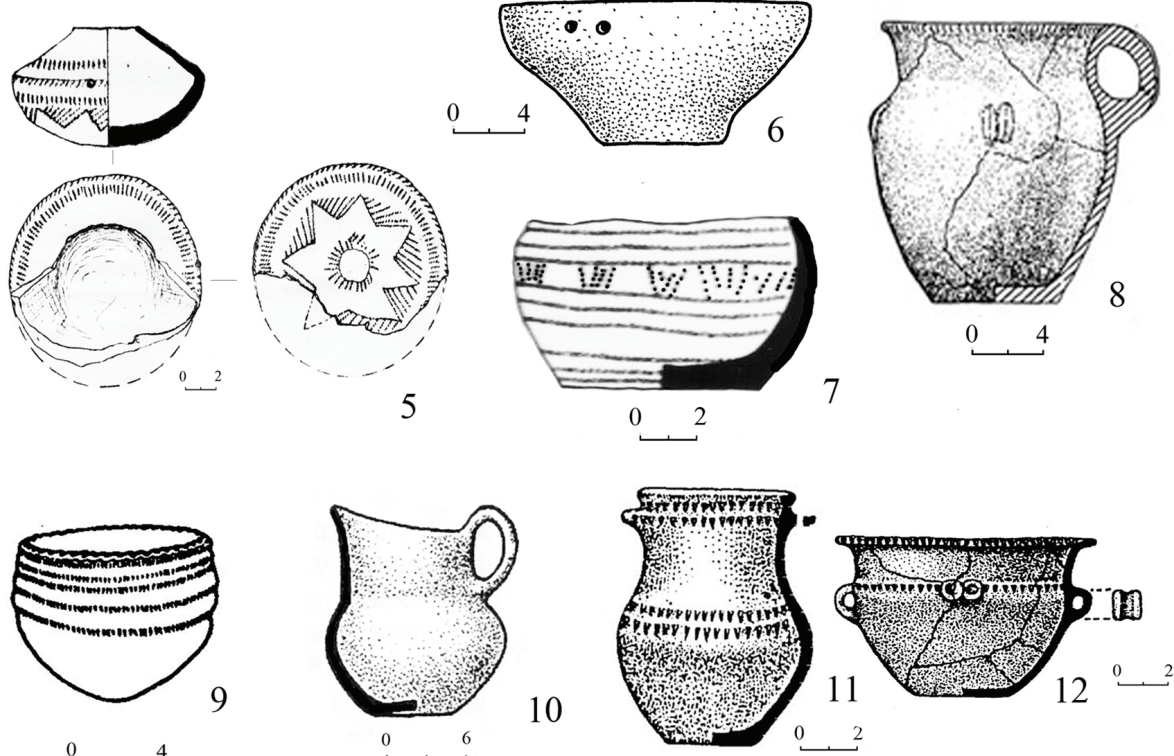

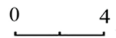
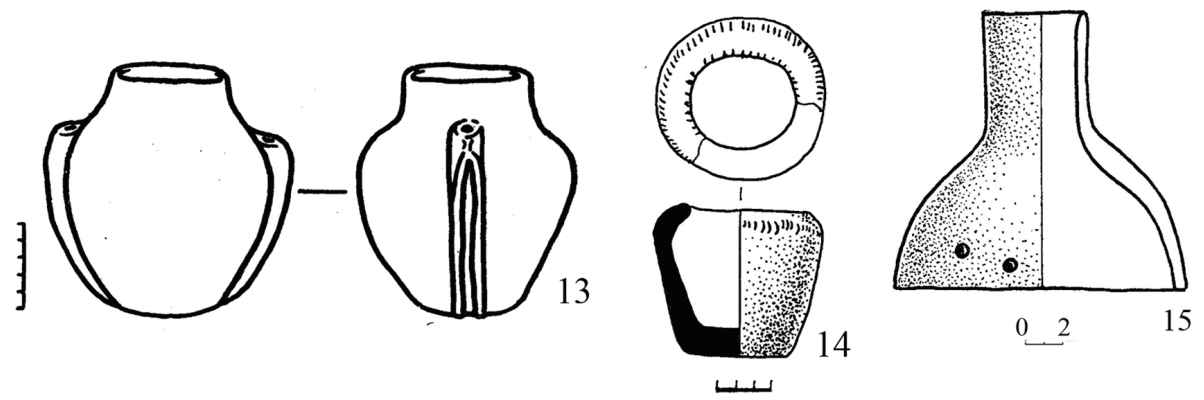

Fig. 12. Yamnaya culture pottery from the north-western Black Sea Coast 1 - Bashtanovka 7/12; 2 - Kholodnaya Balka 1/13; 3 - Bashtanovka 7/21; 4 - Baranovo 1/9; 5 -Vinogradovka (former Kurchy) 3/8; 6 - Primorskoe 1/34; 7 - Novogradkovka 5/14; 8 - Taraclia 16/5; 9 - Nerushay 9/49; 10 - Glubokoe 2/11; 11 - Taraclia 14/16; 12 - Taraclia 14/1; 13 - Bolgrad 5/6; 14 - Vishnevoe 52/3; 15 - Novogradkovka 1/10 [after: 1, 3, 9, 10 - Shmagliy, Cherniakov 1970; 2 - Petrenko 2010; 4 - Ivanova et al. 2005; 5 - Toschev 1992; 6 - Chebotarenko et al. 1993; 7,15 - Subbotin et al. 1986; 8, 11, 12 - Agulnikov 1995; 13 - Subbotin, Shmagliy 1970; 14 - Subbotin et al. 1998] 


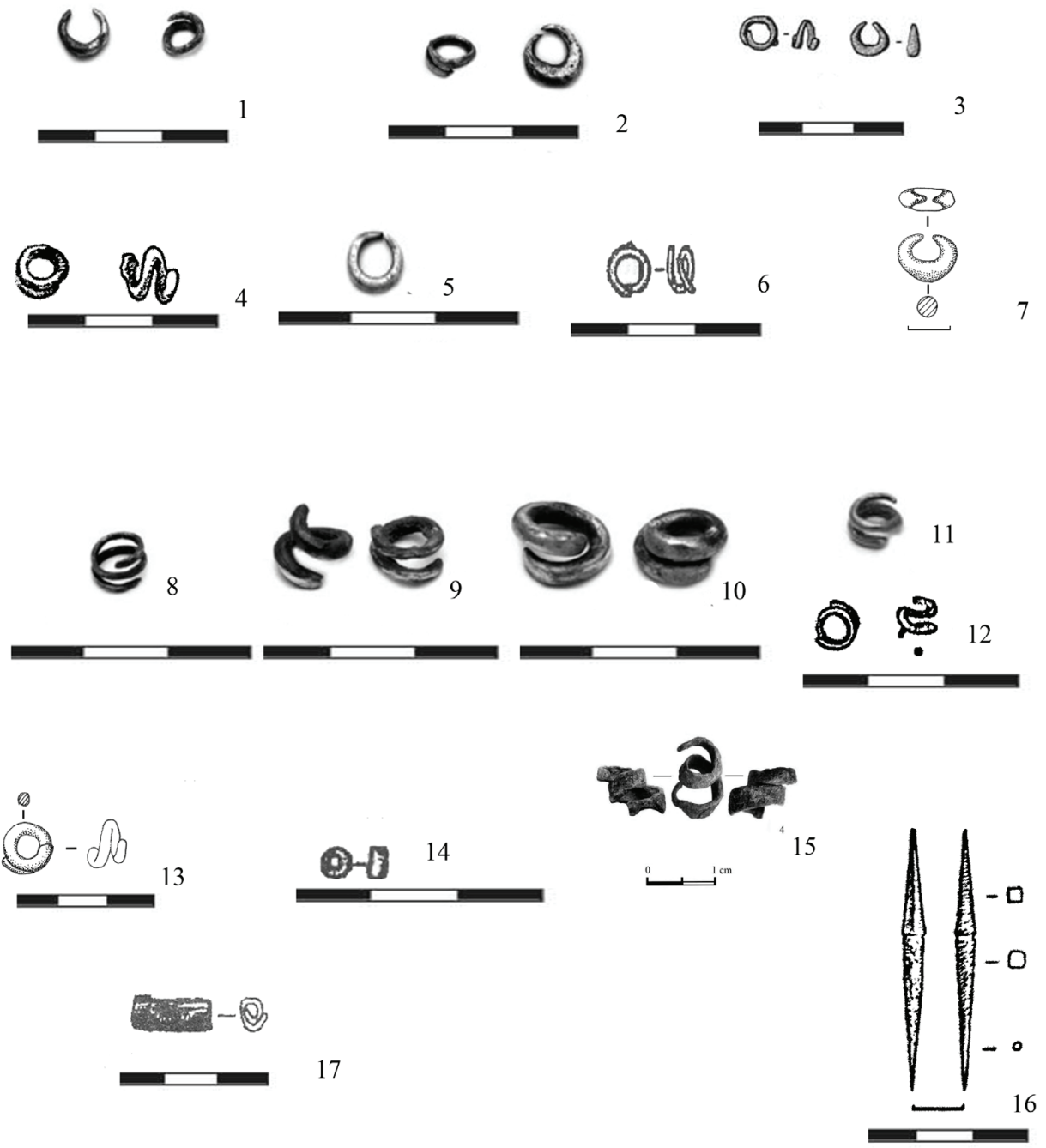

Fig. 13. Yamnaya culture metal goods in the Dniester-Prut basins

(1-10 - silver, 11-12 - gold, 13-17 - copper/bronze); 1 - Brăviceni 7/2; 2 - Corpaci 2/12; 3 Pysarivka 5/1; 4 - Brăviceni 2/8; 5 - Teşcani 1/10; 6 - Cuzmin 3/2; 7 - Orhei 1/2; 8 - Bădragii Vechi 25/12; 9 - Bădragii Vechi 13/7; 10 - Bădragii Vechi 6/7; 11, 12 - Brăviceni 4/4 (11 - photo, 12 drawing); 13 - Orhei 1/6; 14 - Cuzmin 3/2; 15 - Brînzenii Noi 1/4; 16 - Brăviceni 2/7; 17 - Mocra 1/3 [after: 1, 2, 5, 8-11, 16 - Nikulitsa 2009; 3 - Harat et al. 2014; 4, 12, 16 - Larina et al. 2008; 6, 14 - Bubulich, Khakheu 2002; 7, 13 - Dergachev 1973; 17 - Kashuba et al. 2001-2002] 


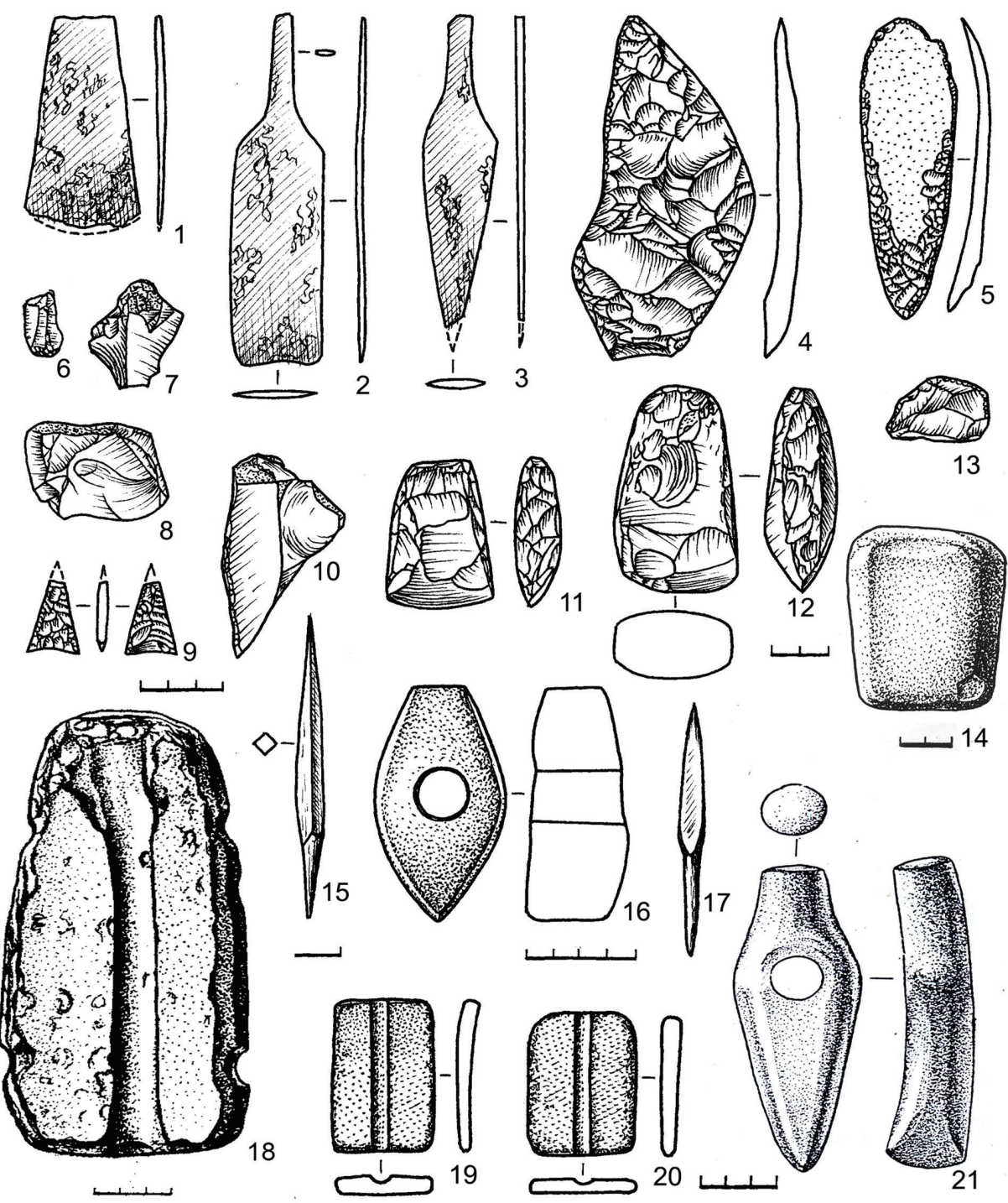

Fig. 14. Work tools from Yamnaya culture burials on the north-western Black Sea Coast (1-3, 15 - copper, bronze; 4-13 - flint, 14, 16, 18-21 - stone, 17 - bone);

1 - Alkaliya 35/6, axe; 2 - Taraclia II, 10/19, knife-razor; 3 - Frikatsey 4/12, knife-dagger; 4 - Utkonosovka 1/6, sickle; 5 - Kholmskoe 2/8, blade knife; 6 - Nagornoe 14/16, flint artifact; 7 -Vishnevoe 17/43, flint artifact; 8 - Vishnevoe 1/43, flint artifact; 9 - Congaz 11/5, arrowhead; 10 - Chaush 20/2, flint artifact; 11 - Kholmskoe 5/14, axe; 12 - Grigorievca 1/10, axe; 13 - Vishnevoe 17/43, scraper; 14 - Shevchenkovo 3/11, copper-ore grindstone; 15 - Brăviceni 7/2, awl; 16 Svetlîi 3/25, stone axe; 17 - Hlinaia 1/1, arrowhead; 18 - Chervonyi Yar I, 1/6, arrow-shaft smoother; 19, 20 - Olăneşti 6/2, arrow-shaft smoother; 21 - Alkaliya 5/6, stone axe [after Subbotin 2003] 


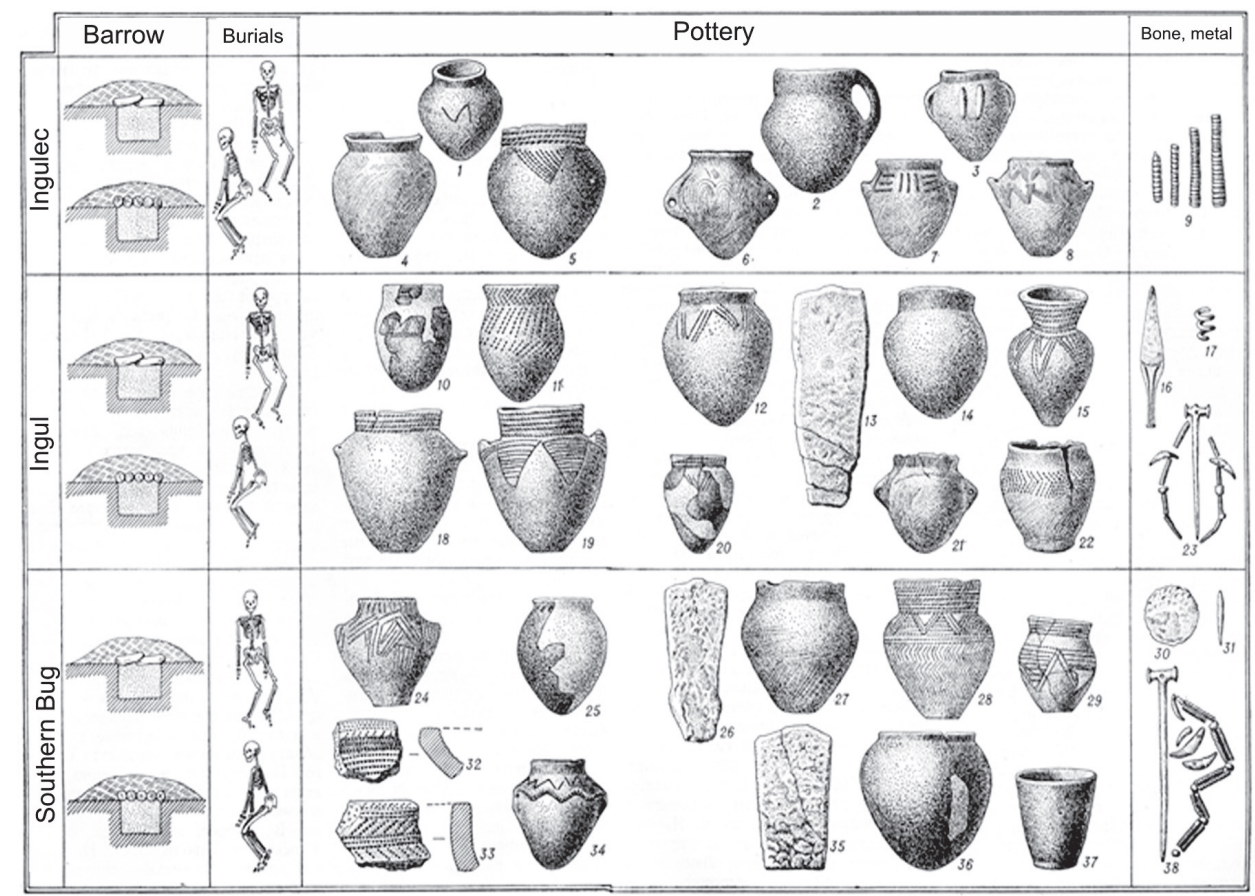

Fig. 15. Yamnaya culture materials in the Southern Bug-Inhul interfluve [after Shaposhnikova 1985]

In various regions, in comparison to other YC territories, specific rite elements or artefacts may either dominate or, on the contrary, be absent. For instance, in the Dnieper-Southern Bug interfluve, one can notice a concentration of anthropomorphic stone stelae and hammerhead pins. Stelae are known on the north-western Black Sea Coast, while pins occur there in single specimens only. The north-western Black Sea Coast stands out from the entire YC not only because of specific pottery traits or particular artefacts but also the number of graves with wooden wagons [Ivanova, Tsimidanov 1993].

The most significant inventory category is pottery. It reflects best the differences between YC (pit-grave historical-cultural community) regions and local varieties (Figs 15; 16).

The sites in the forest-steppe portion of the Dniester drainage basin are similar no doubt to those in the Prut drainage forest-steppe and may be considered a specific territorial group within the Dniester-Prut interfluve. The group is characterized by the same ritual traits and grave-goods composition as those found in the entire north-western Black Sea Coast. The structure of barrows displays the same approach to the organization of sacred space: some barrows have ditches and crom- 


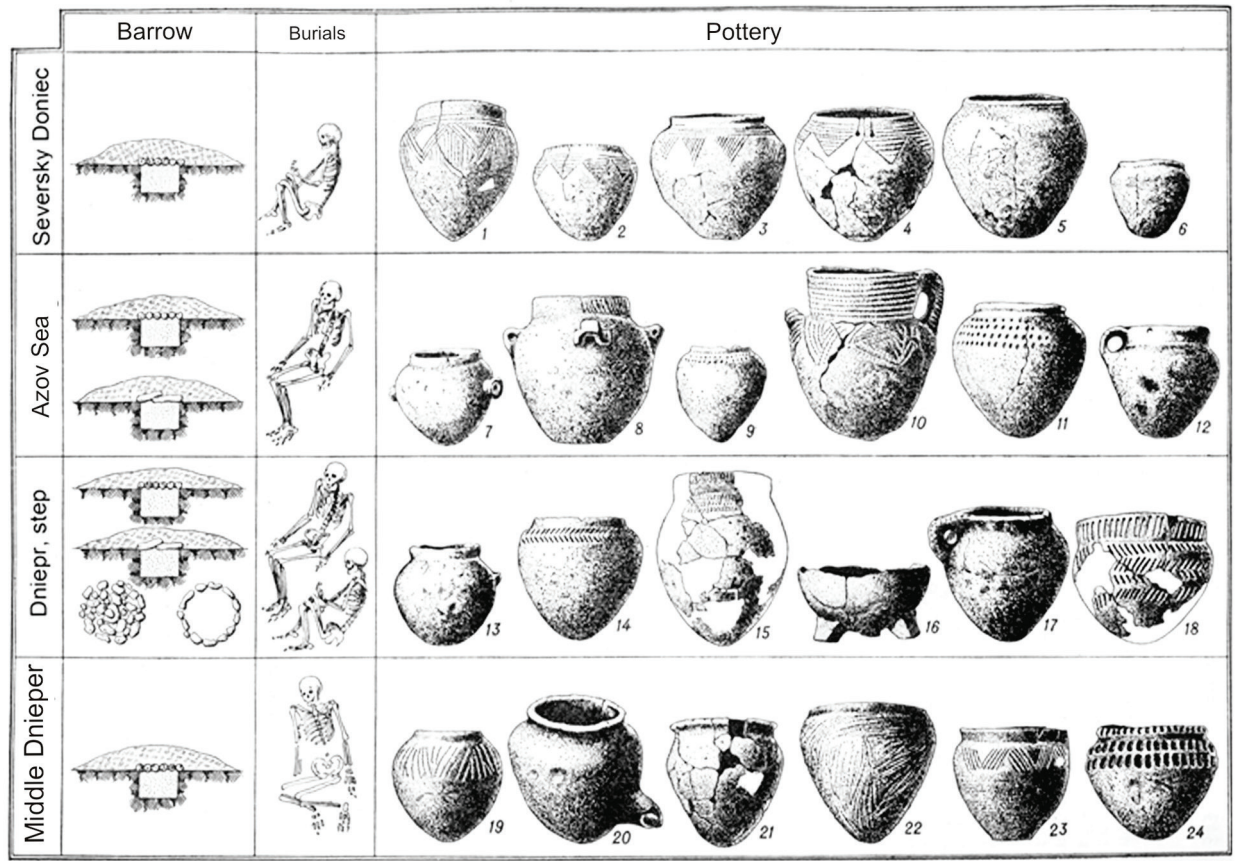

Fig. 16. Yamnaya culture Pottery in the Dnieper-Donetsk Region [after Shaposhnikova 1985]

lechs, and burials are arranged along arches or circles (Fig. 17: 1,2). The deceased were deposited in simple pits and ones with a step, with the rectangular shape of the chamber prevailing. Stone and wooden covers (placed along and across graves), and organic padding on the grave chamber bottom were used. The body arrangement variants do not differ from traditional ones. Skeletons lay crouched on their back, leaning to the left or right side, and also on their right or left side (Figs. 18$-20 ; 21 ; 19)$. Burials with disarticulated skeletons are known as well (Ocniţa 1/1, $6 / 25,3 / 17$ ). Pottery is dominated by various forms of pots (Fig. 23). There occur small amphorae, 'Budzak pots' ('jars') and pot-like vessels (Figs. 24:16,17,21-25), as well as ceramics showing connections to other cultures (Fig. 24:1-15). There are only few metal goods; they include silver, copper and gold artefacts, with ornaments dominating (Fig. 13). Finds include also work tools and weapons made of stone, bone, and flint; flint flakes are relatively common (Fig. 25). Ornaments of animal bones and teeth are encountered as well.

Generally speaking, it can be observed that materials from sites in the forest-steppe zone are more meagre in number than those from the steppes. They contain much fewer metal goods, the set of finds is more limited, there are fewer vessels as well. Out of 2,632 YC burials discovered on the north-western Black Sea Coast, 464 burials, or 17.6 per cent, are located in the forest-steppe zone of 

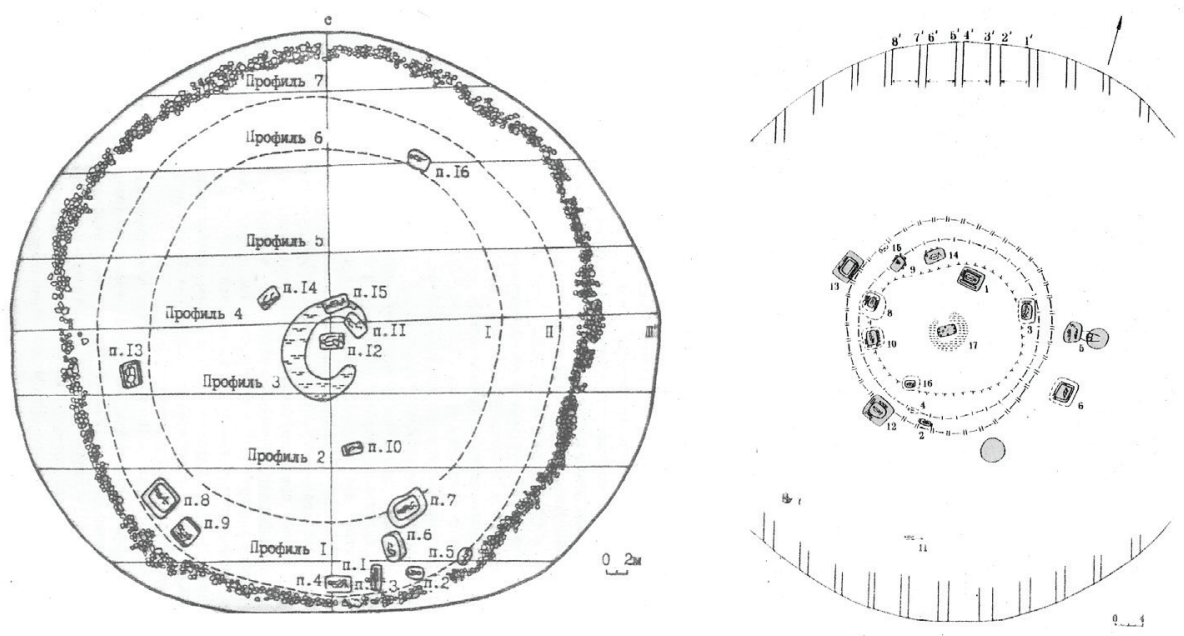

1
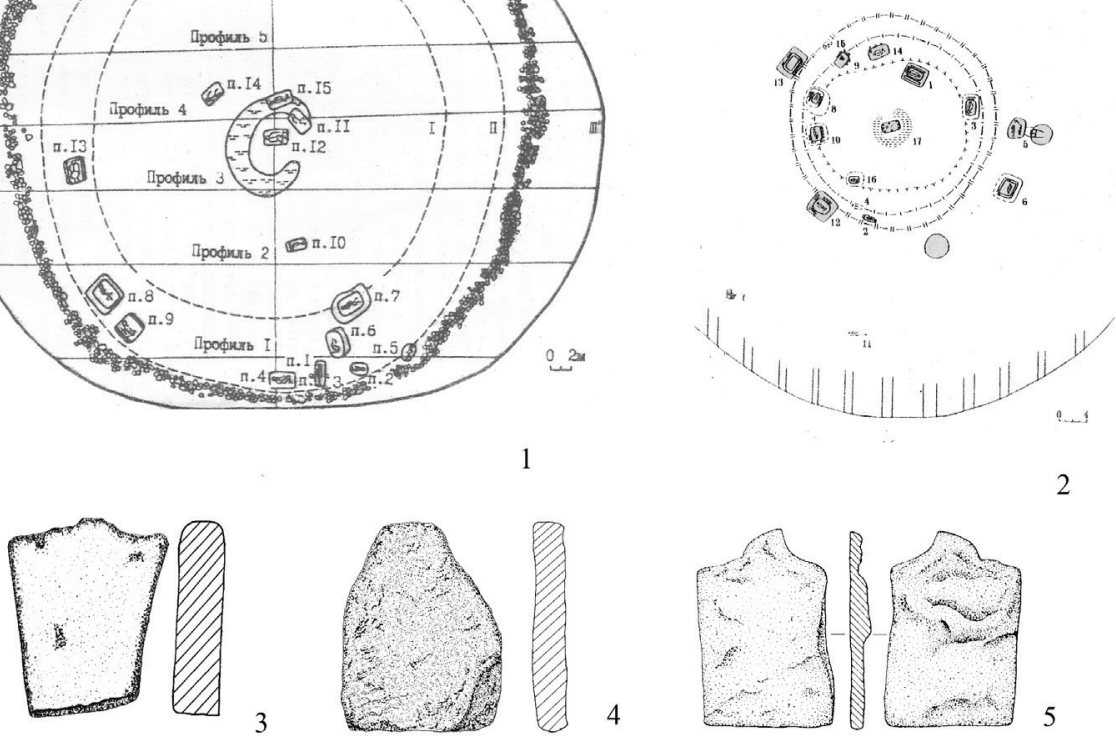

3

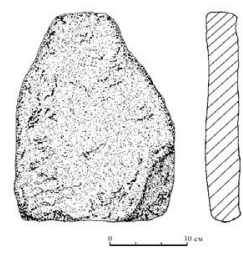

4
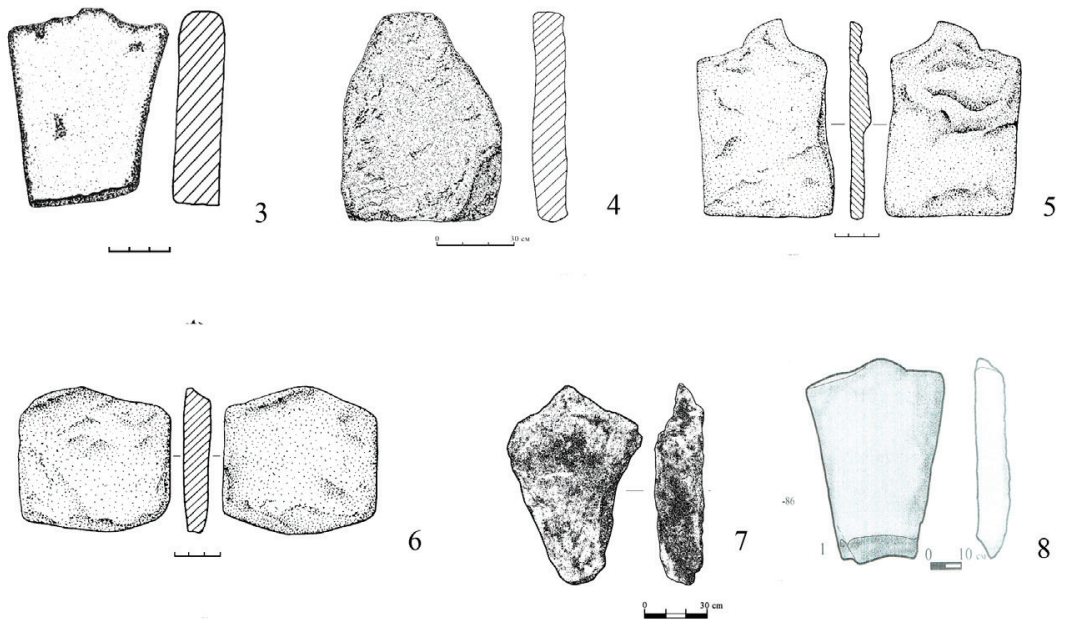

Fig. 17. Yamnaya culture barrows and stelae in the Dniester-Prut basins.

1 - Corpaci, barrow 2; 2 - Ocniţa, barrow 3; 3 - Ocniţa, barrow 4, mound; 4 - Cuconeştii Vechi 1/3; 5 - Mărculești 1/2; 6 - Mărculeşti 1/1; 7 - Brînzenii Noi, platfom at the barrow base 1; 8 - Porohy, barrow 3A, mound [after: 1 - Yarovoy 1984; 2, 3 - Manzura et al. 1992; 4 - Ketraru et al. 1975; 5, 6 - Levinskiy, Tentiuk 1990; 7 - Agulnikov, Mistreanu 2014; 8 - Klochko et al. 2015a] 

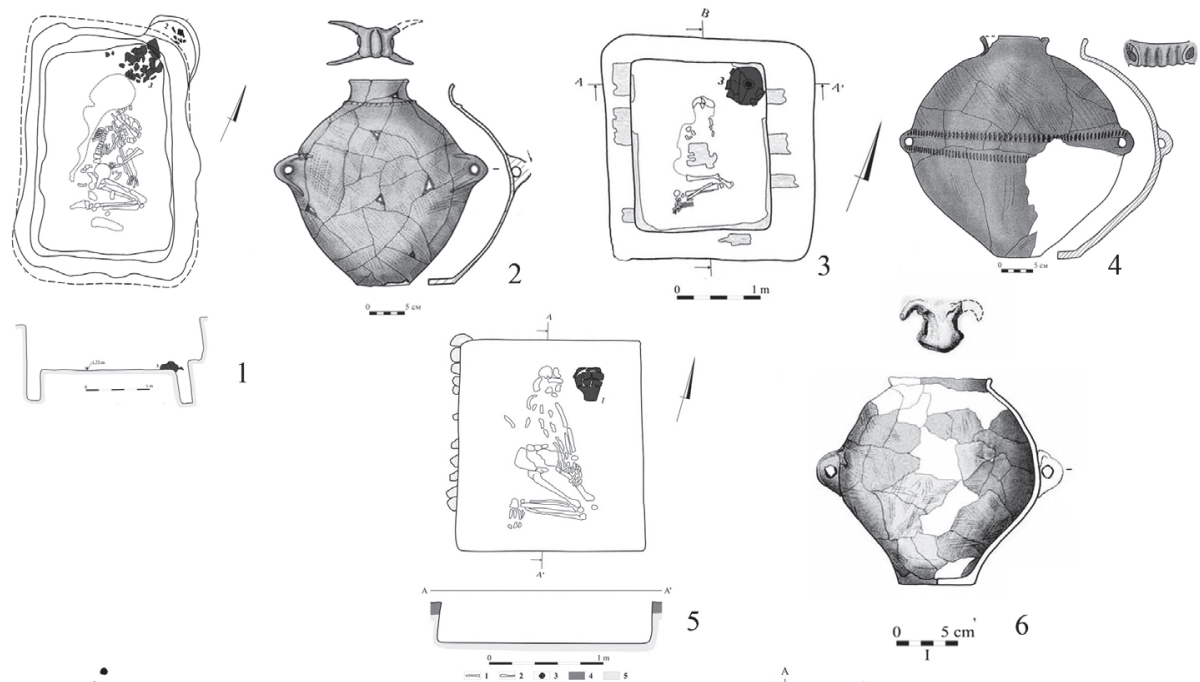

25

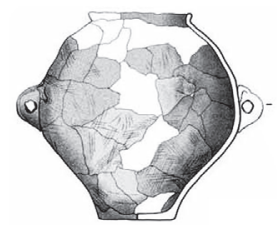

$-\frac{5 \mathrm{sm}}{2} 6$
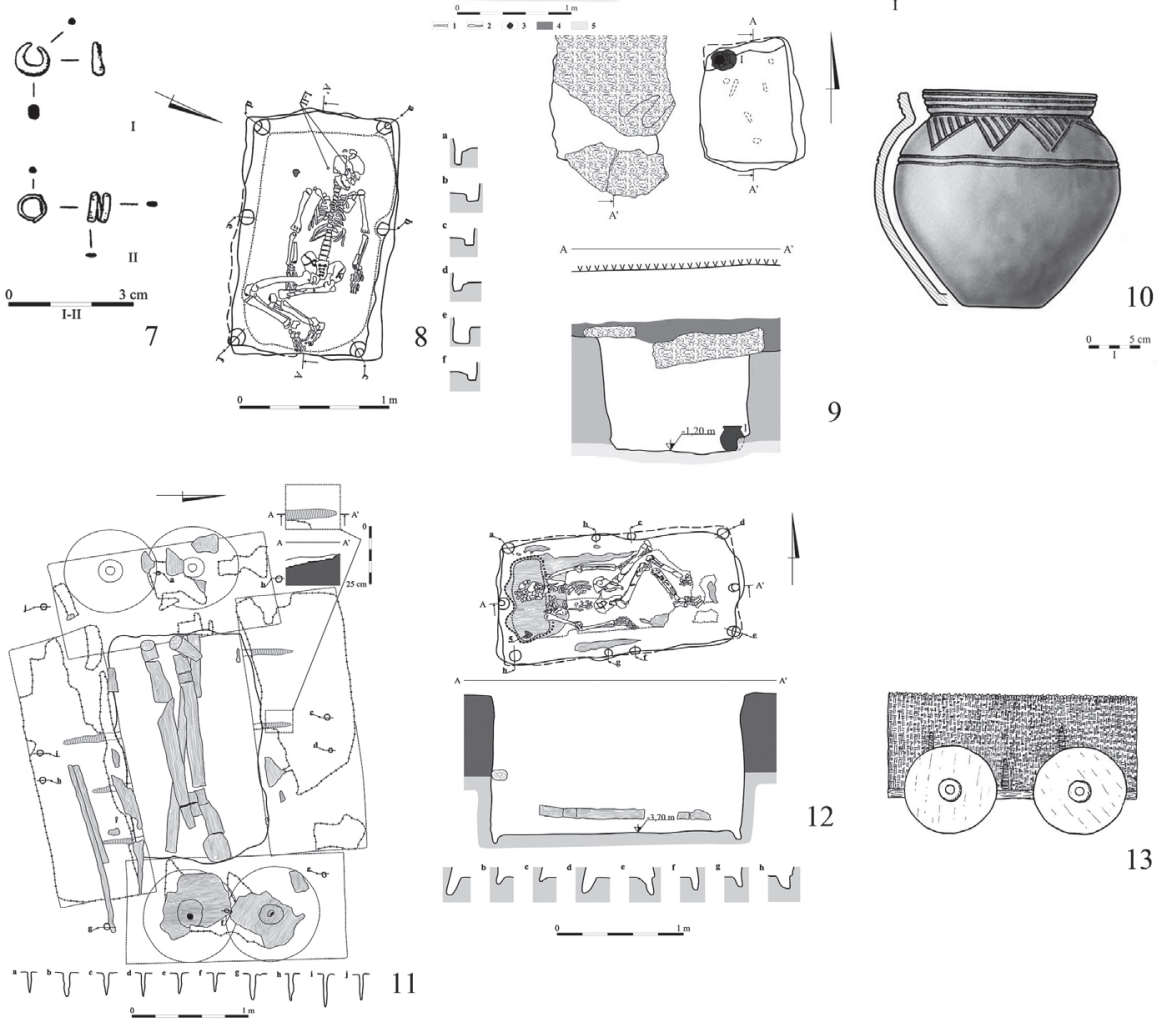

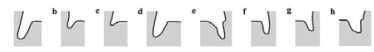

Fig. 18. Yampil Ceremonial Centre grave asemblages

1,2 - Porohy 4/8; 3,4 - Porohy 2/6; 5,6 - Porohy 3/4; 7,8 - Pysarivka 5/1; 9,10 - Pysarivka 2/3; 11-13 - Pysarivka 6/2 [after Harat et al. 2014] 

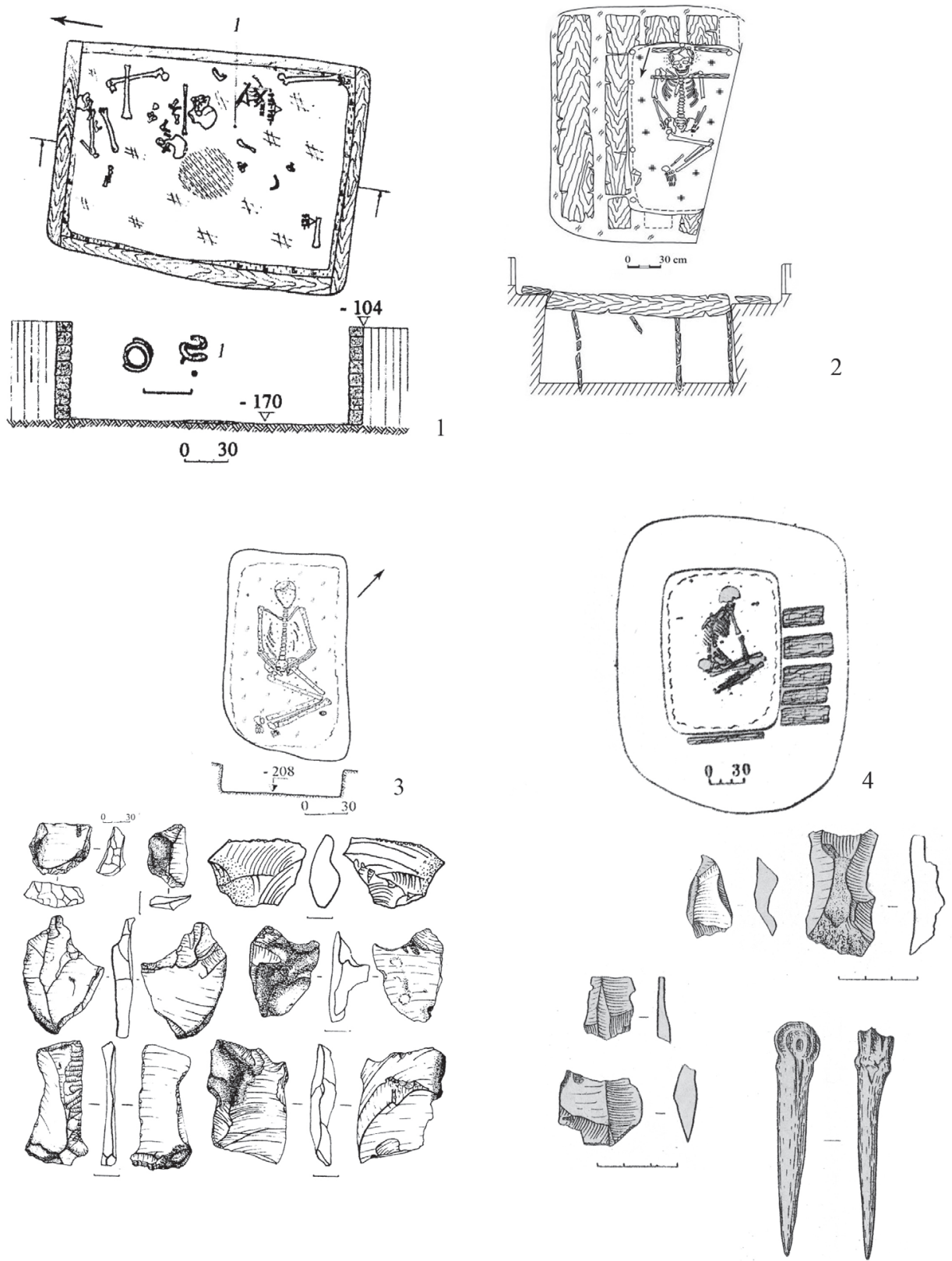

Fig. 19. Yamnaya culture funerary assemblages in the Dniester-Prut basins 1 - Brăviceni 4/4; 2 - Brînzenii Noi 1/4; 3 - Brăviceni 17/3; 4 - Ocniţa 7/8 [after: 1, 3 - Larina et al. 2008; 2 - Agulnikov, Mistreanu 2014; 4 - Manzura et al. 1992] 

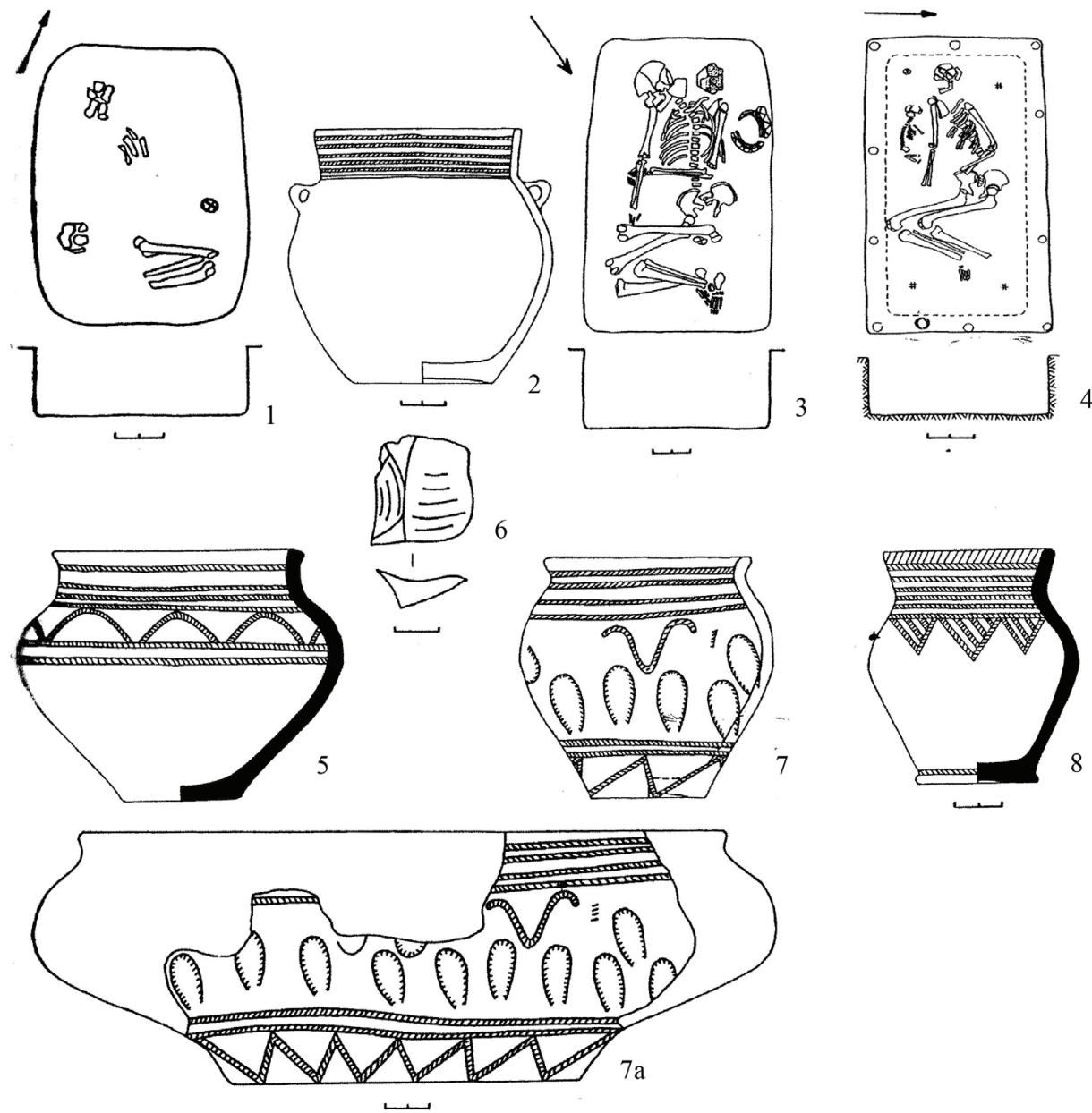

Fig. 20. Barrows 1 and 2 in the vicinity of Pererîta

1,2, 6 - burial 1/9; 3, 5, 7 - burial 1/10; 7a - vessel projection from burial 1/10; 4, 8 - burial 2/1 [after Kurchatov 2006]

the Dniester-Prut interfluve. It will be logical to assume that the major categories of finds will represent the same percentage. Of 467 vessels unearthed in the entire region, the forest-steppe zone yielded 55 items (including those recovered in the course of excavations carried out by the Yampil Expedition in 2010-2014) $)^{12}$, or 11.8 per cent. This figure is by one-third lower than expected.

The most common pottery forms on the north-western Black Sea Coast are pots

12 We do not take into account vessels found outside burials in barrow mounds (e.g. Ocniţa, barrow 3, barrow 7 and others), although their YC provenance is highly probable. 


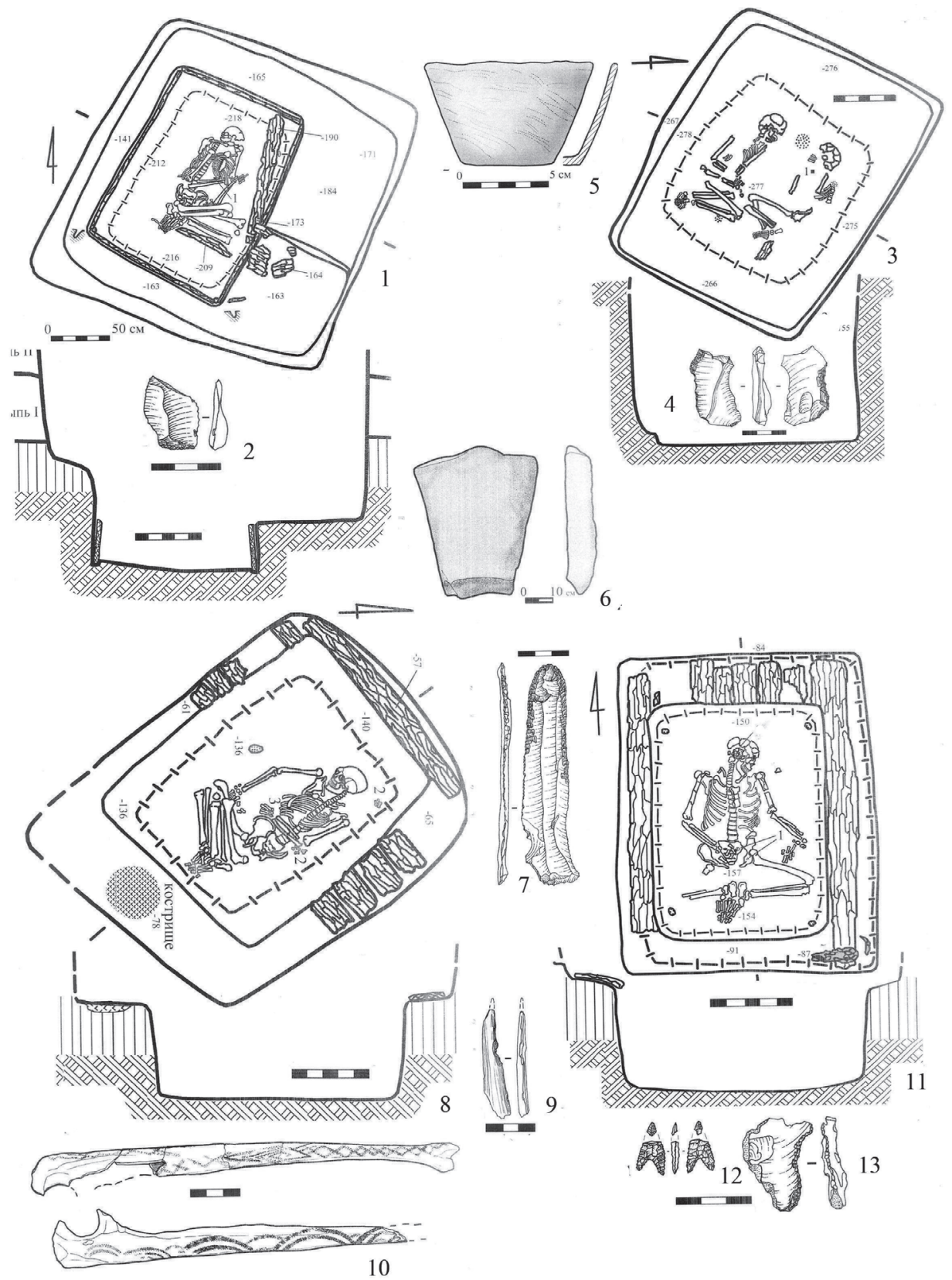

Fig. 21. Yamnaya culture burials and materials on the Dniester-Podolia (forest steppe).

1, 2 - Porohy 3A/1; 3, 4 - Porohy 3A/20; 5 - Porohy 3A/18; 6 - Porohy 3A/mound; 7 - Porohy 3A/15; 8-10 - Porohy 3A/10; 11-13 - Porohy 3A/11 [after Razumov et al. 2012; Klochko et al. 2015a] 

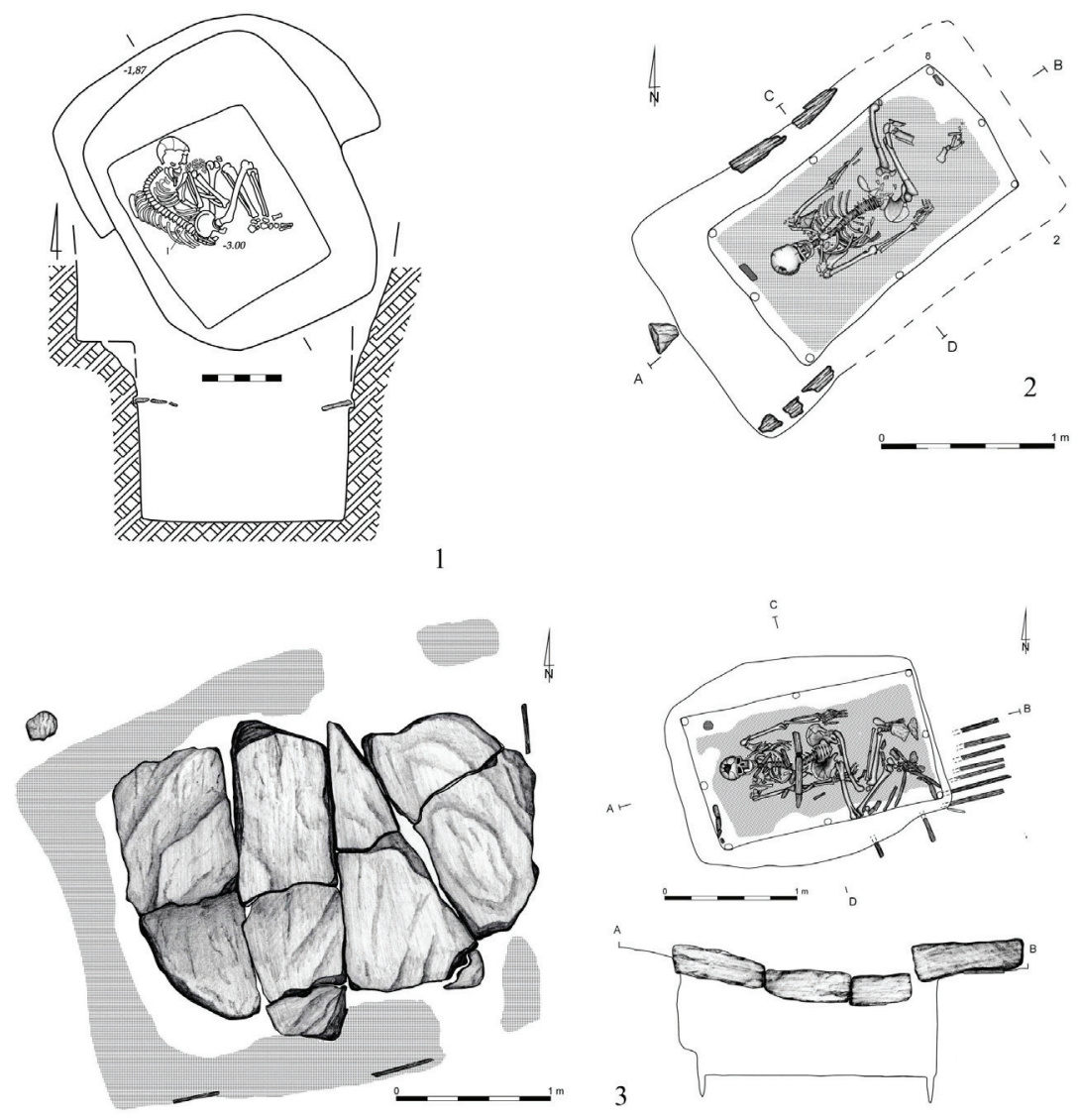

Fig. 22 . Yamnaya culture burials on the Dniester-Podolia (forest steppe)

1 - Klembivka 1/14; 2 - Prydnistryanske 4/6; 3 - Prydnistryanske 4/4 [after Klochko et al. 2015; 2015b]

(34.5\%), 'Budzhak pots' ('jars') (18\%), small amphorae and amphora-like vessels (12.2\%), bowls (12\%), large-size ('corded') amphorae (4.5\%), GAC vessels (2\%). In the Dniester-Prut interfluve, percentage shares of individual pottery forms are as follows: pots $-45 \%$, 'Budzhak pots' ('jars') and pot-like vessels $-9 \%$, small amphorae and amphora-like vessels $-4.5 \%$, and bowls $-5.5 \%$. The interfluve yielded one-third of all large-size amphorae, about two-thirds of all GAC vessels, but only one beaker (of 39 beakers and beaker-like vessels recovered on the north-western Black Sea Coast), which was found in a grave on the Pererîta 2/1 site (Fig. 20:4, 8).

Five copper (bronze) goods were unearthed, including one tool (awl) and four ornaments (Fig. 13:13-17). No large metal artefacts were encountered. Instead, 19 silver temple ornaments were found (Fig. 13:1-10), which represent 15.7 per cent of all silver goods (121 objects from 61 graves) found on the north-western 

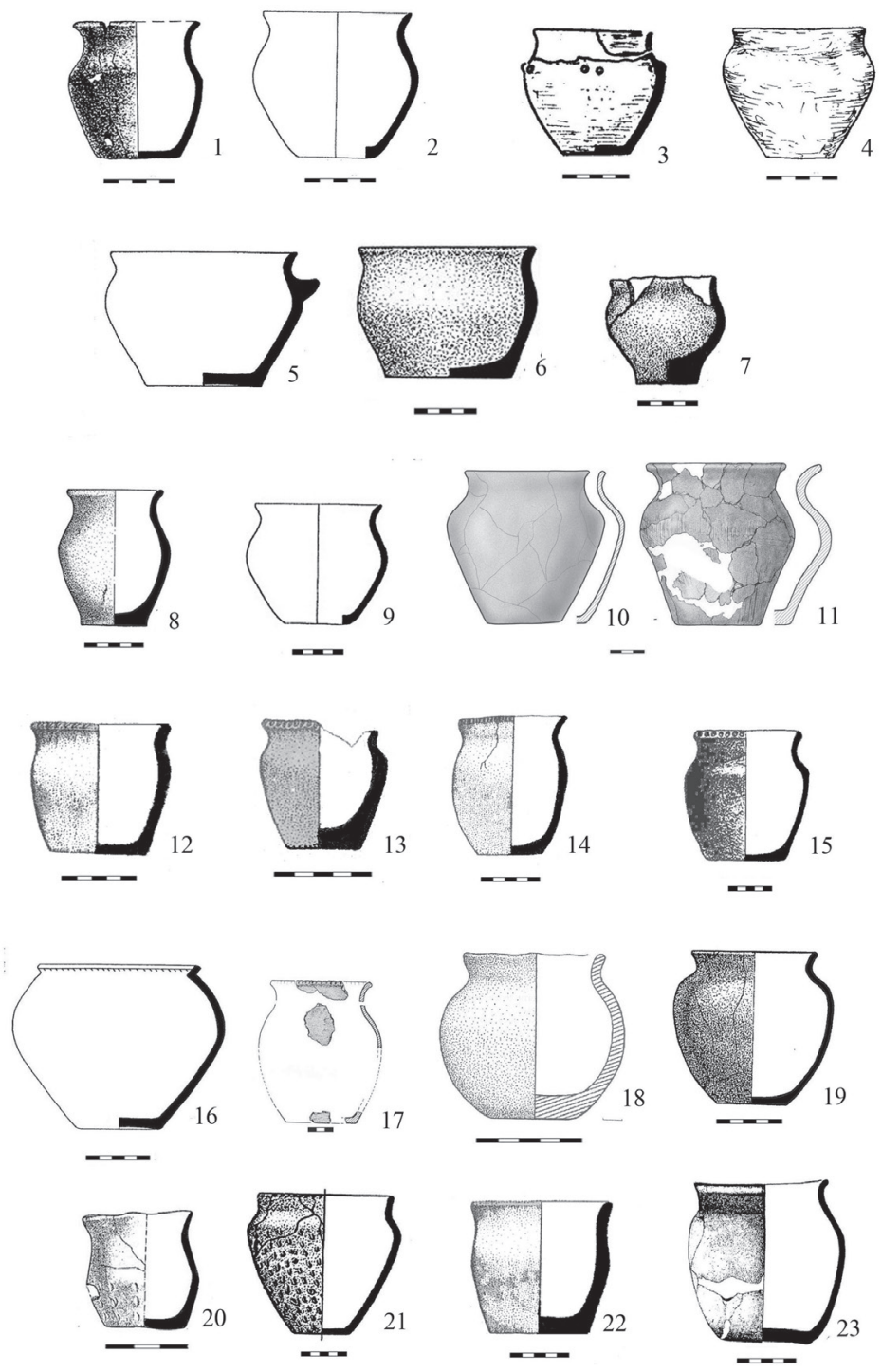

Fig. 23. Yamnaya culture pottery from the Dniester-Prut basins 1 - Chirileni 3/22; 2 - Brăviceni 16/4; 3 - Medveja 1/4; 4 - Stavchany 3/1; 5 - Pererîta 2/11; 6 - Duruitoarea Nouă 4/2; 7 - Corpaci 2/9; 8 - Brăviceni 7/13; 9 - Brăviceni 6/4; 10 - Pysarivka 5/2; 11 Pidlisivka 1/10; 12 - Ocniţa 7/4; 13 - Ocniţa 5/4; 14 - Ocniţa 5/6; 15 - Mocra 1/6; 16 - Pererîta 2/12; 17 - Severynivka 2/9; 18 - Podoima 3/6; 19 - Brăviceni 2/3; 20 - Brăviceni 1/10; 21 - Burlăneşti barrow 2, mound; 22 - Ocniţa 7/4; 23 - Brăviceni 23/3 [after: 1 - Abyzova, Klochko 2003-2004; 2, 8, 9, 19, 20, 23 - Larina et al. 2008; 3 - Savva, Dergachev 1984; 4 - Zbenovich 1967; 5, 16 Kurchatov 2006; 6 - Demchenko 2007; 7 - Yarovoy 1984; 10, 17 - Harat et al. 2014; 11 - Kośko et al. (Eds) 2014; 12-14, 22 - Manzura et al. 1992; 15 - Kashuba et al. 2001-2002; 18 - Bubulich, Khakheu 2002; 21 - Demchenko, Levitskiy 2006] 

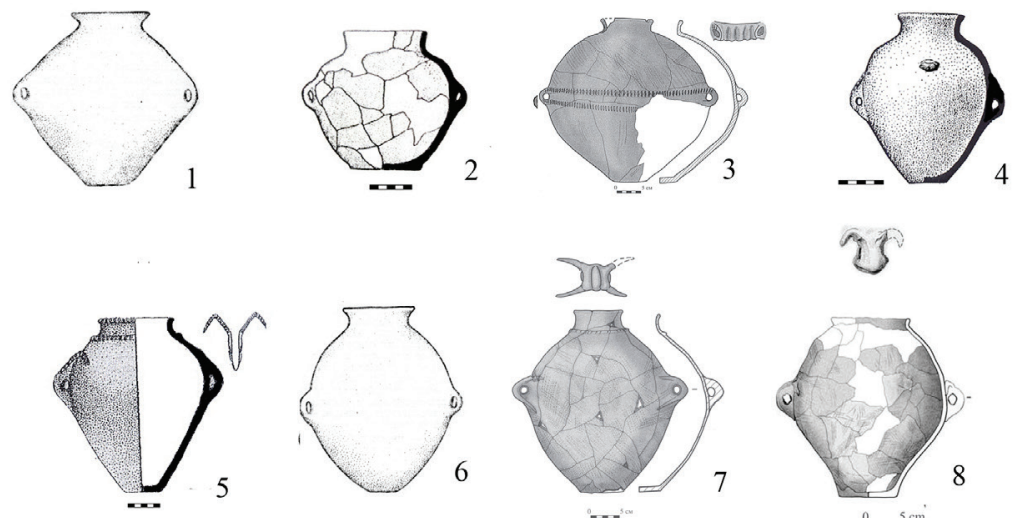

25
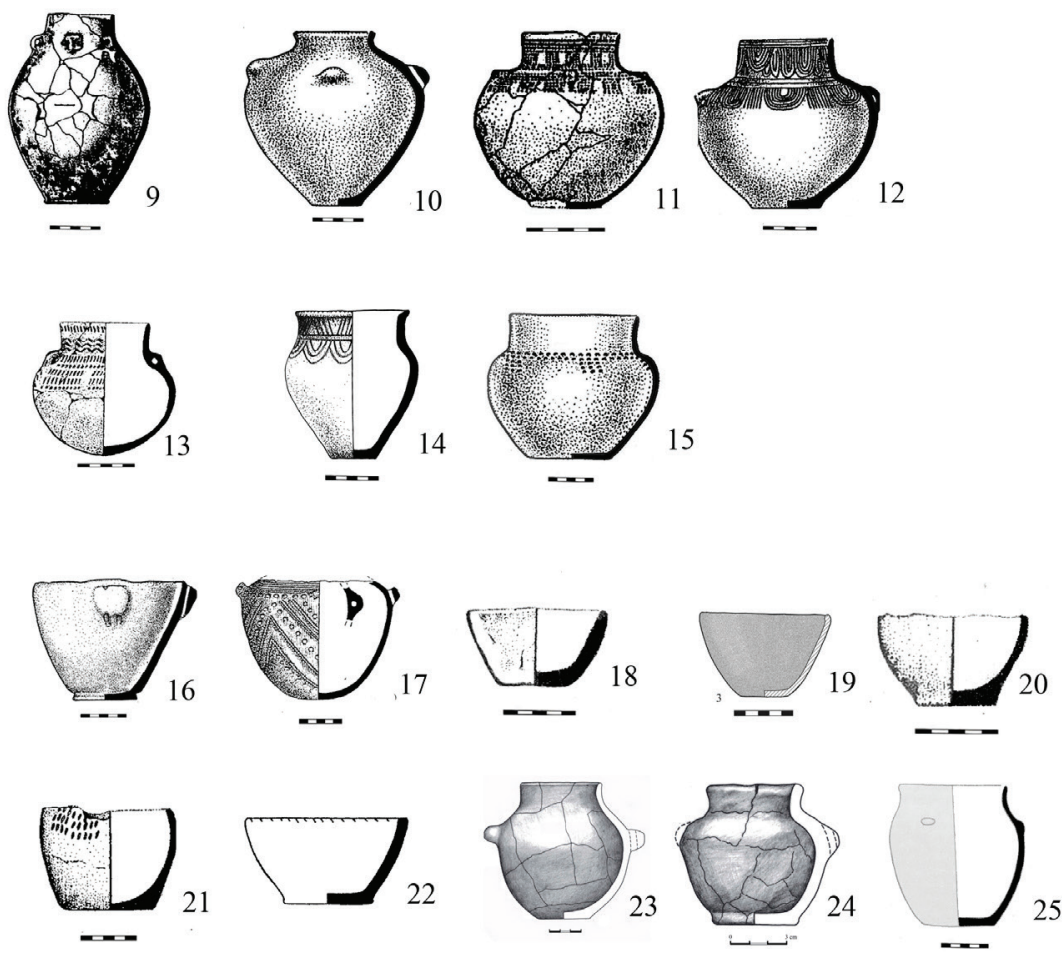

Fig. 24 . Yamnaya culture pottery from the Dniester-Prut basins

1 - Bursuceni 1/19; 2 - Iabloana 1/1; 3 - Porohy 2/6; 4 - Ocniţa 3/13; 5 - Ocniţa 6/18; 6 - Bursuceni $1 / 14 ; 7$ - Porohy $4 / 8 ; 8$ - Porohy 3/4; 9 - Mărculești 3/4; 10 - Corpaci 2/13; 11 - Ocniţa 3/14; 12 - Corpaci 2/7; 13 - Mocra 3/4; 14 - Orhei 1/3; 15 - Camenca (Kamenka) 445/7; 16 - Brăviceni 16/9; 17 - Mocra 1/3; 18 - Ocniţa 7/4; 19 - Dobrianka 1/4; 20 - Ocniţa 3/15; 21 - Ocniţa 4/4; 22 - Pererîta 2/6; 23 - Rogojeni 1/1; 24 - Rogojeni 1/2; 25 - Mîndrești 1/1 [after: 1,6 - Yarovoy 1985; 2 - Yarovoy 1983; 3, 7, 8, 19 - Harat et al. 2014; 4, 5, 11, 18, 20, 21 - Manzura et al. 1992; 9 - Beylekchi 1992; 10, 12 - Yarovoy 1984; 13, 17 - Kashuba et al. 2001-2002; 14, 25 - Dergachev 1973; 22 - Kurchatov 2006; 23, 24 - Agulnikov et al. 2004] 

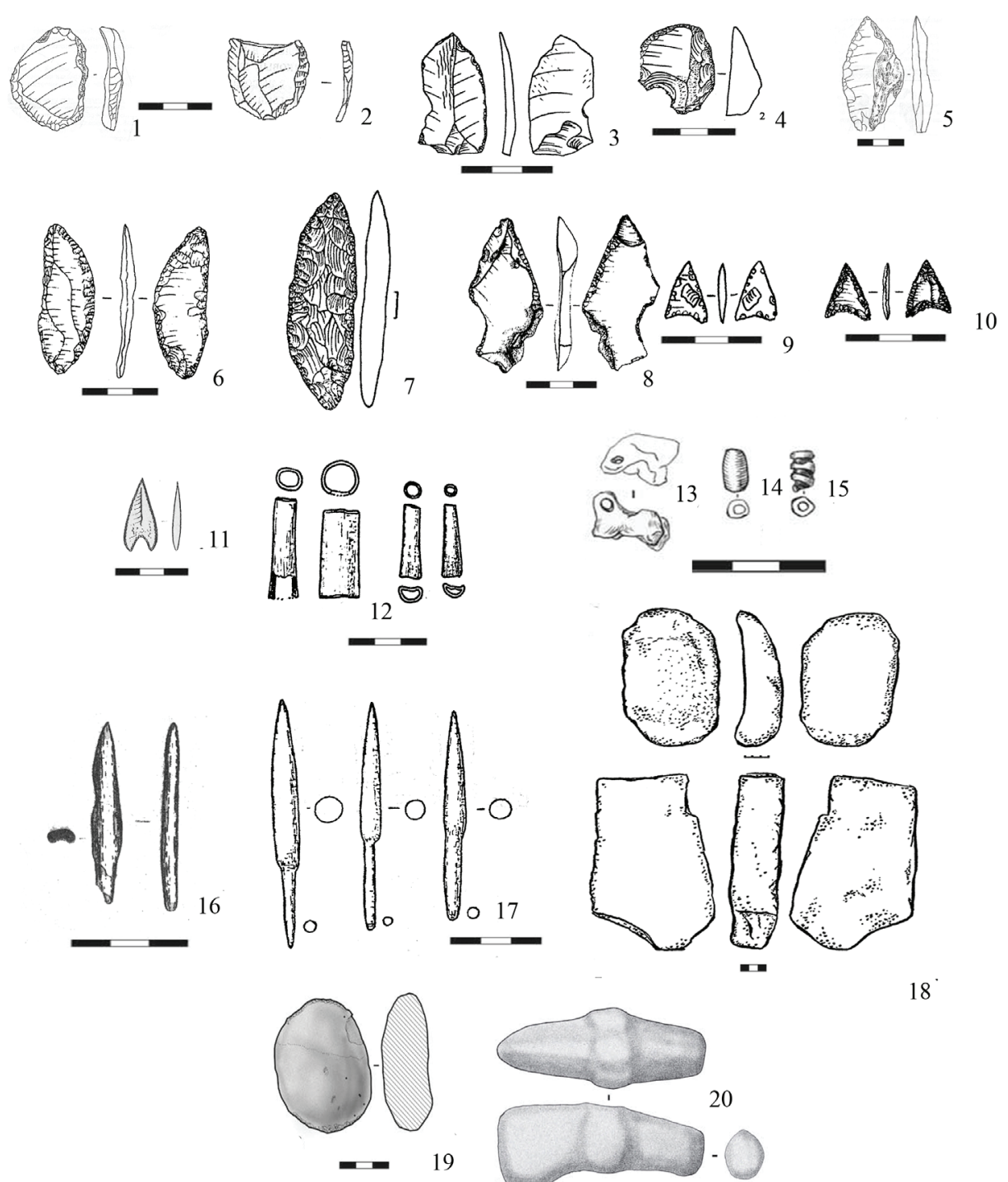

18

Fig. 25. Yamnaya culture flint, stone and bone goods in the Dniester-Prut basins

(1-11 - flint, 12-17 - bone, 18-20 - stone); 1-4 - scrapers; 5-7 - knives, 8 - blade; 9-11 - arrow points; 12 - tube-like beads; 13 - animal-tooth pendant; 14 - bead; 15 - tube-like bead with notches; 16, 17 - arrow points; 18 - quern with grindstone; 19 - hammer; 20 - semi-finished boat-axe

1 - Cuzmin 2/2; 2 - Podoima 3/8; 3 - Brăviceni, 5/7; 4 - Brăviceni, 12/7 5 - Cuzmin 2/2; 6 Brăviceni, 17/5; 7 -Brăviceni, 16/6; 8 - Brăviceni, 2/17; 9,10 - Brăviceni, 18/3; 11 - Ocniţa, 6/18; 12 - Brăviceni, 12/2, 13-15 - Pysariwka 3/2; 16 - Ocniţa, 4/2; 17 - Brăviceni, 16/9; 18 - Brăviceni, 11, kurgan mound; 19 - Dobrianka 1/4; 20 - Seweryniwka 2/10 [after: 1, 2, 5 - Bubulich, Khakheu 2002; 3, 4, 6-10, 12, 17, 18 - Larina et al., 2008; 11, 16 - Manzura et al., 1992; 13-15 - Harat et al. 2014; 19 - Harat et al. 2014; 20 - Harat et al. 2014] 


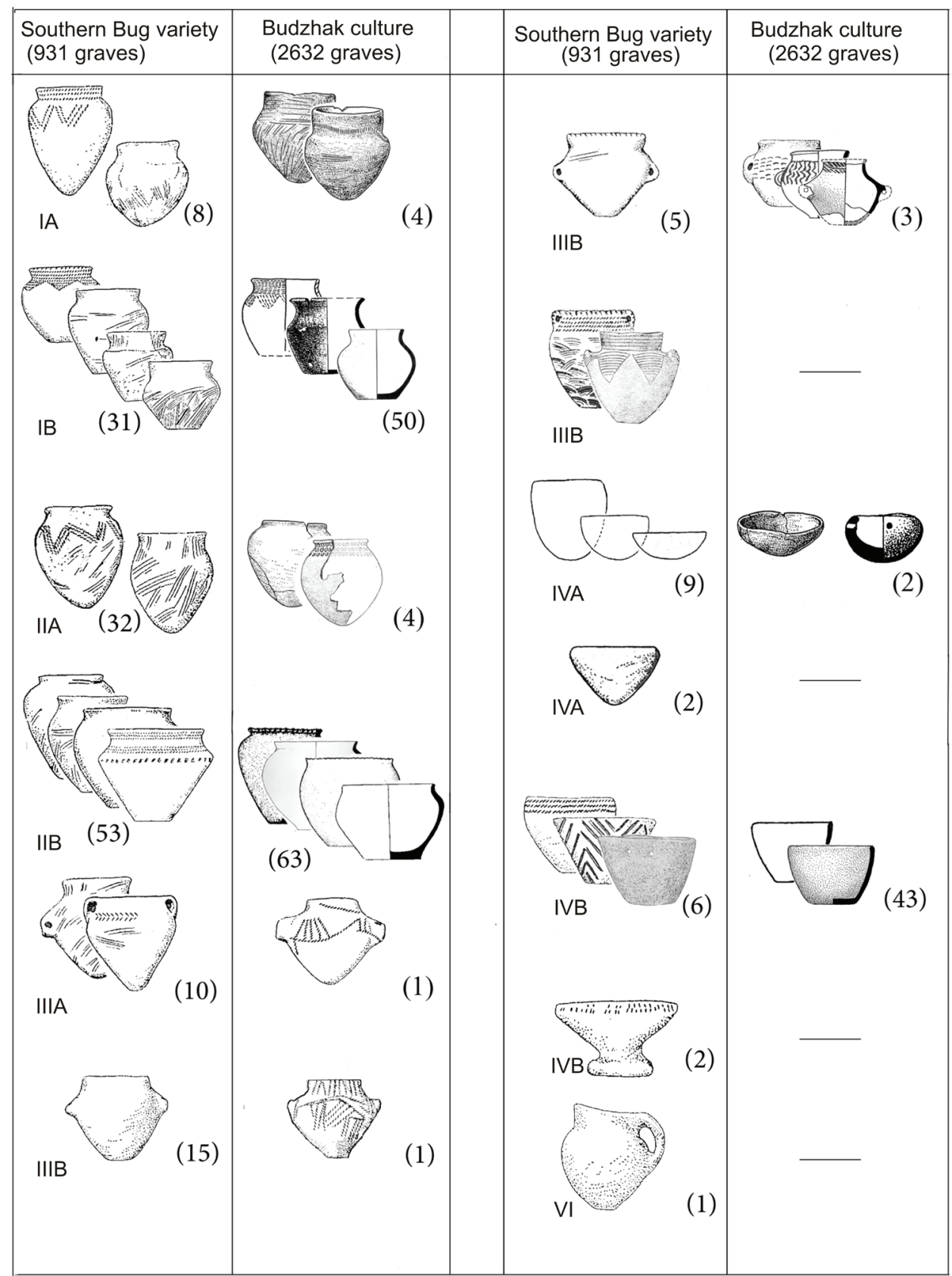

Fig. 26. Comparative analysis of the basic pottery forms of the Southern Bug variety of the Yamnaya culture [after: Shaposhnikova 1985] and Yamnaya culture vessels on the north-western Black Sea Coast (number of finds is given in parentheses) 

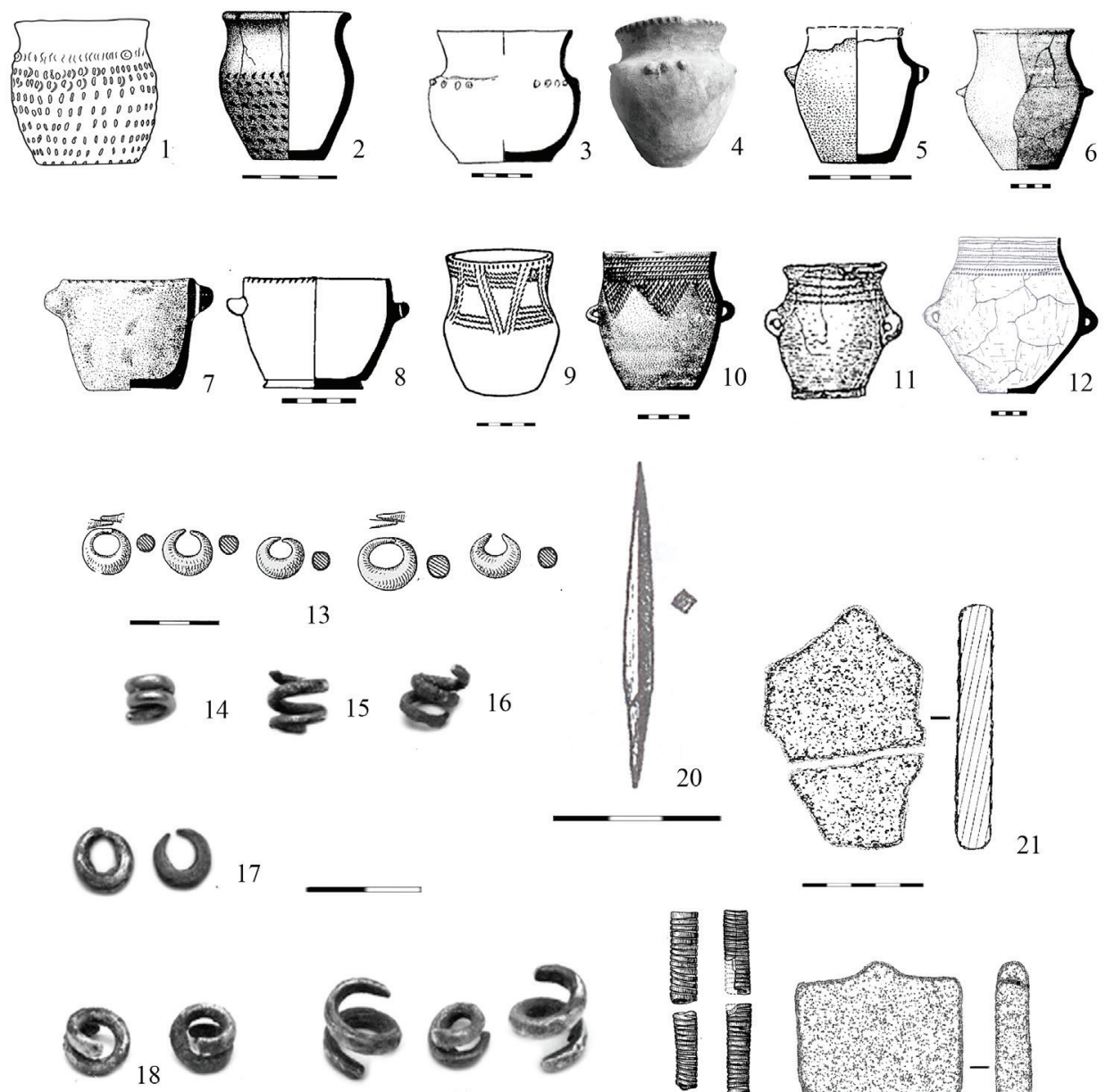

19

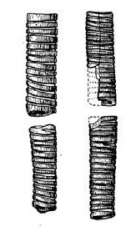

Fig. 27. Artifacts from "Carpathian copper", Yamnaya culture: 1 - Černavoda II/Foltești; 11-12 Corded Ware culture; 13 - Zimnicea; 2-10, 14-23 - Yamnaya culture (1-12 - pottery; 13-19 - silver, 20 - copper/bronze; 23 - bone)

1 - Černavoda II/Foltești II; 2 - Sărăţeni 1/4; 3 - Plavni 9/7; 4 - Petrodolinskoe 1/4; 5 - Gradeshka I, 5/2; 6 - Olăneşti 1/27; 7 -Olăneşti 1/26; 8 - Strumok 5/6; 9 - Bashtanovka 7/12; 10 - Purcari 1/28; 11 - Abtbessingen; 12 - Viktorov, barrow 8; 13 - Zimnicea; 14 - Taraclia 14/3; 15 - Tiraspol 3/18; 16 - Cazaclia 3/7; 17 - Roşcani 1/19; 18 - Talmaz 3/4; 19 - Giurgiuleşti 1/9; 20 - Frikatsey 4/12; 21 - Semenovka 8/8; 22 - Starye Beliary 1/16; 23 -Bugskiy 4/15 [after: 1 - Berciu et al. 1973; 2 - Leviţki et al. 1996; 3 - Andrukh et al. 1985; 4 - Alekseeva 1992; 5 - Subbotin et al. 1995; 6, 7, 10 - Yarovoy 1990; 8 - Vetchinnikova 1996; 9 - Shmagliy, Cherniakov 1970; 11 - Dresely, Müller 2001; 12 - Machnik 1960; 13 - Alexandrescu 1974; 14-19 - Nikulitsa 2009; 20 - Subbotin 2003; 21 - Subbotin 1985; 22 - Petrenko 1991; 23 - Shaposhnikova et al. 1986] 
Black Sea Coast. In the Dniester-Prut interfluve, one of four known gold pendants was discovered as well (Fig. 13:12). However, many silver and bronze goods are related to cemeteries, lying in the borderland between the forest-steppe and steppe (Brăviceni, Orhei).

On the north-western Black Sea Coast, including the west bank of the Southern Bug, a 2011 list comprised 123 stelae, originating from Budzhak culture burials ${ }^{13}$. In almost all instances, they were part of a grave chamber cover, only less often were they located in a barrow mound or cromlech. In those instances where the sex of the deceased was determined, the stelae were connected to male burials [Ivanova 2001: 106]. In the Dniester-Prut interfluve, such finds are few (Fig. 17:3-8).

In general terms, the pottery of the Dniester-Prut interfluve is no doubt comparable to that of the north-western Black Sea Coast. It differs from the pottery of the neighbouring Southern Bug-Inhul Region (Fig. 15); its connections to the Southern Bug drainage basin are indicated by only single finds, for instance, a vessel from the Pysarivka 2/3 burial (Fig. 18:10). Bone tube-like beads, decorated with notches, from the Pysarivka 13/2 burial (Fig. 25:15) resemble those found in the barrows of the Southern Bug YC variety (Fig. 27:23).

In this context it is appropriate to list some analogies of rare pottery forms. An 'amphora-like' vessel from the Pererîta 1/9 burial (Fig. 20:2) is similar to a vessel from Purcari 1/28 (Fig. 16:10) and to a vessel from a Late-Corded grave, the Victorov site, barrow 8 (Fig. 27:12). The latter, in turn, resembles pottery known from the Elbe and Saale drainage basins (Fig. 27:11). A burial with a similar vessel from Abtbessingen is dated to the interval of 2600-2500 BC: KI-4139, 3960 \pm 85 BP [Dresely, Müller 2001: 296, Fig. 3; 310, Fig. 17]. A vessel from a grave at Medveja 1/4 site (Fig. 23:3), bearing a pea-like relief ornament, resembles vessels from Plavni 9/7 and Petrodolinskoe 1/4 (Fig. 27:3, 4). An amphora-like vessel from Mîndreşti 1/1 (Fig. 24:25) shows similarities to vessels from Olăneşti 1/27 and Gradeshka I, 5/2 (Fig. 27:5, 6). Dents decorating the surface of a vessel found in the mound of barrow 2 in the Burlăneşti cemetery and that of another vessel from Brăviceni 1/10 (Fig. $23: 20,21)$ find analogy in a vessel from Sărăţeni $1 / 4$ and pottery belonging to the Folteşti II cultural group (Fig. 27: 1,2). A pot-like vessel ('jar') with a marked bottom and notches on the lip edge from the Pererîta $2 / 6$ site (Fig. 24:22) bears likeness to pottery from Olăneşti 1/26 and Strumok 5/6 (Fig. 27:7, 8) ${ }^{14}$. What differs them is the absence of handles. On the lip of a beaker from the Pererita 2/1 site (Fig. 20:8), there are notches; this ornament was found on only one more beaker: in a burial from the Bashtanovka 7/12 site (Fig. 27:9). There are also pots with lip notches: Ocniţa $5 / 4,5 / 6,7 / 4$, Mocra 1/6 (Fig. 23:12-15). This lip ornament is rather common on pottery from the lower Danube Region; on the north-western Black Sea Coast, about 30 per cent of pots bear notched, pinched or dented ornaments on their lip edges.

13 I wish to thank Mr. Popovich for making information from his personal archive available to us.

14 Grave Strumok 5/6 belongs to the BC. 
In the Dniester-Prut interfluve, as on the entire north-western Black Sea Coast, craftsman graves are found in which various flint and bone tool kits are discovered (Fig. 19:3, 4), but only rarely are they subjected to a use-wear analysis. Consequently, it is not always possible to determine the craft practised by the deceased. One example of a successful determination is that of a craftsman from Brăviceni 17/3, who, it transpired, worked with wood (Fig. 19:3).

Anthropomorphic stelae resemble other specimens from the north-western Black Sea Coast, too (Fig. 27:21, 22). Spiral temple pendants made of various metals (Fig. 13) do not differ at all from the other ornaments of this type found on the north-western Black Sea Coast (Fig. 27:14-16, 18, 19). They are twisted both clockwise and anticlockwise. Silver crescentic pendants resemble the 'Zimnicea type' and are known from the eponymous site (Fig. 27:13) and graves on the north-western Black Sea Coast, for instance, Roşcani 1/19 (Fig. 27:17). A copper awl from Brăviceni 2/7 (Fig. 13:16) shows similarity to an awl from Frikatsey 4/12 (Fig. 27:20).

A diagnostic trait is provided by burials with holes in the grave chamber bottom, which may be the traces of mortuary houses (Figs. 18: 8, 12; 21:11;22:2, 3). Various arrangements of such holes were recorded in over $150 \mathrm{YC}$ graves on the north-western Black Sea Coast [Ivanova 2001]. Postholes are known from 11 graves in the Ocniţa cemetery and six Yampil Complex burials (Severynivka, Pysarivka, including Pysarivka 6/2 - burial with a wagon) [Manzura et al. 1992; Harat et al. 2014]. One such burial was located in the Porohy $3 \mathrm{~A}$ barrow and two others on the Prydnistryanske 1 site, barrow IV [Klochko et al. 2015]. Nineteen more graves featuring this trait of the funerary rite were recorded on the other forest-steppe sites. As a rule, the postholes are empty, which suggests that after some time the structure may have been taken down. Only in single cases were post remains observed. A unique case was recorded on the Brînzeni Noi 1/4 site where posts have survived intact (Fig. 19:2). A further detail needs to be stressed, namely that with the traditional domination of four-post structures (and the presence of four holes in the pit bottom), Yampil barrows usually feature eight to ten holes.

The funerary rite and grave goods encountered on Dniester-Prut interfluve sites show also other rather peculiar traits. Above all, one should mention here grave chamber boarding. In the barrows on the Ocniţa cemetery, boarding was recorded in five burials. In three (Ocniţa 3/13, 6/13, 6/27), boards were fastened vertically, in Ocniţa 6/9, boarding resembled a horizontal log structure, while Ocniţa 3/6 featured a wooden chest separated from grave chamber walls by a stone filling. The authors of the excavations presume that this funerary rite element is a local peculiarity of YC sites on the middle Dniester [Manzura et al. 1992: 89]. Grave wall boarding was also found in the Porohy $2 / 6$ burial, while a deep ditch (approx. $0.5 \mathrm{~m}$ ), circumventing the grave chamber, was discerned in Porohy 4/8 [Harat et al. 2014]. Recent investigations have added a burial to the unique series of wooden chest features, namely Porohy 3A/1 (Fig. 21:1). In this case, the encircling ditch 
was not deep, in contrast to other similar features, and the boards have survived up to the height of $0.6 \mathrm{~m}$ [Klochko et al. 2015; 2015a].

This group can be expanded by several other sites. In the Brăviceni 4/4 burial, walls were faced with horizontal roughed-out $\operatorname{logs} 8-10 \mathrm{~cm}$ thick (Fig. 19:1). In the Duruitoarea Nouă $4 / 3$ burial, the grave chamber was encircled by a shallow ditch ( $5 \mathrm{~cm}$ wide and deep), in which decayed wood was found but no traces of boards on chamber walls.

Outside the Dniester-Prut interfluve, only a grave from the Tiraspol 3/19 site must have been furbished with a vertical boarding; its impressions and remains have been preserved in the fill. The ditch was approx. $0.5 \mathrm{~m}$ deep while its width was 0.15-0.20 m [Savva 1988: 52]. There are also known burials with ditches running along the grave chamber circumference (Semenovka 1/6, Trapovka 4/13, Ursoaia 1/1). As a rule, they are not very wide and deep. Hence, it is believed that they encircled the bier and are not related to wall boarding [Subbotin 2000: 357]. In the steppe zone, there are cases of padding walls with rush mats or vertically arranged rush stalks (Revova 3/15, Nerushay 9/31,32). Possibly, this fact points to different homestead varieties in the steppe and forest-steppe zones.

Unique on the scale of the entire north-western Black Sea Coast, spiral copper pendants from Brînzeni Noi 1/4 (Fig. 13:15) were made, unlike all other metal pendants, from a flat band and not a round-section wire. From the Pysarivka 3/2 feature, a bone pendant with thread notches was recovered - the only such specimen in the entire region (Fig. 25:15) [Harat et al. 2014:118]. On the north-western Black Sea Coast, only six graves yielded bone arrowheads, two such graves (Brăviceni 16/9, Ocniţa 4/1) are located in the Dniester-Prut interfluve (Fig. 14:16, 17). In six north-western Black Sea Coast barrows, querns were found, while a find of a quern and grindstone as a set was recorded in barrow 11, Brăviceni cemetery (Fig. 25:18). A semi-finished boat-axe from Severynivka 2/10 (Fig. 25:20) is the only of its kind and is compared to the axes of the Donetsk CC [Razumov 2014: 345]. The graves located on the north-western Black Sea Coast have yielded four semi-finished axes but they are not linked to the CC. Two axes (Semenovka 8/16; Alkaliya 5/6) were called 'Yamnaya-Catacomb of the Akkerman type' by V.I. Klochko. ${ }^{15} \mathrm{~A}$ semi-finished axe showing CC traits has been found for the first time. The recycling of Late Palaeolithic flints, in particular a core from the Pidlisivka 1/11 burial, is remarkable. The present authors know of a single case of recycling a tool from the Stone Age, but it is associated with the CC (Dumeni $1 / 9$ grave).

Researchers working on it are absolutely right to mark out the compact territory of the Yampil Barrow Complex as a 'ceremonial centre' [Kośko, Razumov 2014: 341]. As the criteria for the distinction serve its peculiar traits vis-à-vis the Upper Dniester Area [Włodarczak 2014: 317-324].

15 We wish to thank Prof. V.I. Klochko, for consultation and the taxonomic designation. 
In Archaeological Typology, L.S. Klein gives the following definition of the variety of an archaeological culture: a part of an archaeological culture formally (typologically) distinguished, relying on distinct materials, either different or partly different from others, originating with a certain group of features [Klein 1991: 392]. The Yampil Complex (understood broadly as comprising barrows and barrow cemeteries lying the closest) does not display any clearly distinct traits that are found to exist between two neighbouring YC varieties, for example, between the north-western Black Sea Coast (which was called a separate south-western YC variety by N.Y. Merpert) and the Southern Bug-Inhul interfluve (where the sites of the Southern Bug variety, distinguished by O.G. Shaposhnikova, of the YC are located). In our opinion, therefore, a more adequate name is Yampil (Podolia) territorial centre and not $\mathrm{YC}$ variety.

On the north-western Black Sea Coast, we have distinguished four such territorial centres characterized by a greater concentration of 'rich' or 'prestige' graves [Ivanova 2001]. What makes them special is the accumulation of prestige grave goods and funerary rite traits in single barrows, barrow groups or microregions. Above all, these are remains of wooden wagons, silver temple pendants, special grave structures ('mortuary houses'), such as holes in the bottom of a grave chamber or on its step, as well as metal goods. These centres extend around the barrow cemeteries of Yasski-Mayaki, Kholmskoe, Nicolscoe, Taraclia-Balaban. It would be wrong to presume that all such finds are concentrated in these centres only: YC sites, as well as richly furnished burials are distributed across the north-western Black Sea Coast. Nevertheless, there are quite clear concentrations of 'prestige' barrows; they are related to burials with diverse inventories which give the centres their peculiar character. The division of some finds within the centres is rather uniform (polished stone shaft-hole axes, manufacturing tool kits). In each centre, however, specific weapon, ornament and ritual artefact categories can be distinguished.

For instance, in the lower Dniester drainage basin (Yasski-Mayaki barrow centre), more often than in other such clusters, bronze knives and copper awls were found. There were no barrows with astragals, shell pendants or bone beads. Among the finds of metal goods, silver spirals - but not copper or bronze ones - deserve to be mentioned, with solid copper bracelets or ones made from curled-up copper beads being encountered nonetheless. The finds of weapons are dominated by flint shaft-hole axes. The centre is associated with the finds of three wooden wagons.

Upstream the Dniester, another concentration of prestige objects is found close to the Nicolscoe barrow cemetery (on the river's left bank), known for the find of a wooden wagon. There are no flint arrow or spear points, but there are bone ones instead. Less often than in other centres, discoveries are made of metal knives, with awls not being encountered at all, but a set of a knife and an awl did occur once. There were twice as few silver spirals found than in the centre located further south (Yasski-Mayaki), but copper ones, instead, are more frequent than in other centres. More often than in other centres, too, pendants made from animal teeth 


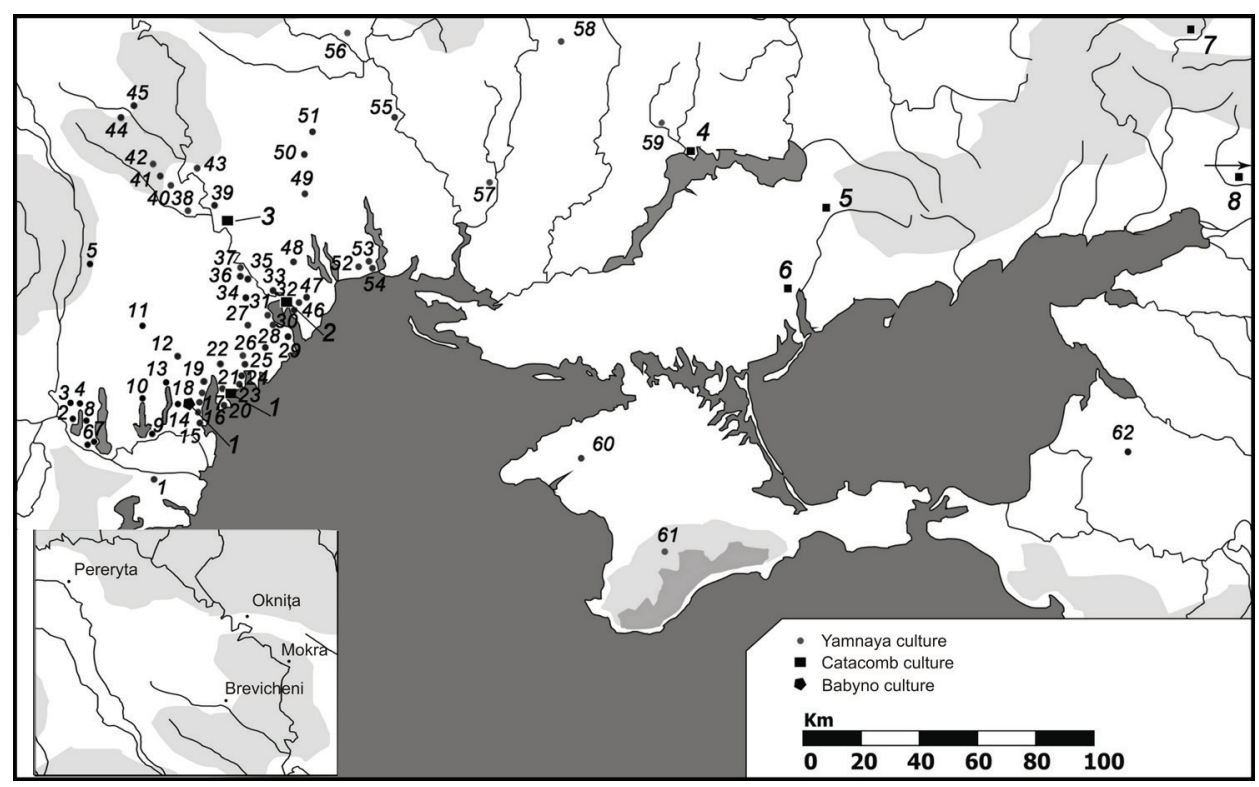

Fig. 2 8. Map of the finds of "Budzhak pots (jars)" and jar-like vessels

Yamnaya culture 1 - Independenţa/Murighiol (Romania); 2 - Frikatsey; 3 - Giurgiuleşti; 4 - Etulia; 5 - Sărăţeni; 6 - Gradeshka; 7 - Plavni; 8 - Nagornoe; 9 - Kislitsa; 10 - Novokamenka; 11 - Svetlîi; 12 - Kholmskoe; 13 - Dzinilor; 14 - Chervonyi Yar; 15 - Primorskoe; 16 - Nerushay; 17 - Glubokoe; 18 - Strumok; 19 - Bashtanovka; 20 - Trapovka; 21 - Novoselitsa; 22 - Belolesie; 23 - Vishnevoe, 24 - Zholtyi Yar; 25 - Liman; 26 - Diviziya; 27 - Sergeevka; 28 - Alkaliya; 29 Mologa; 30 - Sadovoe; 31 - Semenovka; 32 - Efimovka; 33 - Yasski; 34 - Caplani; 35 - Olăneşti; 36 - Răscăieţii Noi; 37 - Purcari; 38 - Ursoaia; 39 - Nicolscoe; 40 - Roșcani; 41 - Gura Bukului; 42 - Chirca; 43 - Corjova; 44 - Crasnoe; 45 - Brăviceni; 46 - Novogradkovka, Dobroaleksandrovka; 47 - Novaya Dolina; 48 - Scherbanka; 49 - Velikoziminovo; 50 - Revova; 51 - Grigorievka; 52 Vapniarka; 53 - Starye Beliary; 54 - Sychavka; 55 - Kovalevka; 56 - Konstantinovka; 57 - Baratovka; 58 - Krivoy Rog; 59 - Ordzhonikidze; 60 - Krasnoyarskoe; 61 - Chistenkoe; 62 - Ovalnyi.

Catacomb culture 1 - Vishnevoe; 2 - Beliaevka; 3 - Tiraspol; 4 - Kruglaya Mogila, 5 - Vinogradnoe; 6 - Vladimirovka; 7 - Zhelobok; 8 - Kastyrskiy

Babyno cultural circle 1 - Strumok

and shells are encountered. It is here, too, that two of the three hammerhead pins were recovered.

In the coastal part of Budzhak (Kholmskoe barrow centre), three burials with wagons were discovered. Weapons are dominated by flint arrow and spear points. Metal knives occur but awls are absent. Animal tooth and sell pendants are rare; more often than in other centres, silver temple pendants, copper bracelets, copper temple pendants made from tube-like beads and clasps are recorded.

In the centre which took shape near the Taraclia-Balaban cemeteries, finds embraced four wagons, two stone shaft-hole axes, a set of a knife and awl, an awl 

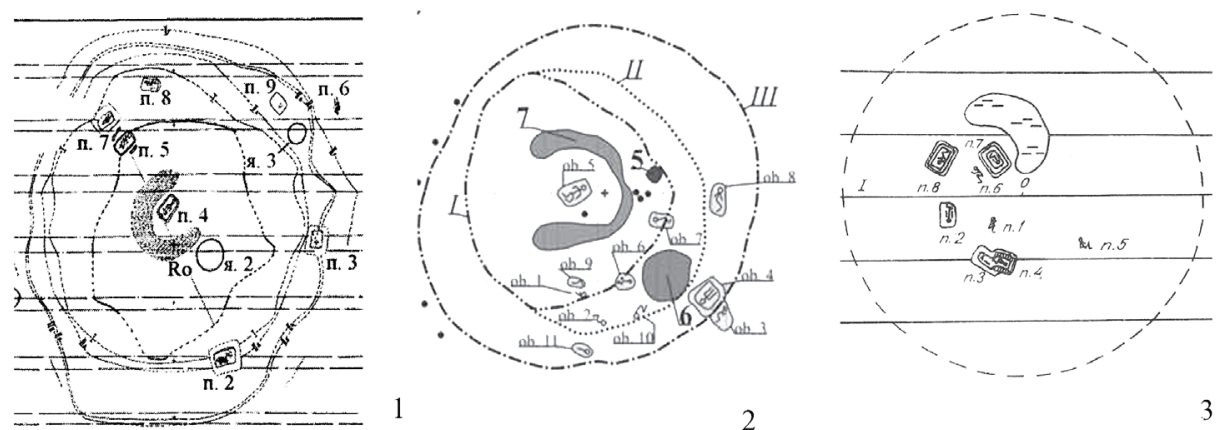

2
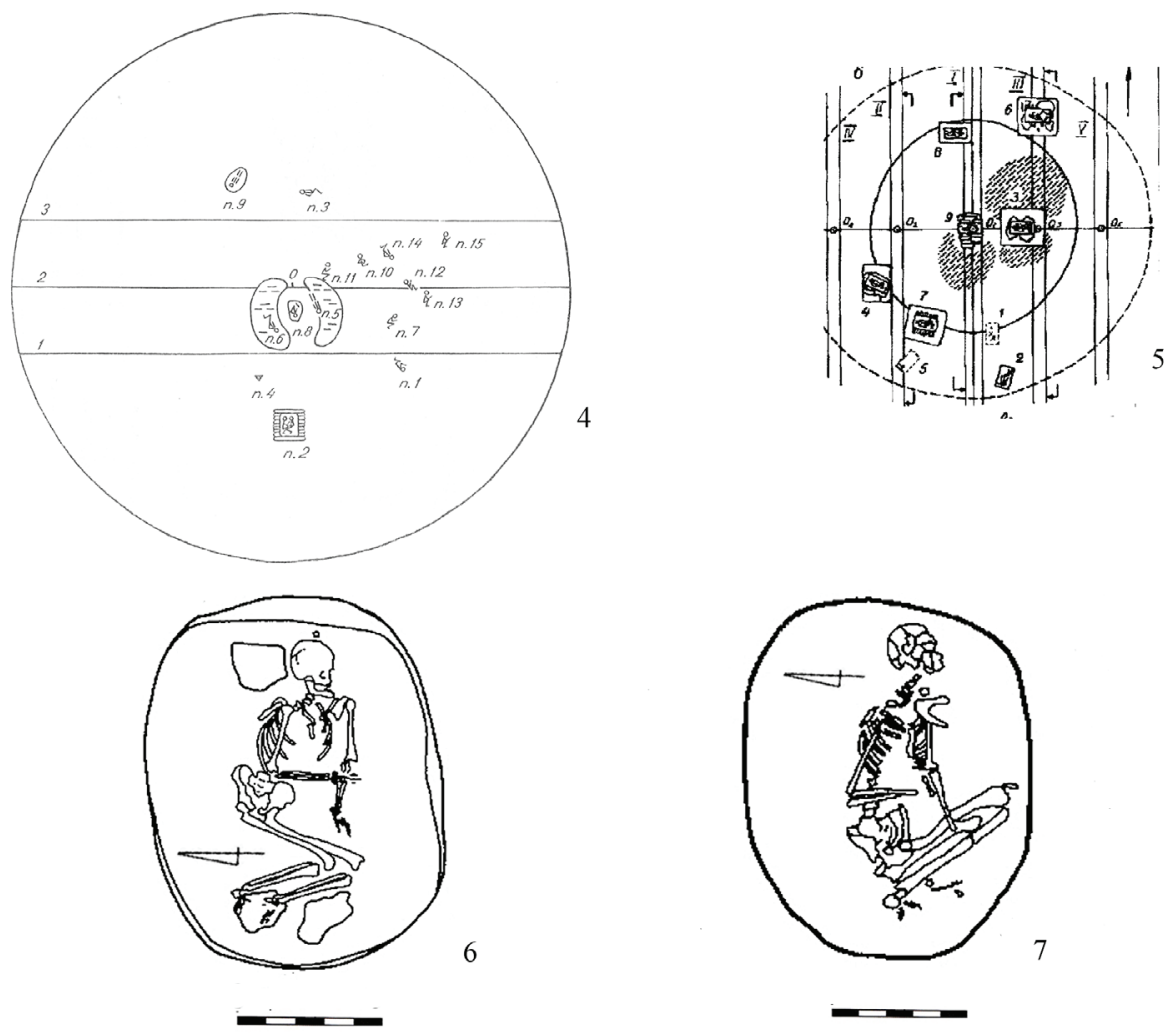

Fig. 29. Yamnaya culture barrows plans (1-5) and Eneolithic burial (6-7): contrast in "funerary architecture". The present (1-5) or its lack (6-7) the Inhumation site, of earth mounds from grave excavations (ukr. "wykid's") 1 - Brăviceni, barrow 2; 2 - Dobrianka, barrow 1; 3 - Olăneşti, barrow 8; 4 - Olăneşti, barrow 6; 5 - Belolesie, barrow 6; 6 - Sărăţeni 1/7; 7 - Trapovka 10/14 [after: 1 Larina et al. 2008; 2 - Harat et al. 2014; 3, 4 - Yarovoy 1990; 5 - Subbotin et al. 1998; 6 - Leviţki et al. 1996; 7 - Subbotin et al. 1995] 
and a flint arrow. Other finds included tooth pendants, a bone bead and a spiral gold pendant.

The distinguishing of the Yampil centre appears to be fully justified in the context of its characteristic traits and the marking out of the other regional centres. This can be seen in the distribution of pottery among the distinguished centres. 'Corded' amphorae are found in the Yampil and lower-Dniester Yasski-Mayaki centres, but they are absent from the Nicolscoe centre. There are finds from the Taraclia and Cazaclia sites located close to one another. One amphora was discovered in Ostrovnoe, near Kholmskoe [Ivanova et al. 2014: 359, Fig. 4.3. 3:3]. GAC amphorae are found mostly in the north, while in the south such finds are only sporadic (Novoselitsa 19/13, Tatarbunary 1/2). This distribution of pottery, related to the impact of the GAC and CWC, appears logical. However, beakers with a corded ornament were found only on the Yasski site and the nearby Beliaevka, Efimovka and Mirnoe barrows. Practically, they were recovered from various steppe zone barrows (Trapovka cemetery is one), while only one (Fig. 20:8) was found in the forest-steppe (Pererîta 2/1).

It is only natural that pottery reflecting links to the lower Danube cultures was more often discovered in the steppe zone of the Dniester-Danube interfluve.

'Budzhak pots' ('jars') and 'pot-like vessels' are connected mainly to the south of the steppe zone and the Dniester and Reut rivers (Fig. 28). There are cemeteries with the concentrations of this type of pottery (e.g. Semenovka, Novogradkovka, Plavni, Yasski with Efimovka close nearby), and others with single finds (Kholmskoe, Belolesie, Glubokoe). A similar situation is encountered in the case of small amphorae ('amphora-like vessels'). Several small amphorae were found on each of the following cemeteries: Olăneşti, Semenovka, Bolgrad, and Novokamenka, with single finds occurring as well. Examples of the latter in the forest-steppe zone include Mîndreşti 1/1, Mocra 1/3, Rogojeni 1/1 and 1/2.

Interestingly enough, the concentration of vessel finds of these two types is recorded in the lower Dniester drainage basin.

Perhaps, from the group of 'Yamnaya' burials of the Yampil centre, the Severynivka $1 / 5$ and Porohy $3 / 2$ burials should be excluded [Harat et al. 2014]. A number of traits make them closer to the Eneolithic burials of the north-western Black Sea Coast. This connection is indicated by the co-occurrence of the oval pit with the corpse lying on its side. Very similar in appearance no doubt, two Eneolithic graves are located in Sărăţeni 1/7 and Trapovka 10/14 (Fig. 29:6, 7). In addition, in the Trapovka grave, the undisturbed soil dug out from the grave pit was placed simply next to its edge [Subbotin et al. 1995: 66] as it is the case in the Severynivka 1/5 burial [Harat et al. 2014: 171, Fig. 2.15.4:5]. In 'Yamnaya' graves, soil excavated when digging a pit may have various shapes: that of a horseshoe or a bank and may surround the grave on one, two or three sides, sometimes occupying quite a large surface. Usually, the soil was placed some distance from the pit (Fig. 29:1-5). The variety found in the Severynivka $1 / 5$ grave is not characteristic of the YC. 


\section{THE CATACOMB CULTURE IN THE MIDDLE DNIESTER AREA}

In the area in question, $\mathrm{CC}$ sites are represented solely by burials. They make up 22 per cent of CC complexes known on the north-western Black Sea Coast. Settlements, as in the steppe zone, are not known.

In total, we know of over 30 barrows, containing more than $70 \mathrm{CC}$ burials. These are graves sunk into the barrow mounds of earlier cultures, mostly the YC. The barrows stand in groups or alone on high river banks, uplands or watersheds.

In one mound, there are from one to six grave assemblages (Codrul Nou, barrow 2). As a rule, they are concentrated in the southern portion of the mound. Usually, the entrance shaft was dug in the lower portion of the mound, with grave chambers pointing towards its centre. No case of imposition of one burial over another has been recorded, which suggests the use of grave markers.

Two grave groups can be distinguished, differing in their structure and skeleton arrangement. The first group comprises assemblages with a rectangular entrance shaft and crouched skeletons lying on their back (side). The other group is made up of graves with a circular entrance shaft and an oval grave chamber in which corpses lie extended on their back.

In relation to the adopted division, the burials may be considered as early (group 1) and late (group 2). In terms of number, late assemblages dominate. They were discovered on practically all sites under discussion.

A rather compact group of early burials was exposed in the Bezeda and Tețcani barrows, while single ones were recorded in other barrows, too (Fig. 30). Their characteristic trait is believed to be the covering of the entrance to the grave chamber with stone slabs.

The skeletons of adults and children usually lay crouched on their back, far less often on their left side. As a rule, these were single graves, only rarely double.

The orientation of the dead according to the points of the compass varies; generally, a southern orientation with some deviations dominates. The use of ochre, as shown by materials from the Teţcanii and Bezeda site, is very limited. On the bottom of grave chambers, rotten remains of padding are recorded, sometimes accompanied by charcoals.

Inventories comprise mostly pot-like vessels, only seldom are they decorated with cord impressions. A rare find is that of a small amphora, bearing a corded and incised ornament (Corjeuţi 4/10). Other finds include stone maces, arrowheads, animal tooth ornaments, a bronze awl, adze and beads. In a triple grave (burial 5), barrow 3 at Camenca-Ocniţa, a rare set was found, which included a fragment of a bronze bracelet and knife with a sharp-ending handle. Rather rare on the scale of the entire north-western Black Sea Coast, this find is strongly believed by the authors of the original publication to be analogous to the goods from Bakhmut sites in eastern Ukraine [Manzura et al. 1992: 92]. 


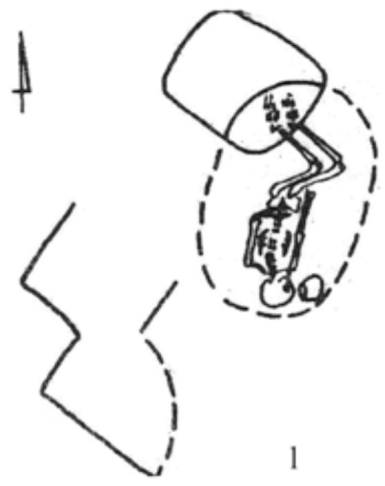

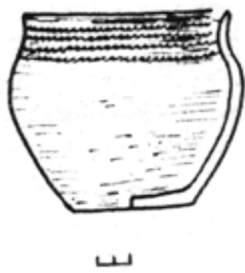

2

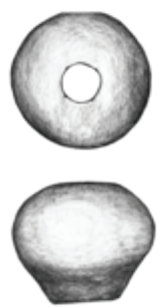

$0-{ }^{3}$

5

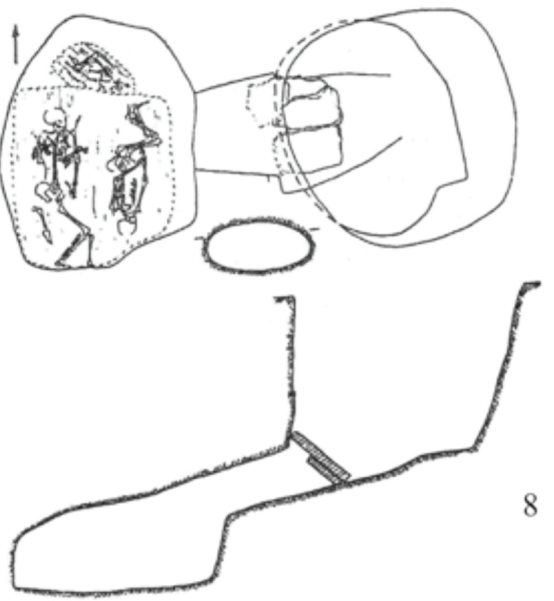

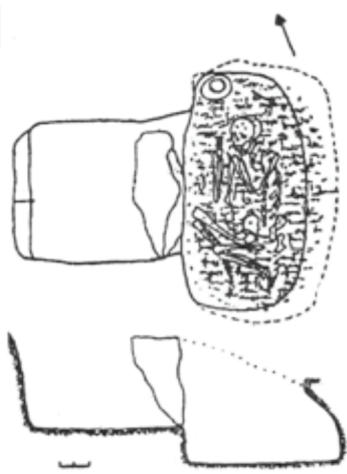

3

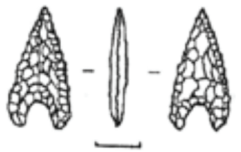

6

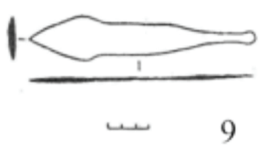

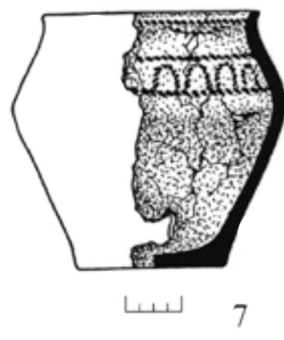

Fig. 30 . Catacomb culture graves assemblages from 'early sites'

1-2 - Medveja 4/6; 3-4 - Corjeuţi 4/10; 5 - Prydnistryanske 1/4; 6 - Cuzmin 2,5; 7 - Duruitoarea Nouă 3/2; 8-9 - Ocniţa 3,5 [after: 1-2 -Savva, Dergachev 1984; 3-4 - Leviţki, Demcenko 1994; 5 Włodarczak et al. 2015; 6 - Bubulich, Khakheu 2002; 7 - Demchenko 2007; 8-9 - Manzura et al. 1992] 

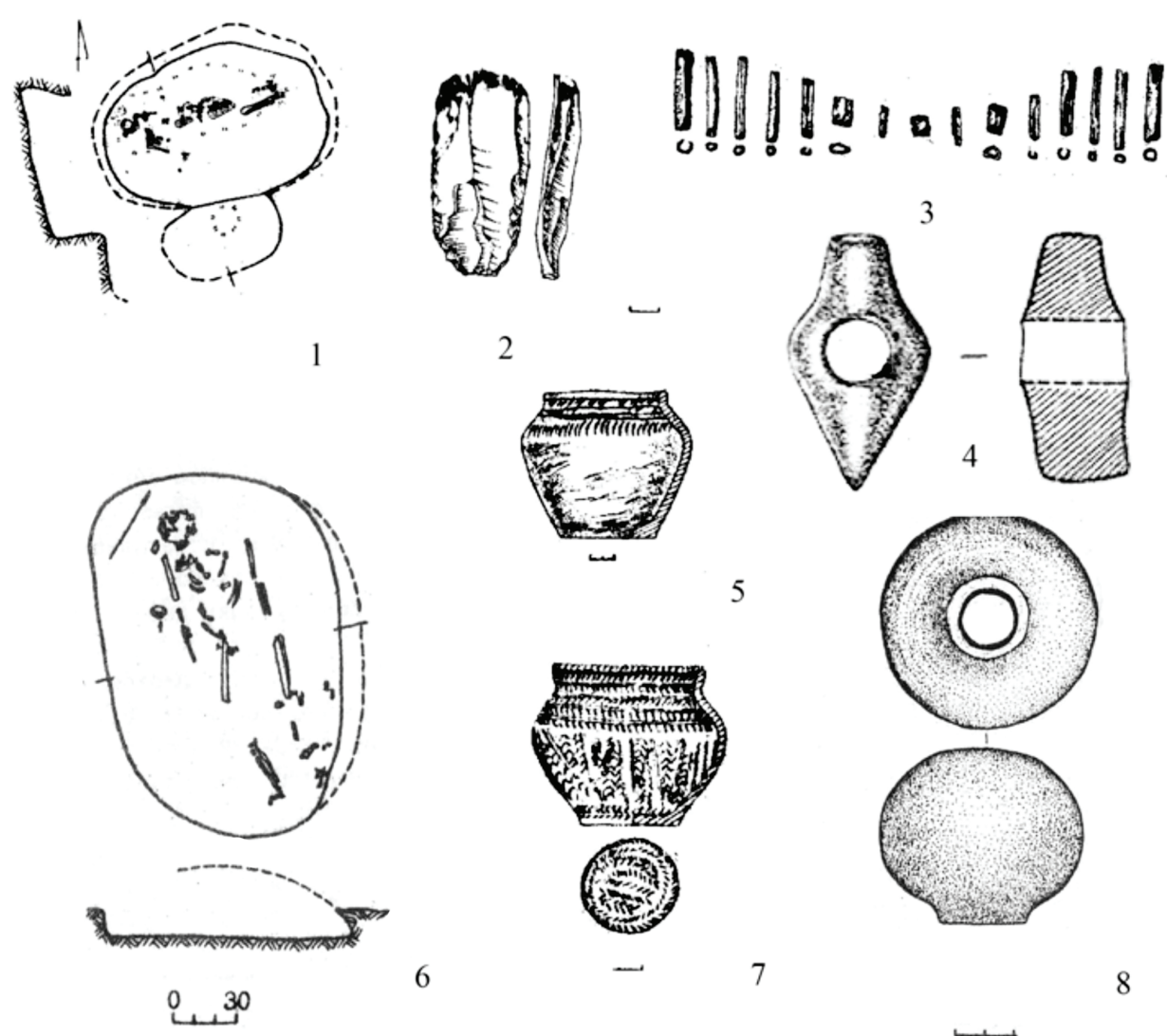

6

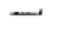

7

Fig. 31. Late Catacomb culture materials, burial plan maps and grave goods

1-3 - Dumeni 1/9; 4, 4 - Cotiujeni 1/1; 5 - Dumeni 1/4; 7 - Duruitoarea Nouă 1/4; 6,8 - Corpaci 3/7 [after: 1-3, 5 - Dergachev 1986; 4 - Agulnikov 1992; 7 - Demchenko 1988; 6,8 - Yarovoy 1984]

In terms of all markers (structure, corpse position, inventory), the group of catacombs discussed above corresponds to features encountered in the south, in the steppe zone.

The burials of group 2 are more numerous (up to 70\%). They are found in barrow mounds together with earlier ones or they make up separate cemeteries. Individual graves dominate with supine extended skeletons. Collective burial 2, barrow 2, Codrul Nou, held four skeletons. In this case, a rare custom of adding the dead to a grave was encountered, with the bones of those buried earlier being moved aside. In grave 4, barrow 3, of the same site, the bones of the deceased were placed as a 'package'.

Grave inventories are dominated by pottery, with stone goods being rare: a mace (Corpaci 3/7) and shaft-hole axes (Cotiujeni 1/1). In the Hancăuţi 1,8 bur- 
ial, next to the skeleton, three hollow-base points were found. Other flint goods were represented by a knife (Dumeni 1/9). Bronze goods are very rare. A set of beads was discovered in grave 9, barrow 1 , on the Dumeni site. Cenotaphs are also known (Duruitoarea Nouă 2/5; Dumeni 3/4).

'Catacomb' materials from the forest-steppe zone are fully consistent with better-known materials from the Dniester-Prut interfluve steppe. This is only natural as the protracted conquest of territories lying further north originated in the south and southeast, with the Prut drainage basin being conquered more intensively. It was there in fact that a site concentration was recorded on the left bank of the Prut. On the other hand, isolated sites in Romanian Moldavia testify to single cases of penetration of the right bank [Burtănescu 2002]. A similar situation can be observed further south, in the steppe zone.

In the forest-steppe portion of the Dniester drainage basin, the situation is different. However, the presence of only single CC assemblages may be explained by the small range of excavations.

So far, the north-westernmost point of the CC area is the site of Święte in the upper Vistula drainage basin on which the traits of both YC and $\mathrm{CC}$ have been recorded [Kośko et al. 2012].

Generally speaking, it must be observed that in CC grave assemblages, in the forest-steppe portion of the Dniester-Prut interfluve, both early (corner entrance shafts, corpse arrangement) and late (oval grave chambers, grave goods) traits occur (Fig. 31). This trait co-occurrence can be explained by the prolonged settlement of the area by CC communities.

Further, the find of a $\mathrm{CC}$ vessel in a YC burial apparently testifies to the co-occurrence of the $\mathrm{YC}$ and $\mathrm{CC}$ in this zone (burial 2, barrow 1, Pererîtaw, Briceni district) [Kurchatov 2006: 285]. Similar cases were recorded on steppe zone sites [Toschev 2013]. In general, they bear out the conclusions of researchers about the co-existence of the late $\mathrm{YC}$ and $\mathrm{CC}$ in a specific period.

A small series of ${ }^{14} \mathrm{C}$ dates for the $\mathrm{CC}$ in the north-western Black Sea Coast fits into the interval of 2580-2341 to 2267-1981 BC [Ivanova et al. 2012]. Relying on materials from the Dniester-Prut interfluve, E. Kaiser [2003] dated CC sites to the interval of 2450-1950 BC.

Directly for the area under discussion, ${ }^{14} \mathrm{C}$ dates were obtained for a single assemblage: Prydnistryanske 1/I-4 [Goslar et al. 2015], found in a barrow forming part of the Dniester Barrow Site Group. This assemblage is the only to be recorded among those discovered in this group (four Late Eneolithic and Early Bronze mounds were excavated) and among all Yampil barrows as well ${ }^{16}$.

The 'catacomb' burial with two skeletons which was excavated on the Prydnistryanske site was furnished with a mace head. It has analogies in 'catacomb'

16 Most sites were excavated in the 1980s; it cannot be ruled out that peculiar catacomb assemblages located on mound edges were not noticed at that time [Harat et al. 2014]. 
burials from various stages [Klochko 2006: 105, Figs. 37, 45]. Corpse arrangement (crouched on their back and leaning sideways) provides grounds to assign this burial to the final portion of the early 'catacomb period'. This conclusion is not contradicted either by four dates obtained for bones (3) and wood (1): 2726-2493; 2633-2495; 2566-2406; 2565-2406 BC (68.2\%) [Goslar et al. 2015], which generally fit into the brackets set by the dates mentioned earlier.

The forest-steppe materials known so far do not supply any data on direct contacts between the CC and the Central European CWC [Włodarczak 2006; Toschev 2013].

\section{THE BABYNO CULTURE IN THE MIDDLE DNIESTER AREA}

The overall number of studied funerary features associated with the BC amounts to 60. Most of the time they are discovered in barrows situated on the forest-steppe of the Dniester and Prut drainage basins. There are no data on any settlements.

There is no clear rule of attributing a larger series of assemblages to the BC. The problem of the cultural attribution of barrow burials with skeletons crouched on their side and deprived of any grave goods was raised by V.A. Dergachev [1986: 122-126, 175]. In spite of the lapse of several decades, the question remains open. Some researchers attribute such assemblages to the BC [Lytvynenko 2009], while others refer those which are located on the steppe to the Sabatinovka culture [Savva 1992; Sava, Agulnikov 2003].

Later on, in the forest-steppe zone, barrow burials linked to the Komarov (Corpaci, Medveja) and Noua (Corjeuţi, Burlăneşti) cultures appeared, while further south, in the Dniester-Prut interfluve, there extended the domain of 'Sabatinovka' tribes [Dergachev 2010: 296-305].

It should not come as a surprise that in most cases a peculiar material served as a marker for determining the cultural attribution of a funerary assemblage. The absence therefore of grave goods leads to various conclusions. In a number of cases, the presence of a vessel having a pot- or jar-like form next to a crouched skeleton is not a precise marker [Savva 1992: 115]. Frequently, the pit structure cannot be discerned, sometimes, skeletons are damaged and only the inventory (usually a buckle) helps to determine the cultural attribution. For this reason, numerical data given by various authors always differ. In the zone under discussion, 


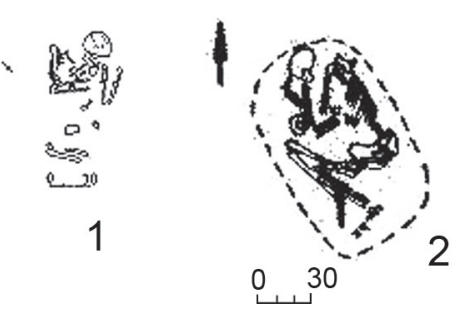

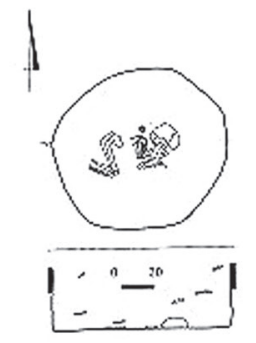

3

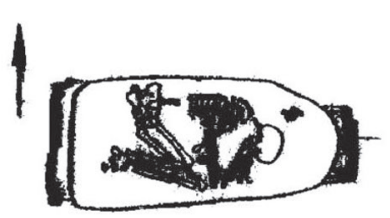

解 תIT
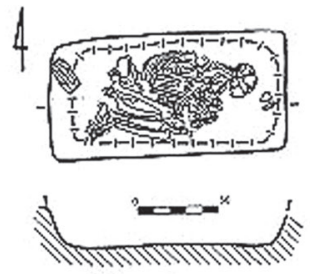

4

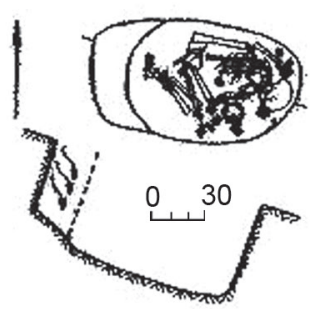

5
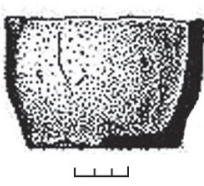

8

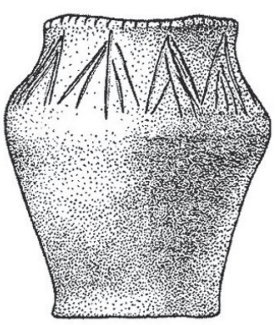

13

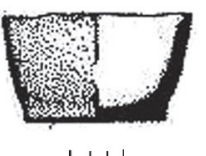

9

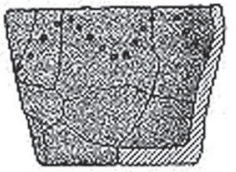

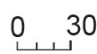

6
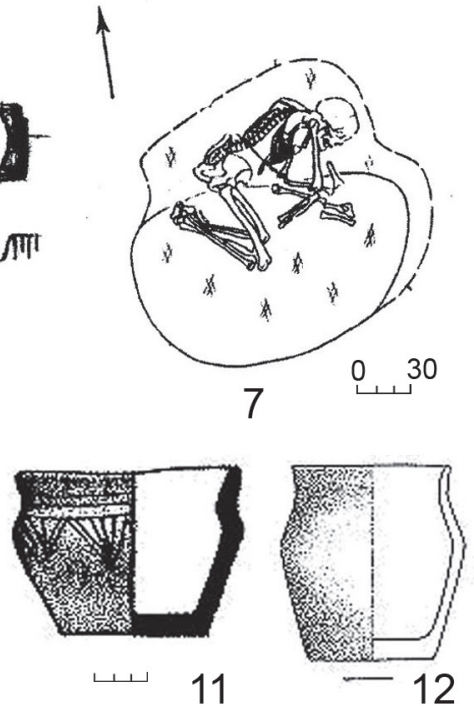

10
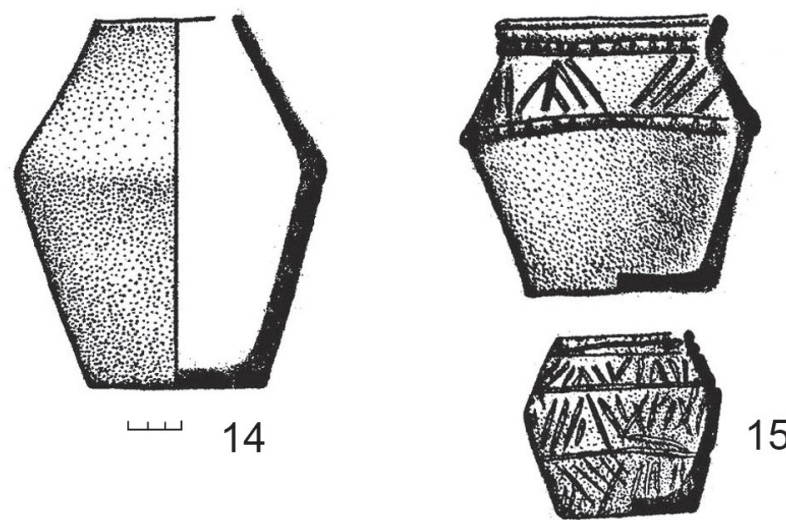

Fig. 32(A). Babyno culture funerary assemblages in the Dniester-Prut basins. 1, 19 - Brăviceni 15/1; 2, 9, 26 - Ocniţa 6/7; 3, 22, 23 - Severynivka 1/4; 4, 17 - Porohy 3A/5; 5, 11, 24, 25, 27 Ocniţa 7/13; 6, 8 - Ocniţa 3/2; 7, 10 - Porohy 4/1; 12, 21 - Brăviceni 7/7; 13, 20 - Brăviceni 15/2; 14 - Cotujeni 3/1; 15 - Cuconeşti Vechi 9/31; 16 - Klembivka 1/11; 18 - Ocniţa 2/2; 28 - Brăviceni 3/2; 29 - Dobrianka 1/3; 30 - Cuconeşti Vechi 9/28 

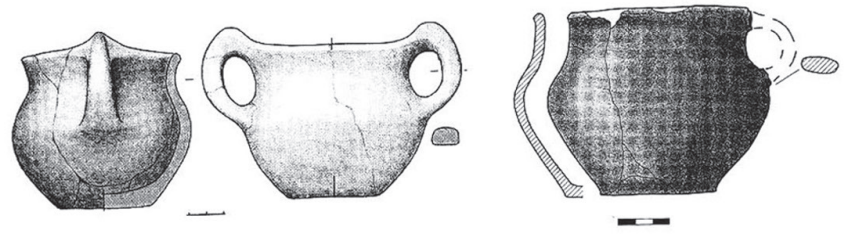

16
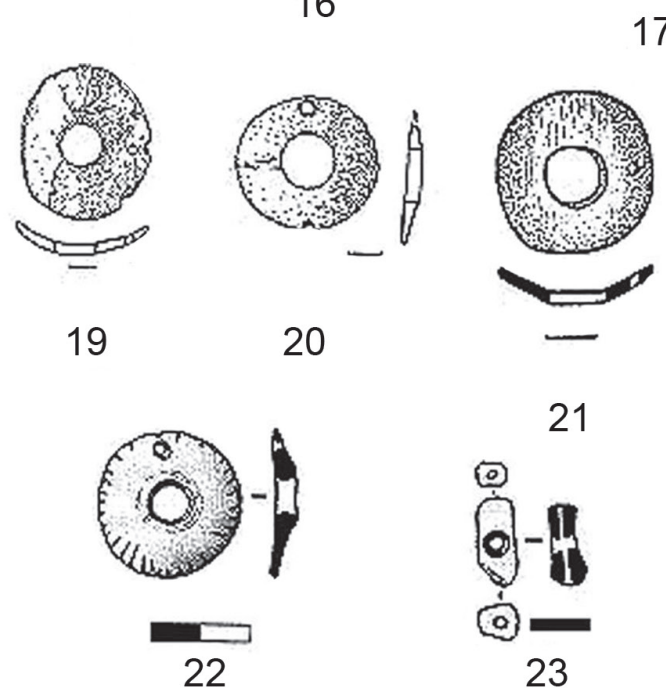

20
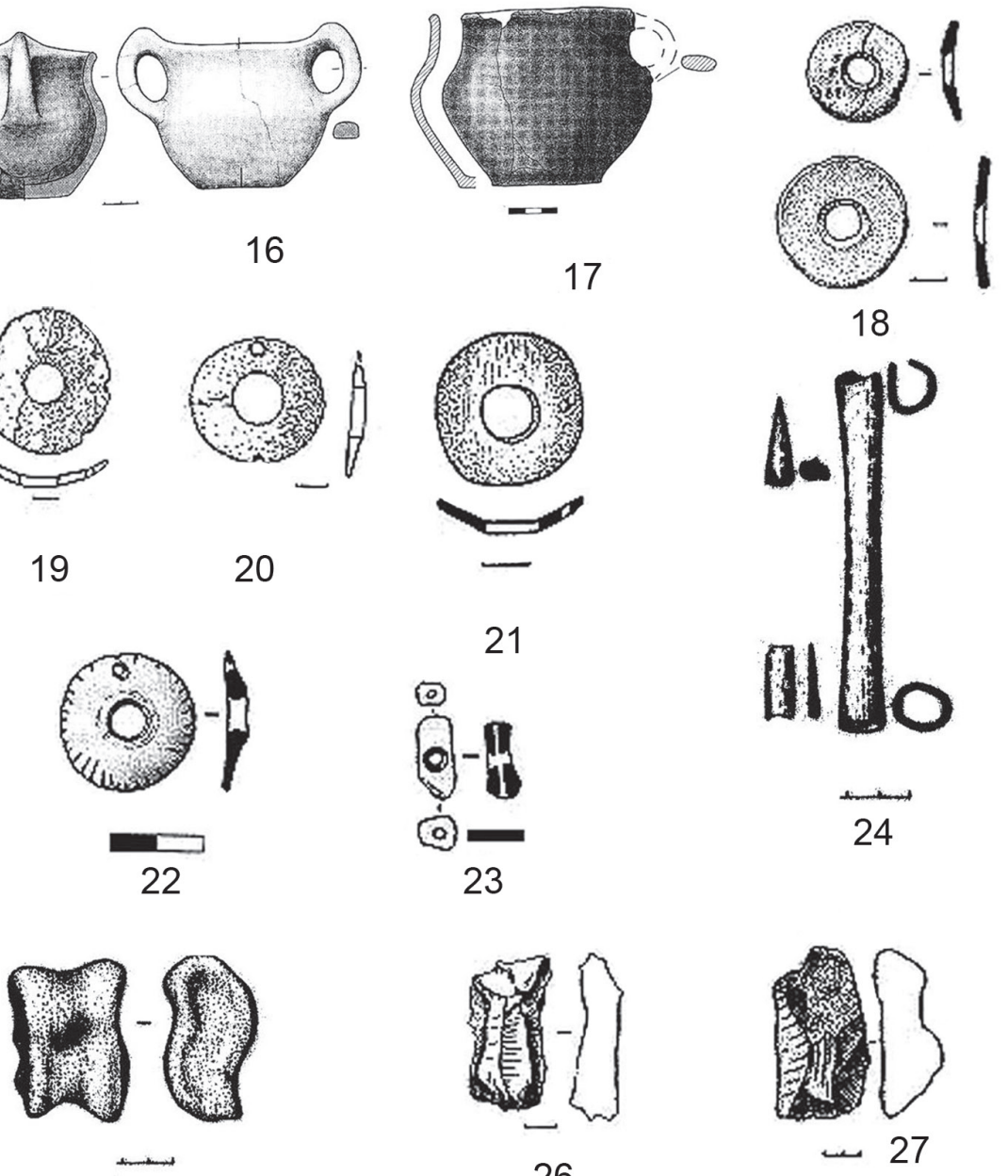

18
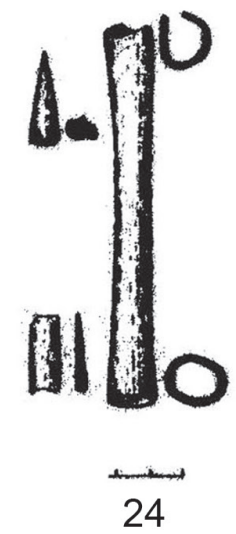

25
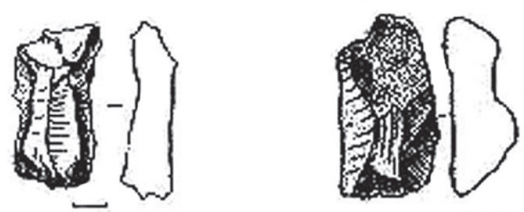

26
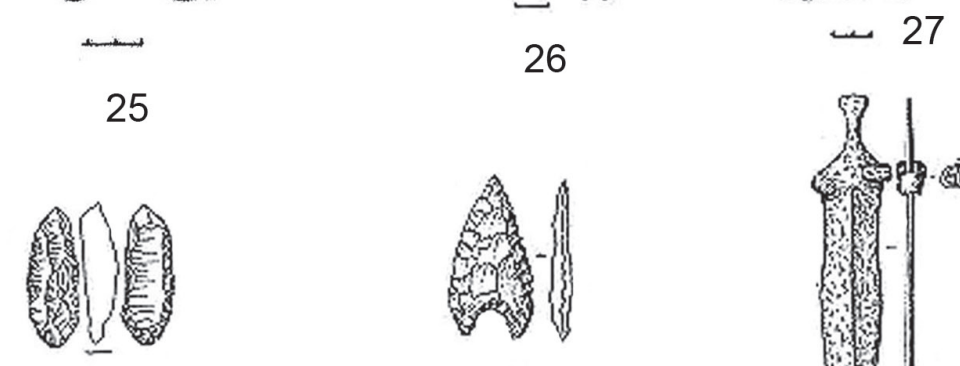

28
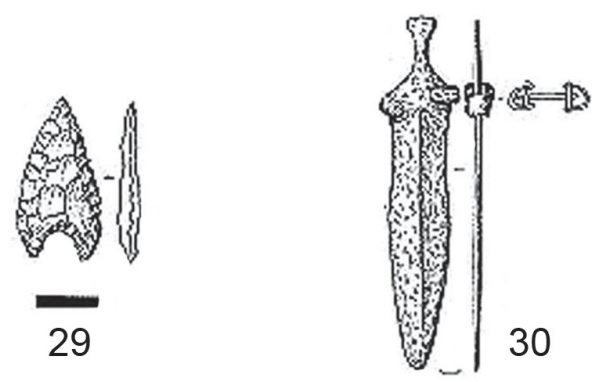

Fig. 32 (B). Babyno culture funerary assemblages in the Dniester-Prut basins. [after: 1,19Larina et al. 2008; 2,9,26 - Manzura et al. 1992; 3,22,23 - Harat et al. 2014; 4,17 - Harat et al. 2014; 5,11,24,25,27 - Manzura et al. 1992; 6,8 - Manzura et al. 1992; 7,10,29 - Harat et al. 2014; 12,21 - Larina et al. 2008; 13,20 - Larina et al. 2008; 14 - Agulnikov 1992; 15 - Dergachev 1986; 16 - Razumov et al., 2013; 18 - Manzura et al. 1992; 28 - Larina et al. 2008; 30 - Dergachev 1986] 
$\mathrm{BC}$ burials were sunk into barrows built earlier by $\mathrm{YC}$ representatives ${ }^{17}$. In the mound, as a rule, they are concentrated in its southern portion. In single cases, they are arranged to form an arch and in barrow 15 in the Brăviceni site, they were situated in the mound centre.

Credible observations of grave structure are available for 30 per cent of features. Simple structures dominate: oval or rectangular pits. Graves with a wooden structure (Severynivka 2/2; Ocniţa 3/2), stone cist (Ocniţa 3/7) or a niche (Dobrianka 1/3, Brăviceni 3/2) are single occurrences (Fig. 32: 1-7). They are found in mounds together with graves of different structures.

Skeletons were usually placed in the crouched position on their left side (less often on the right), sometimes twisted with the chest facing down, with their hands variously arranged; occasionally both hands were raised to the face. An eastern orientation with deviations dominates.

Grave goods comprise pottery and bone buckles, with a single or double perforation, characteristic of this culture, and flints. The set of pottery is rather meagre; these are chiefly pot- or jar-like vessels in different varieties and pot-like vessels, with biconical ones being rare (Fig. 32: 13-15). Usually, a burial contained a single vessel, but in Porohy 4/1 there were two. In the Cuconeşti Vechi 9/32 burial, a discovery was made of two vessels richly ornamented with coils and incised lines. Incised lines, too, forming a pattern of triangles decorated vessels from Brăviceni 15/2 and Ocniţa 7/13.

Very rich grave goods were recovered from burial 13, barrow 7, the Ocniţa site. They included an ornamented vessel and bone and flint goods [Manzura et al. 1992].

A rather popular category of finds is made up of bone buckles. Next to a skeleton, there usually lay one buckle (Duruitoarea Nouă 3/1; Brăviceni 7/1;7/7; $15 / 1 ; 15 / 2 ; 16 / 2$; Cuconeşti Vechi $4 / 2$; Văratic $1 / 5)$, only in one feature were two discovered (Ocniţa 2/2). One buckle was ornamented (Severynivka 1/4); this feature yielded also a deer-tooth fibula with oblique perforations (Fig. 32: 23). The last-mentioned find is unique as it helps give a clearer answer to the question about the purpose of such objects as fastenings (fibulae). The buckles lay next to the deceased (man, woman or child) in various places.

The buckles belong to several different types according to E.N. Savva: round with a single perforation (type I), round with two perforations (type II) and single 'others' with an edge and perforation (Fig. 32: 18-21). Type I is interpreted as being earlier [Savva 1992: 131-133].

Among bone goods, let us also mention here a rather rare object in the assemblages of this culture, namely a case with a perforator (perforation?) inside

17 The authors of Kurhany Brăviceni interpret burial 2, barrow 16, as 'Babyno' and connect it to the adding of more earth to the barrow. In this case, it seems plausible to treat this feature as 'late Yamnaya'. It forms a referential arch with burials 6, 8 and 9, which is typical of this period [Larina et al. 2008: 77]. The cases of placing corpses on their left/right side were recorded many times in late YC burials. 
- Ocniţa 7/13 (Fig. 32: 24). The same burial contained a whole set of astragals: 21 specimens, with some of them bearing traces of working (Fig. 32: 25).

A rare find in both this region and the entire $\mathrm{BC}$ area is believed to be a tanged knife-dagger with a long ribbed blade and a narrowing (Fig. 32: 30) from burial 28, barrow 9 in Cuconeşti Vechi (1974 excavations). In this grave, the skeleton lay on its left side, with the head directed towards NNE and the hands placed close to the chest. The range of analogies for this object is very broad and the opinions of researchers are varied [Lytvynenko 2006: 42, 46].

In one of the burials (Dobrianka 1/3), amid the bones of the deceased, a Babyno-type arrow point was found (Fig. 32: 29). S.M. Razumov cites information about five other similar finds of points, which were seen to have inflicted injuries, from four graves [Razumov 2014: 350].

Flints as grave goods were found in a number of burials; they are represented by flakes and blades, and a fabricator - Ocniţa 6/7; Ocniţa 7/13; Brăviceni 3/2 (Fig. 32: 26-28). There are also cases of the occurrence of animal bones in burials (Pidlisivka 1/5, 1/7; Ocniţa 3/2; 7/13; Brăviceni 3/2, Porohy 3A/5). In addition, small amounts of ochre were recorded in single burials; there are also single instances of finding charcoals (Brăviceni 7/7).

$\mathrm{BC}$ materials from the area under discussion (funerary rite, grave goods) are fully consistent with those originating from the areas located further south, in the steppe-zone. They support the belief that it took $\mathrm{BC}$ representatives a long time to settle these territories.

One ought to notice characteristic traits as well: absence of central burials, additions of earth to barrows or pits with a step. This series of observations (about 20 features) comes from the steppe zone stretching between the Danube and Dniester. Furthermore, grave goods appear more meagre; they are made up for the most part of rather uncharacteristic pottery, bone buckles, rare flints and a single bronze object. Among the grave goods of the latter no objects originating with other cultures have been recorded (a possible exception might be the knife from Cuconeşti Vechi), which may testify to the certain isolation of $\mathrm{BC}$ communities in this region.

It must be also noted that on the strength of two vessels - bowls with one or two handles (Fig. 32: 16-17) - found in burials included in the Babyno cultural circle (Klembivka 1/11 and Porohy 3A/5), researchers arrived at a conclusion about "the overlapping of the Babyno and Trzciniec (Komarov) cultural circles" [Lysenko, Razumov 2014: 14, 19]. While in BC materials in the southern zone (Olăneşti $1 / 22$ ) one can certainly speak of Komarov imports, similar 'bowls' with one or two handles are very common among various cultures of the Carpathian-Danubian Basin towards the end of the Middle and in Late Bronze Age. This fact is described in sufficient detail also by the researchers quoted above.

Let us note, too, that from among Late Bronze Age burials exposed in a barrow on the Klembivka site, five were classified as BC, while another five were attrib- 
uted to the Sabatinovka culture [Razumov et al. 2013; for a different approach see Klochko et al. 2015b].

In respect of Porohy 3A/5, S. Lysenko and S. Razumov [2014: 15] give a radiocarbon date obtained for human bones in the Kyiv laboratory: Ki-17440: $3200 \pm 90$ $\mathrm{BP}=1 \delta-1610-1550,1540-1380,1340-1320 ; 2 \delta-1690-1250 \mathrm{BC}$. This time determination is very broad and covers the lifespan of various cultures. Hence, it is more reasonable to consider most assemblages from the Klembivka barrow within the general bracket of the Late Bronze Age.

The sites in the Dniester-Prut interfluve were dated by E.N. Savva [1992: 178] to the period from the 17 th to the turn of the 15 th century BC, while I. Pâslaru [2006: 168-169] referred the Delacău-Babyno culture to the 17th-15th century BC. In the light of new chronological analyses, R.A. Lytvynenko [2009: 26], in turn, believes it to be possible to date all Babyno circle sites to the 2200-1800 BC bracket. The question of the dating of $\mathrm{BC}$ sites in the Dniester-Prut interfluve remains open, arguably, as it is necessary to obtain a series of new radiocarbon measurements from features of undisputable cultural attribution.

We also know of BC sites lying further northwest, in Lviv, Rivne and Tarnopil oblasts. They include both settlement and funerary assemblages, sometimes lying together with Strzyżów and sub-Carpathian CWC materials. As to a degree contemporaneous with the $\mathrm{BC}$ on the Volhynia and western Podolia forest-steppe, one can consider the following cultures: Strzyżów, Sub-Carpathian and late GródekZdołbice [Sveshnikov 1990: 74-77; Bandrivskyi 1997; 2006; Okhrimenko et al. 2012; Lytvynenko 2009]. The investigations in this region produced both single funerary complexes (Ostapie, Palikorovo, Zhorniv) and the finds of pottery and bone buckles within settlements, in the latter case, not infrequently together with the materials of other cultures (Svitiazev, Pereveredovo, Zvenigorod). For a long time, they were used to synchronize the BC with local cultures [Sveshnikov 1990; Berezanskaya 1986; Toschev 1987]. They also show that single 'Babyno' population groups penetrated the upper Dniester drainage basin, that is territories settled by neighbouring tribes [Lytvynenko 2009: 12]. Admittedly, another opinion holds that the upper Dniester drainage basin should be incorporated into the $\mathrm{BC}$ area [Pâslaru 2006: 233]. However, insufficient exploration of the area in question prevents us, for the time being, from drawing unequivocal conclusions.

***

The purpose of the study of the middle Dniester (or sometimes, in broader approaches, north-western Pontic) area of 'barrow cultures' from the Late Eneolithic and the prologue of the Bronze Age (4th/3rd-2nd millennium BC) was to conduct an analytical and conceptual entry point to the questions of contacts, considered in terms of taxonomy and autogenesis, subsisting between local communities of the 'Late Eneolithic', YC, CC and BC and incoming, neighbouring communities from the Baltic basin and traceable mainly to the Vistula and Oder drainage basins (chiefly the GAC and CWC). 
The proposals advanced in the text concerning the correspondence of civilization experiences of both community groups, settling the north-western Black Sea Coast and the Baltic basin, should be treated as an important voice in the necessary discussion that is continued in this volume of Baltic-Pontic Studies in the next paper. It puts a 'central European' perspective on the Dniester Contact Area of interest to us here [Ivanova et al. 2015].

Translated by Piotr T. Żebrowski 


\section{REFERENCES}

Abyzova E.N., Klochko E.O.

2003-2004 Kurgannyi mogilnik u s. Kirileny. Stratum Plus 2: 266-319.

Agulnikov S.M.

1992 Issledovanie kurganov u s. Kotiuzhen. In: Archeologicheskie issledovaniya v Moldavii (1986 g.), 104-120. Kishinev.

1995 Imporrturi de pe cursul inferior al Dunării în complexele arheologice ale bronzului timpuriu din stepa Bugeacului. Cercetarii arheologice in aria Nord-Traca, V-I: 81-86.

2008 Arkheologicheskoe nasledie Budzhaka. Revista de Etnologie ši Culturologie 3: 227-244.

Agulnikov S., Mistreanu E.

2014 Novye nakhodki kamennykh orudiy na pamiatnikakh pozdnego bronzovogo veka stepnoy zony Moldovy. Revista Arheologică serie nouă 9(1-2): 203-209.

Agulnikov S., Mistreanu E., Popovici S.

2014 Cercetări de salvare la tumulul de la Rogojeni, r-nul Şoldăneşti. Arheologia Preventivă în Republica Moldova 1(1-2): 35-42.

Agulnikov S., Popovich S.

2010 Obriad demembratsii v yamnoy kulture Pruto-Dnestrovskogo mezhdurechia. In: Problemy okhrany i izucheniya pamiatnikov arkheologii stepnoy zony Vostochnoy Evropy. Sbornik statey, 323-344. Lugansk.

Alaiba R.

2004 Ceramica de tip Cucuteni C. In: M. Petrescu-Dîmboviţa, M.C. Văleanu (Eds) Cucuteni-Cetăţuie. Săpăturile din anii 1961-1966. Monografie arheologică, 229-243. Piatra-Neamţ.

Alaiba R., Grădinaru I.

1999 Cercetări arheologice din anii 1995-1996 de la Cărniceni Pe-Coastă jud. Iaşi, Cercetări arheologice în aria nord-tracă 3: 7-15.

Alekseeva I.L.

1992 Kurgany epokhi palleometalla $v$ Severo-Zapadnom Prichernomore. Kyiv.

Alexandrescu A.D.

1974 La nécropole du bronze ancien de Zimnicea [dép. de Teleorman]. Dacia 18: 79-93. 
Andrukh S.I., Dobroliubskiy A.O., Toschev G.N.

1985 Kurgany u s. Plavni v nizoviakh Dunaya. Moskva (held in the INION AN SSSR 13.06.85, No 21110).

Bandrivskiy M.S.

1997 Vidkrittia pamiatok kultury bahatovalikovoyi keramiki na Lvivschyni. Arkheologiya 1: 138-142.

2006 Pivnichno-zakhidna periferiya kulturnoho kola Babyno: sposterezhennia za khronolohieyu ta pokhovalnym obriadom. In: Istoriya relihiy $v$ Ukrayini. Naukovyi schorichnyk, vol. I, 8-21. Lviv.

Berciu D., Morintz S., Roman P.

1973 Cultura Cernavoda II. Aşezarea din sectorul b de la Cernavoda. Studii şi cercetări de istorie veche (şi arheologie) 24(3): 373-405

Berezanskaya S.S.

1986 Kultura mnogovalikovoy keramiki. In: S.S. Berezanskaya, V.V. Otroschenko, N.N. Cherednichenko, I.N. Sharafutdinova (Eds) Kultury epokhi bronzy na territorii Ukrainy, 5-43. Kyiv.

Beylekchi V.S.

1992 Raskopki kurgana 3 u s. Mierkulesht. In: Archeologicheskie issledovaniya v Moldavii (1986g.), 72-87. Kishinev.

Bikbaev V.M.

1994 Predgordineshtskie pamiatniki tipa Kirilen v Severnoy Moldove. In: E.V. Yarovoy (Ed.) Drenevneyshie obschnosti zemledeltsev $i$ skotovodov Severnogo Prichernomoria V tys. do n.e. - V v. n.e., 64-69. Tiraspol.

Bubulich V., Khakheu V.

2002 Issledovanie kurganov v Kamenskom rayone na levoberezhe Srednego Dnestra. In: N.A. Ketraru (Ed.) Severnoe Prichernomorie: ot eneolita $k$ antichnosti, 112-148. Tiraspol.

Burdo N.

2004 Tsviklovetskyi skarb. In: M.Y. Videyko (Ed.) Entsyklopediya trypilskoyi tsyvilizatsiyi, vol. II, 587-588. Kyiv.

Burtănescu F.

2002 Epoca timpurie a bronzului între Carpaţi şi Prut cu unele contribuţii la problemele perioadei premergâtoare epocii bronzului in Moldova. Bucureşti. 
Chebotarenko G.F., Cherniakov I.T., Toschev G.N.

1993 Kurgany u s. Primorskoe. Drevnosti Stepnogo Prichernomoria i Kryma 4: 46-61

Cherniakov I.T.

1979 Kulturno-khronologicheskie svoeobrazie pamiatnikov epokhi bronzy Severo-Zapadnogo Prichernomoria. In: Problemy epokhi bronzy yuga Vostochnoy Evropy: Tezisy dokladov konferentsii 3-6 dekabria 1979 g., 8-10. Donetsk.

Chirica V., Tanasachi M.

1985 Repertoriul arheologic al județulul Iaşi, vol. I-II. Iaşi.

Demchenko T.A.

1988 Issledovaniya kurganov v Ryshkanskom rayone. In: Archeologicheskie issledovaniya $v$ Moldavii (1988g.). Kishinev.

2007 Arheologicheskie issledovaniya kurganov levoberezhia Srednego Pruta (raskopki 1982 i 1984 gg.). Tyragetia. Serie nouă 1(XVI): 195-215.

Demchenko T.I, Levitskiy O.G.

2006 Kurgany u sela Burlienesht. Revista Arheologică. Serie nouă 2 (1-2): 293$-327$.

Dergachev V.A. (=Dergaciov V.)

1973 Pamiatniki epokhi bronzy. Arheologicheskaya karta Moldavii, vol. 3. Kishinev.

1980 Pamiatniki pozdnego Tripolia. Kishinev.

1982 Materialy raskopok arkheologicheskoy ekspeditsii na Srednem Prute (1975-1976 gg.). Kishinev.

1986 Moldaviya i sosednie territorii v epokhu bronzy. Kishinev.

2010 Evoluţia comunităților patriarhale. Epoca bronzului. In: V. Dergaciov et al. (Eds) Istoria Moldovei. Epoca preistoricăși antică: (până în sec. V), 265-311. Chişinău.

Dergachev V.A., Manzura I.V.

1991 Pogrebalnye kompleksy pozdnego Tripolia. Kishinev.

Dresely V., Müller J.

2001 Die absolutchronologische Datierung der Schnurkeramikim Tauber-undim Mittelelbe-Saale-Gebiet. In: J. Czebreszuk, J. Müller (Eds) The Absolute Chronology in Central Europe 3000-2000 BC. Poznań-Bamberg-Rahden/Westf. 
Dumitroaia Gh.

2000 Comunităţi preistorice din nord-estul României. De la cultura Cucuteni până în bronzul mijlociu. Bibliotheca Memoriae Antiquitatis, vol. 7. Piatra-Neamţ.

Gey A.N.

2011 Spornye voprosy i perspektivy izucheniya katakombnoy kulturno-istoricheskoy obschnosti. Kratkie soobscheniya Instituta arkheologii 225: 3-15.

Goslar T., Klochko V.I., Kośko A., Włodarczak P., Żurkiewicz D.

2015 Chronometry of Late Eneolithic and 'Early Bronze' cultures in the Middle Dniester area: investigations of the Yampil Barrow Complex. In: A. Kośko (Ed.) Podolia as a Cultural Contact Area in the 4th/3rd-2nd Millennium BC. Baltic-Pontic Studies 20: 256-291.

Harat K., Potupczyk M., Razumow S.

2014 Charakterystyka źródeł archeologicznych pozyskanych w latach 1984-1993. In: A. Kośko, M. Potupczyk, S. Razumow (Eds) Naddniestrzańskie kompleksy cmentarzysk kurhanowych społeczności z III $i$ z pierwszej połowy II tysiaclecia przed Chr. w okolicach Jampola, obwód winnicki. Archaeologia Bimaris - Monografie 6, 45-204. Poznań.

Ivanova S.V.

2001 Sotsialnaya struktura naseleniya yamnoy kultury Severo-Zapadnogo Prichenpmoria. Odessa.

2009 Istoricheskie protsessy v Yugo-Vostochnoy Evrope (eneolit-ranniy bronzovyi vek). In: Problemy izucheniya kultur bronzovogo veka stepnoy zony Vostochnoy Evropy, 49-58. Orenburg.

2013 Connections between the Budzhak Culture and Central European Groups of the Corded Ware Culture. In: A. Kośko (Ed.) The Ingul-Donets Early Bronze Age Civilization as Springboard for Transmission of Pontic Cultural Patterns to the Baltic Drainage Basin. Baltic-Pontic Studies 18: 86-120 .

Ivanova S.V., Klochko V.I., Kośko A., Szmyt M., Toschev G.N., Włodarczak P.

2015 'Yampil inspirations' in the study of the Dniester cultural contact area at the frontier of Pontic and Baltic drainage basins. In: A. Kośko (Ed.). Podolia as a Cultural Contact Area in the 4th/3rd-2nd Millennium BC. BalticPontic Studies 20: 406-424.

Ivanova S.V., Ostroverkhov A.S., Savelev O.K., Ostapenko P.V.

2012 Ocherki istorii i arkheologii Dnestro-Bugskogo mezhdurechia. Kyiv. 
Ivanova S.V., Petrenko V.G., Vetchinnikova N.E.

2005 Kurgany drevnikh skotovodov mezhdurechia Yuzhnogo Buga i Dnestra. Odessa.

Ivanova S.V., Savelev O.K.

2011 Kurgan bilya s. Sichavka Odeskoyi oblasti. Arkheolohiya 3: 70-82.

Ivanova S.V., Tsimidanov V.V.

1993 O sotsiologicheskoy interpretatsii pogrebeniy s povozkami yamnoy kulturno-istoricheskoy obschnosti. Arkheologicheskiy almankh 2: 23-34.

Iwanowa S., Kośko A., Włodarczak P.

2014 Komponent tradycji kultur ceramiki sznurowej. Amfory w północno-zachodnio-nadczarnomorskich grobach kultury jamowej. In: A. Kośko, M. Potupczyk, S. Razumow (Eds) Naddniestrzańskie kompleksy cmentarzysk kurhanowych społeczności z III i z pierwszej połowy II tysiaclecia przed Chr. w okolicach Jampola, obwód winnicki. Archaeologia Bimaris - Monografie 6, 351-386. Poznań.

Kaiser E.

2003 Studien zur Katakombengrabkultur zwischen Dnepr und Prut. Archeologie in Eurasien 14. Mainz am Rhein.

Kashuba M.T., Kurchatov S.I., Scherbakova T.A.

2001-2002 Kochevniki na zapadnoy granitse Velikoy stepi (po materialam kurganov u s. Mocra). Stratum plus 4: 180-252.

Ketraru N.A., Nikolaeva N.A., Podolskiy N.L., Safronov V.A.

1975 Kurgany u s. Starye Kukoneshty Edinetskogo rayona MSSR. Arheologicheskie otkrytiya (1974 g.): 438.

Klein L.S.

1975 Retsenziya na: Kurgany stepnoy chasti mezdurechia Dunaya i Dnestra. Materialy po arkheologii Severnogo Prichernomoria 6, Odessa. Sovetskaya arkheologiya 1: 297-304.

1991 Arkheologicheskaya tipologiya. Leningrad.

Klochko V.I.

2006 Ozbroennia ta viyskova sprava davnoho naselennia Ukrayiny. Kyiv.

Kloczko V.I., Kośko A.

2013 The Baltic Drainage basin in the reconstruction of the mental map of Central Europe held in common by Northern-Pontic Early-Bronze civilization communities: 3200-1600 BC. An outline of the research programme. 
In: A. Kośko (Ed.) The Ingul-Donets Early Bronze Age Civilization as Springboard for Transmission of Pontic Cultural Patterns to the Baltic Drainage Basin. Baltic-Pontic Studies 18: 9-20.

Klochko V.I., Kośko A.,Potupchyk M.V., Włodarczak P.,Żurkiewicz D. Ivanova S.V. 2015 Tripolye (Gordineşti group), Yamnaya and Catacomb culture cemeteries, Prydnistryanske, site 1, Yampil Region, Vinnitsa Oblast: an archaeometric and chronometric description and a taxonomic and topogenetic discussion. In: A. Kośko (Ed.) Podolia as a Cultural Contact Area in the 4th/3rd-2nd Millennium BC. Baltic-Pontic Studies 20: 183-255.

Klochko V.I., Kośko A., Razumov S.M., Włodarczak P., Żurkiewicz D.

2015a Eneolithic, Yamnaya and Noua culture cemeteries from the first half of the 3rd and the middle of the 2nd millennium BC, Porohy, site 3A, Yampil Region, Vinnitsa Oblast: archaeometric and chronometric description, ritual and taxonomic-topogenetic identification. In: A. Kośko (Ed.) Podolia as a Cultural Contact Area in the 4th/3rd-2nd Millennium BC. Baltic-Pontic Studies 20: 78-141.

2015b Eneolithic, Babyno and Noua culture cemeteries, Klembivka, site 1, Yampil Region, Vinnitsa Oblast: archaeometry, taxonomy and topogenetics. In: A. Kośko (Ed.) Podolia as a Cultural Contact Area in the 4th/3rd-2nd Millennium BC. Baltic-Pontic Studies 20: 142-182.

Kośko A.

2000 From research into the issue of the development dependencies of the Cor-ded Ware culture and Yamnaya culture In: S. Kadrow (Ed.) A Turning of Ages / Im Wandel der Zeiten. Jubilee Book Dedicated to Professor Jan Machnik on His 70th Anniversary, 337-346. Kraków.

2014 Traits of "Early Bronze" Pontic Cultures in the development of Lowland and Eastern European forest cultural environment in the Baltic southern drainage basin. An outline of the state of research. In A. Kośko (Ed.) Reception Zones of "Early Bronze Age" Pontic Cultures Traditions: Baltic Basin - Baltic and Black Sea Drainage Borderlands, 4/3 mil. to first half 2 mil. BC. Baltic-Pontic Studies 19: 53-73.

Kośko A., Klochko V.I., Olszewski A.

2012 Ritualniy obiekt naselennia prichornomorskoyi kulturnoyi spilnoty doby rannoyi bronzy na r. Sian, Arkheolohiya 2: 67-75.

Kośko A., Potupczyk M., Razumow S. (Eds)

2014 Naddniestrzańskie kompleksy cmentarzysk kurhanowych społeczności z III $i$ z pierwszej połowy II tysiaclecia przed Chr. w okolicach Jampola, obwód winnicki. Archaeologia Bimaris - Monografie 6. Poznań. 
Kovaleva I.F.

1978 Pogrebeniya zhyvotilovskogo tipa v Prisamarie. In: I. Kovaleva (Ed.), Kurgannye drevnosti stepnogo Podneprovia III-I tys. do n.e., 46-49. Dnepropetrovsk.

1991 Pogrebeniya s maykopskim inventarem v levoberezhe Dnepra (k vydeleniyu zhyvotilovskogo kulturnogo tipa). In: Problemy arkheologii Podneprovia, 69-88. Dnepropetrovsk.

$2002 \mathrm{~K}$ vydeleniyo territorialnykh grupp $\mathrm{v}$ postmariupolskoy kulture. In: R.M. Munchaev, N.Ya. Merpert (Eds) Problemy arkheologii Evrazii, 51-67. Moskva.

Kurchatov S.

2006 Issledovanie kurganov epokhi bronzy na Srednem Prute. Revista Arheologică. Serie nouă 2(1-2): 263-292.

Larina O.V.

1989 Novye kurgannye materialy eneolita-ranney bronzy na Srednem Prute. In: Archeologicheskie issledovaniya v Moldavii (1989 g.), 61 -78. Kishinev.

2003 Pozdnetripolskoe pogrebenie gordineshtskogo tipa na Dnestre. In: E. Sava (Ed.) Interferenţe cultural-chronologice în spaţiul nord-pontic, 57-80. Chişinău.

Larina O., Manzura I., Khakheu V.

2008 Brevichenskiye kurgany. Kishinev.

Leviţki O., Demcenko T.

1994 Grupul tumular de la Corjeuţi-Briceni (R. Moldova). Memoria antiquitatis 19: 213-233.

Leviţki O., Manzura I., Demcenko T.

1996 Necropola tumulara de la Sareteni. Bucureşti.

Levinskiy A.N. Tentiuk I.S.

1990 Issledovanie kurganov u s. Mierkulesht. In: Issledovaniya molodykh uchenykh Moldavii, 93-100. Kishinev.

Lysenko S.D., Razumov S.M.

2014 K voprosu o kontaktakh naseleniya Nizhnego i Srednego Podnestrovia v pervoy polovine II tys. do n.e. Rusin 2 (36): 8-27.

Lytvynenko R.O.

2009 Kulturne kolo Babyne (za materialamy pokhovalnykh pamiatok). Avtoreferat na zdobuttia stupenia doktora istorychnykh nauk. Kyiv.

2006 Pokhovannia kulturnoho kola Babiyne z metalevymy nozhamy. Donetskiy arkheologicheskiy sbornik 12: 32-61. 
Machnik J.

1960 Zabytki z kurhanów kultury ceramiki sznurowej w Wiktorowie (USSR). Materiały Archeologiczne 2: 69-72.

Mantu C.-M.

1998 Cultura Cucuteni. Evolufie, cronologie, legături. Bibliotheca Memoriae Antiquitatis V. Piatra Neamts.

Manzura I.V.

2010 „Vytianutye” pogrebeniya epokhi eneolita v Karpato-Dnestrovskom Regione. Tyragetia. Serie nouă IV(1): 35-47.

2013 Kultury stepnogo eneolita. In: S. Hansen, J. Chochorowski, S.D. Kryzhytskiy, G.Y. Ivakin (Eds) Drevniye kultury Severo-Zapadnogo Prichernomoria, 115-153. Odessa.

Manzura I.V., Dergachev V.A.

1991 Pogrebalnye kompleksy pozdnego Tripolia. Svod istochnikov. Kishinev.

Manzura I.V., Klochko E.O, Savva E.N.

1992 Kamenskie kurgany. Kishinev.

Manzura I.V., Telnov N.P.

1992 Problema pozdnetripolskogo obriada lesostepnoy zony DnestrovskoKarpatskikh zemel (nekotorye itogi i perspektivy izucheniya). In: V.I. Grosu (Ed.) Materialy i issledovaniya po arkheologii $i$ etnografii Moldovy, 118-130. Kishinev.

Merpert N.Y.

1974 Drevneishie skotovody Volgo-Uralskogo mezhdurechia. Moskva.

Movsha T.G.

1964 Trypilske pokhovannia v s. Tsviklivtsi. Arkheolohiya XVI: 213-222.

1971 O severnoy gruppe pozdnetripolskikh pamiatnikov. Sovetskaya Arkheologiya 5: 31-54.

Nikolova A.V., Rassamakin Y.Y.

1985 O pozdnetripolskikh pamiatnikakh Pravoberezhia Dnepra. Sovetskaya Arkheologia 3: 37-56.

Nikulitsa A.

2009 Yuvelirnye izdeliya iz zolota i serebra, obnaruzhennye pri raskopkakh pamiatnikov epokh eneolita i bronzy (po materialam fondov NM AIM). Tyragetia. Serie nouă III [XVIII], nr 1: 157-168.

Okhrimenko G., Skliarenko N., Lokaychuk S.

2012 Okremi pytannia babinskoyi kultury na Volyni. Volyno-Podilski arkheolohichni studiyi 3: 2-12. 
Otroschenko V.V., Rassamakin Y.Y., Chernykh L.A.

2008 Doba bronzy na terenakh Ukrayiny. In: P.P. Tolochko et al. (Eds) Ukrayina. Khronolohiya rozvytku, vol. I., 219-331. Kyiv.

Pâslaru I.

2006 Cultura Delacău-Babino. Mangalia.

Patokova E.F., Petrenko V.G., Burdo N.B., Polischuk L.Y.

1989 Pamiatniki tripolskoy kultury Severo-Zapadnogo Prichernomoria. Kyiv.

Petrenko V.G.

1991 Kurgan bronzovogo veka u s. Starye Beliary. In: V.P. Vanchugov, A.G. Zaginailo, V.G. Kushnir, V.G. Petrenko (Eds), Voronovka II. Poseleniye pozdnebronzovogo veka $v$ Severo-Zapadnom Prichernomorie, 77-91. Kiev.

2004 Vykhvatynskyi typ. In: Entsyklopedia trypilskoyi tsyvilizatsii, vol. 2, 90-91. Kyiv.

2010 Kurgan epokhi paleometalla na poberezhie Khadzhibeiskogo limana. Materialy po arkheologii Severnogo Prichernomoria 11: 303-368.

2013 Usatovskaya kultura. In: In: S. Hansen, J. Chodorowski, S.D. Kryzhytskiy, G.Y. Ivakin (Eds) Drevnie kultury Severo-Zapadnogo Prichernomoria, 163-210. Odessa.

Petrenko V.G., Kovaliukh N.N.

2003 Novye dannye po radiouglerodnoy khronologii eneolita Severo-Zapadnogo Pricheronomoria. In: Trypilski poselennia-giganty v Ukraiyini. Talianky.

Potupczyk M., Razumow S.

2014 Zgrupowanie cmentarzysk kurhanowych w rejonie jampolskim. In: A. Kośko, M. Potupczyk, S. Razumow (Eds) Naddniestrzańskie kompleksy cmentarzysk kurhanowych społeczności z III i z pierwszej połowy II tysiaclecia przed Chr. w okolicach Jampola, obwód winnicki. Archaeologia Bimaris - Monografie 6, 35-40. Poznań.

Rassamakin Y.Y.

1997 Svit skotariv. In: Davnia istoriya Ukrayiny. vol. 1, 273-301. Kyiv.

2000 Kvitianskaya kultura: istoria i sovremennoe sostoyanie problemy. Stratum plus 2: 117-177.

2002 Aspects of Pontic Steppe Development (4550-3000 BC) in Light of the New Cultural-chronological Model. In: K.V. Boyle, C. Renfrew, M.A. Levine (Eds), Ancient interactions: east and west in Eurasia. 49-73. Cambridge.

2004 Stepy Prychornomoria v konteksti rozvytku pershykh zemlerobskykh suspilstv. Arkheolohiya 2: 3-26.

2009 Novye daty k absoliutnoy khronologii epokhi eneolita stepnogo Pricher- 
nomoria (predvaritelnaya informatsiya). Arkheologicheskiy almanakh 20: 289-296.

2013 Pokhovannia kvitianskoyi kultury v konteksti absoliutnoyi khronolohiyi. Arkheolohiya 4(2013): 17-41.

\section{Razumow S.M.}

2014 Komponent tradycji kultury jamowej. In: A. Kośko, M. Potupczyk, S. Razumow (Eds) Naddniestrzańskie kompleksy cmentarzysk kurhanowych społeczności z III i z pierwszej połowy II tysiaclecia przed Chr. w okolicach Jampola, obwód winnicki. Archaeologia Bimaris - Monografie 6, 341-346. Poznań.

Razumov S.M., Kośko A., Karnaukh E.G.

2012 Doslidzhennia kurhanu bilia s. Porohy Yampilskoho rayonu Vinyytskoy Oblasti (held in the archives of IA NANU). Kyiv.

Razumov S.M., Kośko A., Karnaukh E.G., Manigda O.

2013 Zvit pro robotu spilnoyi ukrayinsko-polskoyi Yampilskoyi arkheolohichnoyi ekspeditsii v 2012 rotsi (held in the archives of IA NANU). Kyiv.

Russev N., Fokeev M., Manzura I.

2013 Kurgan eneolita-bronzy u s. Suvorovo Odesskoy oblasti. Tyragetia. Serie nouă, VII [XXII], nr. 1: 157-162.

Ryzhov S.N.

2001-2002 Pozdnetripolskie pamiatniki Bugo-Dneprovskogo mezhdurechia. Stratum Plus 2: 187-196.

Savva E.N.

1988 Issledovanie kurgana u g. Tiraspola. In: Archeologicheskie issledovaniya v Moldavii v 1983 godu, 44-59. Kishinev.

1992 Kultura mnogovalikovoy keramiki Pruto-Dnestrovskogo mezhdurechia. Kishinev.

Sava E., Agulnikov S.

2003 Contribuţii noi la definirea titlului funerar de tip Sabatinovka. In: Interferenţe cultural-cronologice în Spațiul nord-pontic, 113-138. Chişinău.

Savva E.N., Dergachev V.A.

1984 Raskopki kurganov u s. Medvezha. In: Kurgany v zonakh novostroek Moldavii, 98-108. Kishinev.

Shaposhnikova O.G.

1985 Yamnaya kulturno-istoricheskaya obschnost. In: D.Y. Telegin (Ed.) Arkheologiya Ukrainskoy SSR, vol. I, 336-352. Kyiv. 
Shaposhnikova O.G, Fomenko V.N., Dovzhenko N.D.

1986 Yamnaya kulturno-istoricheskaya Oblast (yuzhnobugskiy variant). Kyiv.

Shmagliy N.M., Chernyakov I.T.

1970 Kurgany stepnoy chasti mezhdurechia Dunaya i Dnestra, Materialy po arkheologii Severnogo Prichernomoria 6, Odessa.

Subbotin L.V.

1985 Semenovskiy mogilnik epokhi eneolita-bronzy. In: Novye materialy po arkheologii Severo-Zapadnogo Prichernomoria, 45-95. Kiev.

1991 O kulturno-khronologicheskom meste drevneyshykh vytianutykh pogrebeniy Budzhakskoy stepi. In: E.V. Yarovoy (Ed.), Drevneyshiye obschnosti zemledeltsev $i$ skotovodov Severnogo Prichernomoria ( $V$ tys. do n.e. $-V$ v. n.e.). Materialy mezdunarodnoy konferentsii 10-14 dekabria 1990 g., 71-72. Tiraspol.

2000 Severo-Zapadnoe Prichernomore v epokhu ranney i sredney bronzy. Stratum Plus 2: 350-387.

2003 Orudiya truda, oruzhie i ukrasheniya yamnoy kultury Severo-Zapadnogo Prichernomoria. Odessa.

Subbotin L.V., Dzigovskiy A.N., Ostroverkhov A.S.

1998 Arkheologicheskie drevnosti Budzhaka. Kurgany u sel Vishnevoe i Belolesie. Odessa.

Subbotin L.V., Fokeev M.M., Sapozhnikov I.V.

1986 Otchet o rabote Dunay-Dnestrovskoy novostroechnoy ekspeditsii IA AN USSR $v 1986$ godu (held in the archive of IA NANU, nr 1986/20). Kiev.

Subbotin L.V., Ostroverkhov A.O., Dzygovskiy A.N.

1995 Arkheologicheskie drevnosti Budzhaka. Kurgany us. Trapovka i Novoselitsa. Odessa.

Subbotin L.V., Sapozhnikov I.V., Subbotin A.V.

2001-2002 Kurgannyi mogilnik Diviziya II v mezhdureche Khadzhidera i Alkalii. Stratum Plus 2: 563-581.

Subbotin L.V., Shmagliy N.M.

1970 Rozkopky kurhannoho mohylnyka v m. Bolhradi Odeskoyi oblasti. Arkheolohiya 24: 123-128.

Sveshnikov I.K.

1990 Kultura mnogovalikovoy keramiki. In: E.A. Balaguri, O.P. Chernykh (Eds) Arkheologiya Prikarpatia, Volyni i Zakarpatia. Eneolit, bronza i rannee zhelezo, 74-76. Kyiv. 
Szmyt M.

1999 Between West and East. Globular Amphorae Culture in Eastern Europe, Baltic-Pontic Studies 8.

Topal D.A., Tserna S.V.

2010 Pozdnetripolskiy mogilnik i poseleniya u s. Kunicha (Floreshtskiy r-n, Respublika Moldova). Stratum plus 2: 281-298.

Toschev G.N.

1987 Sredniy period bronzovogo veka Yugo-Zapada SSSR. (held in the archives of INION AN SSSR.19.06.1987 g., № 29903.). Kyiv.

1991 Zapadnyi areal pamiatnikov katakombnoy kultury. In: Katakombnye kultury Severnogo Prichernomoria, 85-100. Kyiv.

1992 Kurgany epokhi bronzy mezhdurechia Yalpuga i Kaluga. Zaporozhe.

2013 In the West of the Catacomb Area. In: A. Kośko, V.I. Klochko (Eds) The Ingul-Donets Early Bronze Civilization As Springboard For Transmission Of Pontic Cultural Patterns To The Baltic Drainage Basin 3200-1750, Baltic Pontic Studies 18: 72-85.

Varzar A., Pezhemskiy D.

2003 Paleoantropologicheskiy material iz pozdnetripolskogo kompleksa Tetereuke Noue XV. In: E. Sava (Ed.) Interferenţe cultural-cronologice $\hat{\imath}$ spaţiul Nord-Pontic, 81-88. Chişinău.

Vetchinnikova N.E.

1996 Pokhovannia epokhy bronzy z kurhaniv poblyzu s. Strumok Odeskoyi oblasti. Arkheolohiya 1: 141-146.

Videiko M.Y.

1999 Radiocarbon Dating Chronology of the Late Tripolye Culture. In: A. Kośko (Ed.), The Foundations of Radiocarbon Chronology of Cultures Between the Vistula and Dnieper in 3150-1850 BC, Baltic-Pontic Studies 7: 34-71.

2000 Tripolye and the cultures of Central Europe: facts and character of interactions: 4200-2750 BC. In: A. Kośko, V. Klochko (Eds) The Western Border Area of the Tripolye Culture, Baltic-Pontic Studies 9: 13-68.

Włodarczak P.

2006 Kultura ceramiki sznurowej na Wyżynie Małopolskiej. Kraków.

2014 Sekwencja czynności obrzędowych:problem korespondencji tradycji funeralnych kultury jamowej i kultury ceramiki sznurowej na Wyżynie Podolskiej. In: A. Kośko, M. Potupczyk, S. Razumow (Eds) Naddniestrzańskie kompleksy cmentarzysk kurhanowych społeczności z III i z pierwszej połowy II tysiaclecia przed Chr. w okolicach Jampola, obwód winnicki. Archaeologia Bimaris - Monografie 6, 313-340. Poznań. 
Włodarczak P., Klochko V.I., Kośko A., Potupchik M.V.

2015 Zvit pro rozkopky kurhaniv bilia sela Prydnistryanske Yampilskoho rayonu Vinnitskoyi Oblasti u 2014 rotsi (held in the archives of IA NANU). Kyiv.

Yarovoy E.V.

1984 Pogrebalnyi obriad nekotorykh skotovodcheskikh plemen Srednego Pruta (po materialam raskopok kurganov u s. Korpach). In: I.I. Artmenko (Ed.) Kurgany v zone novostroek Moldavii: 37-75. Kishinev.

1990 Kurgany eneolita-bronzy Nizhnego Podnestrovia. Kishinev.

2000 Skotovodcheskie naselenie Severo-Zapadnogo Prichernomoria epokhi rannego metalla. Avtoreferat na soiskanie uchonoy stepeni doktora istoricheskikh nauk. Moskva.

Yarovoy E.V., Tserna S.V., Popovich S.S.

2012 Pozdnetripolskiy mogilnik u s. Oksentia (Dubossarskiy rayon, Respublika Moldova). Stratum plus 2: 287-302.

Zakharuk Y.M.

1971 Pamiatky sofiivskoho typu. In: Arkheolohiya Ukrainskoyi RSR vol. 1. Kyiv.

Zbenovich V.G.

1967 Raskopki kurganov u s. Stavchany Chernovitskoy oblasti. Arkheologicheskie issledovaniya v Ukraine 1: 49-55. 